UNIVERSIDADE DE SÃO PAULO

FACULDADE DE FILOSOFIA, LETRAS E CIÊNCIAS HUMANAS

DEPARTAMENTO DE GEOGRAFIA

PROGRAMA DE PÓS-GRADUAÇÃO EM GEOGRAFIA FíSICA

MURILO ROGÉRIO RODRIGUES

A escassez de água para abastecimento público e seus reflexos socioeconômicos no município de Itu-SP 


\author{
UNIVERSIDADE DE SÃO PAULO \\ FACULDADE DE FILOSOFIA, LETRAS E CIÊNCIAS HUMANAS \\ DEPARTAMENTO DE GEOGRAFIA \\ PROGRAMA DE PÓS-GRADUAÇÃO EM GEOGRAFIA FÍSICA
}

\title{
A escassez de água para abastecimento público e seus reflexos socioeconômicos no município de Itu-SP
}

Murilo Rogério Rodrigues

\begin{abstract}
Dissertação apresentada ao Programa de Pós-Graduação em Geografia Física do Departamento de Geografia da Faculdade de Filosofia, Letras e Ciências Humanas da Universidade de São Paulo, para a obtenção do título de Mestre em Geografia.
\end{abstract}

Orientador: Prof. Dr. Emerson Galvani 


\section{MURILO ROGÉRIO RODRIGUES}

A escassez de água para abastecimento público e seus reflexos socioeconômicos no município de Itu-SP

Dissertação apresentada ao Programa de Pós-Graduação em Geografia Física do Departamento de Geografia da Faculdade de Filosofia, Letras e Ciências Humanas da Universidade de São Paulo, para a obtenção do título de Mestre em Geografia.

Aprovado em:

Banca examinadora

Prof. Dr. João Afonso Zavattini

Instituição: Universidade Estadual Paulista

Assinatura:

Prof. Dr. José Bueno Conti

Instituição: Universidade de São Paulo

Assinatura:

Prof. Dr. Emerson Galvani

Instituição: Universidade de São Paulo

Assinatura: 


\section{AGRADECIMENTOS}

Agradeço a todos que de forma direta ou indireta contribuíram para a realização desta pesquisa, em especial:

- A Deus.

- Aos meus pais José Carlos e Célia pelo incentivo que sempre me deram nos estudos.

- Ao programa de Pós-Graduação em Geografia Física da Faculdade de Filosofia, Letras e Ciências Humanas da Universidade de São Paulo pela oportunidade da realização deste trabalho.

- Ao Prof. Dr. Emerson Galvani pela ajuda, incentivo e amizade nestes três anos de orientação.

- Ao Serviço Autônomo de Água e Esgoto de Itu - SAAE pelo fornecimento de importantes dados e materiais sem os quais a realização desta dissertação ficaria prejudicada.

- À Amanda, pela companhia, pelas alegrias e por todos os momentos felizes durante esse tempo de convivência. 


\section{A escassez de água para abastecimento público e seus reflexos socioeconômicos no município de Itu-SP}

\section{RESUMO}

O município de Itu-SP já foi um dos mais importantes da província de São Paulo, sobretudo entre meados do século XIX e início do século XX. Nesta época ltu tinha grande participação na economia do estado com o cultivo do café, e na vida política do país, pois foi nele que se deu a convenção republicana de 1873. Porém, da metade do século XX em diante, o município passou a enfrentar diversos problemas internos o que atrapalhou o seu desenvolvimento, e acarretou numa diminuição significativa de importância no cenário estadual e nacional. Um desses problemas foi a escassez de água para abastecimento público ao longo de séculos, mas que se intensificou durante o século passado trazendo prejuízos em diversos setores. Este estudo teve por objetivo analisar esta problemática, seus reflexos para o município e para população ituana ao longo das últimas décadas. Os resultados obtidos e aqui apresentados permitiram-nos conhecer a atual situação dos recursos hídricos e do serviço de abastecimento público de água municipal. Revelaram também características peculiares, mostraram a relação existente entre o problema do abastecimento público de água e o quadro socioeconômico ituano como, por exemplo, um aumento dos gastos com saúde e uma menor produção industrial em anos de racionamento.

Palavras-chave: Recursos hídricos, Falta de água, Abastecimento público, Reflexos socioeconômicos, Município de Itu-SP 


\title{
The shortage of water for public supplyng and it socioeconomics reflections in the municipality of Itu-SP
}

\begin{abstract}
The municipality of Itu-SP was already one of the most important districts of São Paulo province, above all between the nineteenth century and the turn of the twentieth century. At this time Itu had great participation in the state economy with the coffee cultivation, and the political life of the country, because it was in Itu that the republican convention of 1873 took place. However, from the mid twentieth century on, the municipality started facing several internal problems that hindered its development, and it brought about a significant decrease of importance in the state and national scenery. One of these problems was the water shortage for public supply along centuries, which was intensified during the last century resulting losses in several sectors. This case study had the objective to analyze this problem, its reflections on the municipality and on Itu population along the last decades. The obtained results and presented here allowed us to know today's situation of the hydric resources and the municipal water supply public service. They also revealed peculiar characteristics, they showed the existent relationship between the problem of the public water supply and Itu's socioeconomic picture such as, for instance, an increase in health expenses and a smaller industrial production in years of rationing.
\end{abstract}

Keywords: Hydric resources, Lack of water, Public supply, Socioeconomics reflections, Municipality of Itu-SP 


\section{SUMÁRIO}

1 - Introdução ao tema da pesquisa..

2 - Justificativa da escolha do tema e do município de estudo. .18

3 - Objetivo geral, objetivos específicos e hipótese.

4 - Metodologia e procedimentos técnico-operacionais

5 - Caracterização da área de estudo

5.1 - Situação Geográfica do Município de Itu-SP..............................................24

5.2 - Aspectos Históricos: Origem e Evolução do Núcleo Urbano de Itu................24

6 - Caracterização físico-natural do município de Itu-SP..............................................30

7 - Caracterização socioeconômica do município de Itu-SP....................................44

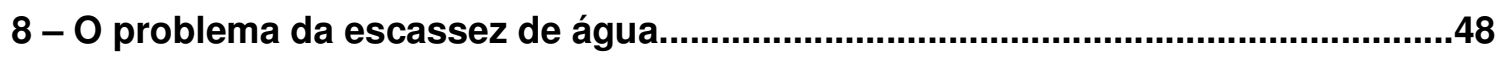

9 - Aspectos Técnicos: Captação, Tratamento e Distribuição de água em

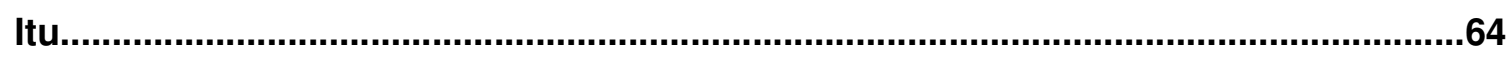

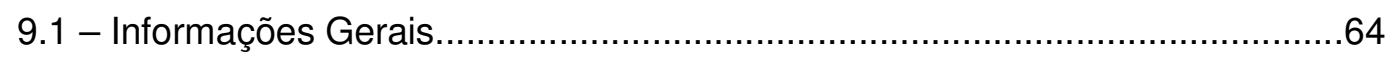

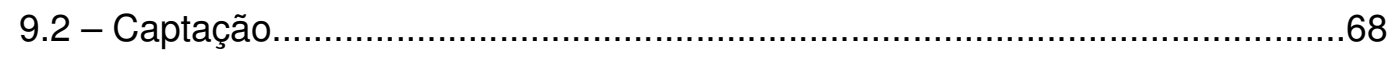

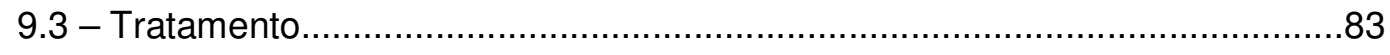

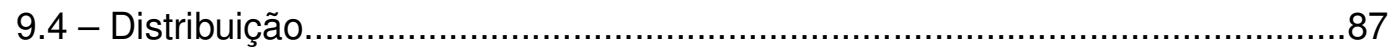

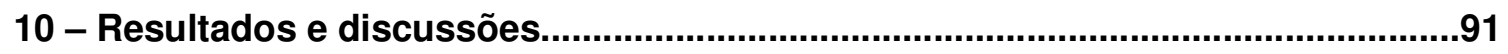

10.1 - Os reflexos socioeconômicos da escassez de água no município de Itu-SP. 
10.1.1 - Reflexos da falta de água para abastecimento público na economia Ituana (Indústria e comércio)...............................................91

10.1.2 - Reflexos sociais da falta de água para abastecimento público no município de Itu-SP.

11 - Configurações finais

12 - Referências Bibliográficas. 126

13 - Anexos .131

\section{Lista de Figuras}

Figura 1 - Mapa da localização do município de Itu no estado de São Paulo........ 15

Figura 2 - Decreto municipal no 3546 de expansão do perímetro urbano de ItuSP. 28

Figura 3 - Seção geológica-geomorfológica esquemática do estado de São Paulo destacando a localização do município de ltu .30

Figura 4 - Unidades geomorfológicas do município de Itu-SP. .32

Figura 5 - Unidades geológicas do município de Itu-SP. .33

Figura 6 - Aspectos gerais do Varvito. As camadas horizontais indicam a alternância de sazonalidades ocorrida no Pleistoceno. .34

Figura 7 - Principais áreas de exploração de argila e granito no município de ItuSP. 
Figura 8 - Principais cursos de água do município de Itu-SP.

Figura 9 - Documento do SAAE confirmando a aplicação da multa de $R \$ 141,71$ para quem fosse flagrado desperdiçando água em 2000.

Figura 10 - A topografia na região de Itu-SP. .58

Figura 11 - A pluviosidade média na região de Itu no período de 1967 -1997. 59

Figura 12 - Destino do volume total de água produzido no município de Itu-SP. 62

Figura 13 - Índices de atendimento urbano, cobertura municipal e hidrometração no município de Itu-SP. .66

Figura 14 - Barragem de acumulação do Taquaral com níveis mínimos no dia $3 / 11 / 07$ 70

Figura 15 - Barragem de acumulação do Taquaral com níveis mínimos no dia $3 / 11 / 07$ 71

Figura 16 - Barragem de acumulação do Taquaral com níveis mínimos no dia 3/11/07. 71

Figura 17 - Barragem de acumulação do Taquaral com níveis mínimos no dia 3/11/07 .72

Figura 18 - Barragem de acumulação do Taquaral com níveis mínimos no dia 3/11/07. .72

Figura 19 - Barragem de acumulação do Taquaral com volume de armazenamento máximo no dia 6/11/07. .73

Figura 20 - Barragem de acumulação do Taquaral com volume de armazenamento máximo no dia 6/11/07. 
Figura 21 - Barragem de acumulação do Taquaral com volume de armazenamento

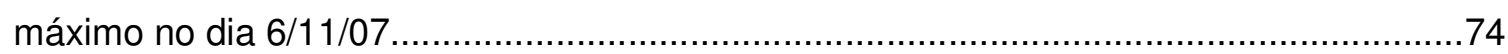

Figura 22 - Barragem de acumulação do Taquaral com volume de armazenamento máximo no dia 6/11/07. .75

Figura 23 - Barragem de acumulação do Taquaral com volume de armazenamento máximo no dia 6/11/07 75

Figura 24 - Barragem de captação do Itaim com volume de armazenamento reduzido no dia $3 / 11 / 07$ 76

Figura 25 - Barragem de captação do Itaim com volume de armazenamento reduzido no dia $3 / 11 / 07$. 77

Figura 26 - Barragem de captação do Itaim com volume de armazenamento reduzido no dia $3 / 11 / 07$ 78

Figura 27 - Barragem de captação do Itaim com volume de armazenamento reduzido no dia $3 / 11 / 07$ .78

Figura 28 - Placa indicando o início e o término das últimas obras de recuperação e desassoreamento realizadas na barragem de captação do Itaim.

Figura 29 - Sistema de distribuição de água no núcleo urbano principal de ItuSP 88

Figura 30 - Sistema de distribuição de água no núcleo urbano secundário do Pirapitingui. .90

Figura 31 - Evolução do número de estabelecimentos industriais em \% em Itu, Sorocaba, Salto, Indaiatuba e Cabreúva entre 1991 - 2005. 101 
Figura 32 - Evolução relativa do número de estabelecimentos industriais em Itu, Sorocaba, Salto, Indaiatuba e Cabreúva entre 1991 - 2005........................................102

Figura 33 - Evolução da participação dos municípios de Itu, Sorocaba, Salto, Indaiatuba e Cabreúva no número de estabelecimentos industriais em \% entre 1991 - 2005. 104

Figura 34 - Evolução relativa da participação dos municípios de Itu, Sorocaba, Salto, Indaiatuba e Cabreúva no número de estabelecimentos industriais entre 1991 2005.

Figura 35 - Volume consumido pela categoria residencial entre os anos de 1997 e 2006. 108

Figura 36 - Volume consumido pela categoria comercial entre os anos de 1997 e 2006. 109

Figura 37 - Volume consumido pela categoria Industrial entre os anos de 1997 e 2006.

Figura 38 - Faturamento do SAAE na categoria residencial entre os anos de 1997 e 2006.

Figura 39 - Faturamento do SAAE na categoria comercial entre os anos de 1997 e 2006.

Figura 40 - Faturamento do SAAE na categoria industrial entre os anos de 1997 e 2006 .

Figura 41 - Evolução do PIB do município de Itu em milhões de reais entre os anos de 1999 e 2004 116

Figura 42 - Total da participação do município de Itu na receita do Estado de São Paulo em reais entre os anos de 1997 e 2003. 
Figura 43 - Total de despesas do município de ltu em saúde entre 1990 - 2003 120

\section{Lista de Quadros}

Quadro 1 - Panorama geral das 14 microbacias do município de Itu-SP

Quadro 2 - Informações gerais sobre o sistema de captação, tratamento e distribuição de água do município de Itu-SP

67

Quadro 3 - Mananciais utilizados para abastecimento público no núcleo urbano principal de Itu-SP. 68

Quadro 4 - Manancial utilizado para abastecimento público no núcleo urbano secundário do Pirapitingui em Itu-SP. .79

Quadro 5 - Mananciais passíveis de aproveitamento no município de Itu-SP .80

Quadro 6 - Total de poços da prefeitura no município de Itu-SP. .81

Quadro 7 - Características dos processos de tratamento de água da ETA I (Rancho Grande). 84

\section{Lista de Tabelas}

Tabela 1 - Evolução da população urbana, rural e total do município de Itu entre 1970 2006. 
Tabela 2 - Evolução do número bruto, total geral e crescimento em \% do número de estabelecimentos Industriais de Itu, Sorocaba, Salto, Indaiatuba e Cabreúva entre 1991 2005.

Tabela 3 - Evolução em \% da participação dos municípios de Itu, Sorocaba, Salto, Indaiatuba e Cabreúva no número de estabelecimentos Industriais entre 1991 2005. 103

\section{Anexos}

Anexo 1 - Reportagens acerca do problema da falta de água ocorrido no município de ItuSP no ano 2000 131

Anexo 2 - Reportagens acerca do problema da falta de água ocorrido no município de ItuSP no ano de 2007. 144

Anexo 3 - Mapa hidrográfico do município de Itu-SP (em CD). .149

Anexo 4 - Planta com as instalações do SAAE de Itu (em CD). 149 


\section{1 - Introdução ao tema da pesquisa}

A Estância Turística de Itu se localiza a sudeste do estado de São Paulo, dentro da sub-região de Sorocaba, próximo a cidades importantes como Sorocaba (35 km), Campinas $(47 \mathrm{~km})$ e São Paulo $(92 \mathrm{~km})$, e também próximo a relevantes rodovias do estado como a Castello Branco (SP-280), Marechal Rondon (SP-300) e a Rodovia do Açúcar (SP-308) (Figura 1). Foi uns dos primeiros núcleos urbanos do interior paulista, sua fundação data de 1610 em plena época das bandeiras que saíam de São Paulo de Piratininga margeando o Rio Tietê, rumo ao "Sertão" em busca de mão de obra indígena.

Inicialmente as terras onde hoje se localiza o núcleo urbano de Itu foram doadas pelos portugueses ao bandeirante Domingos Fernandes e ao seu genro Cristóvan Diniz que criaram o povoado e, posteriormente, a elevaram a condição de freguesia em 1653. Nesta época o povoado servia de entreposto para os bandeirantes que seguiam para o Oeste.

Em 1657 foi elevado a vila, mas somente por volta de 1780 Itu passou a ter outras atividades econômicas não relacionadas as bandeiras, a mais importante neste período foi o cultivo da cana-de-açúcar. Em 1822 recebe do Imperador Dom Pedro I o título de "A Fidelíssima" por sua posição a favor da independência. Em 1842 foi elevada a condição de cidade.

Durante décadas, Itu foi considerado o município mais rico da província de São Paulo, com importante participação na vida política e econômica sobretudo no final do século XIX e começo do século XX com o cultivo do café. O município se desenvolveu muito nesta fase, tornando-se um dos mais importantes do estado de São Paulo, porém, 
a partir da metade do século $\mathrm{XX}$, passou a perder importância no cenário nacional e estadual enfrentando atualmente uma estagnação no seu desenvolvimento, sobretudo econômico.

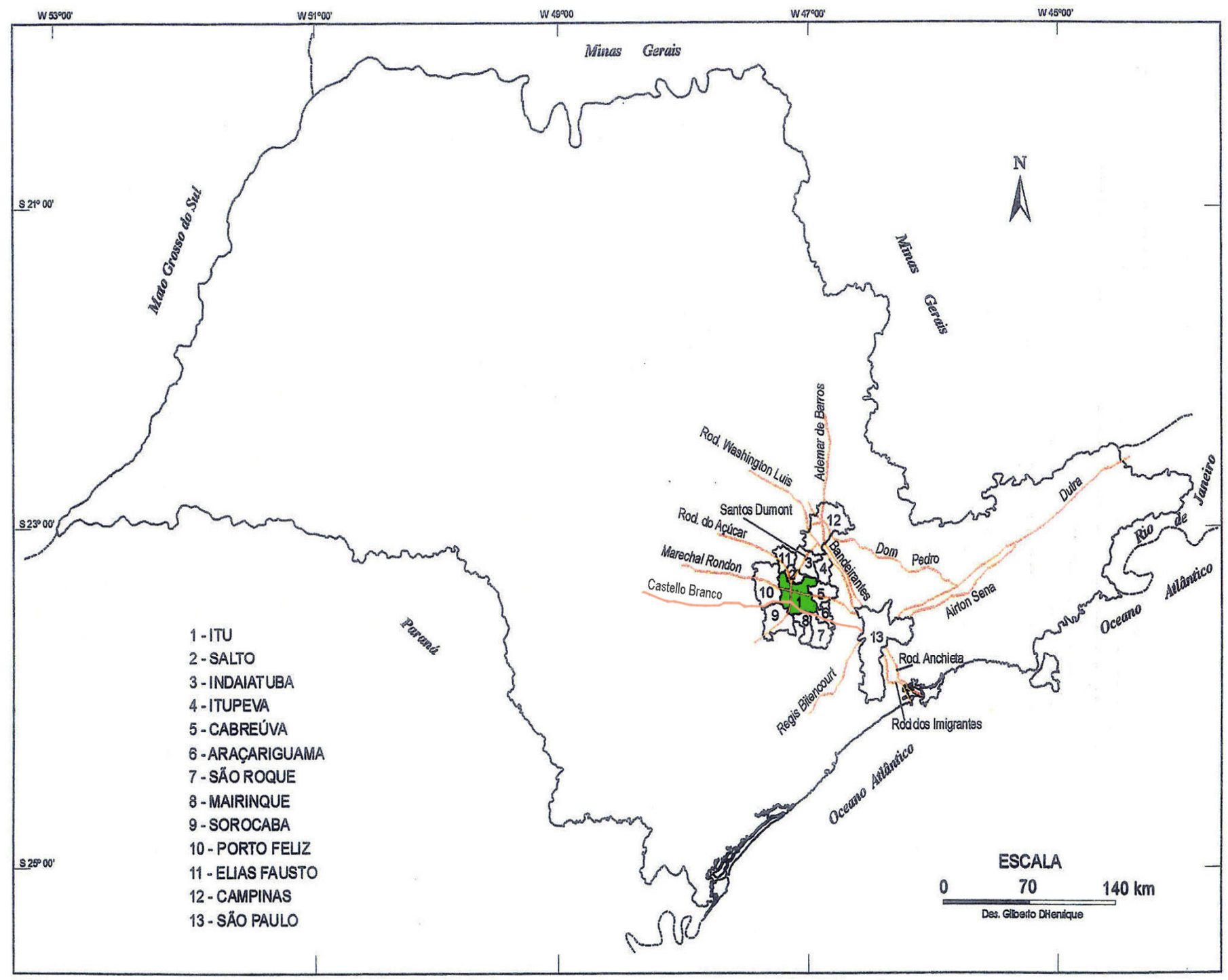

Figura 1 - Mapa da localização do município de Itu no estado de São Paulo. Fonte: Rodrigues, 2003. 
Vários são os acontecimentos considerados como possíveis causadores ou maximizadores deste quadro, e dentre todas as hipóteses, podemos mencionar, por exemplo, o problema da falta de água para abastecimento público. Este foi um dos primeiros a afetar a vila Ituana, como podemos comprovar numa passagem contida no livro intitulado "A cidade de Itu" de autoria do historiador ituano Francisco Nardy Filho.

Dous ribeiros que marginam as encostas da suave colina (...) serviam para abastecer de água a população (...) porém, o desenvolvimento da população, que ia se estendendo pela parte mais alta do lugar, veio, aos poucos, trazendo para a população a falta de água no início de 1800 (...). (NARDY FILHO, 1999, vol.1, p.209).

Além de não ter sido solucionado logo de início, o problema tornou-se costumeiro na vida da população ituana durante praticamente todo o século XIX, houve períodos melhores e piores de acordo com fatores naturais e antrópicos estritamente relacionados à questão como as condições climáticas:

Em 1877, devido a secca havida esse anno, mais se agravou a falta de água, vindo até faltar bebedouros para os animaes e logar para a lavagem de roupa (...). (NARDY FILHO, 1999, vol.1, p.219).

Até a metade do século $\mathrm{XX}$ a população ituana aumentou razoavelmente, porém num ritmo considerado normal em relação à média geral dos municípios paulistas com características semelhantes a este. Mas após a década de 1960, acompanhando o 
processo de crescimento acelerado da região que recebia a cada ano um contingente maior de atividades industriais e comerciais devido à adoção de uma política de desenvolvimento econômico e geração de empregos, a população de Itu começa a crescer consideravelmente e de forma acelerada. Desde a década de 1970 até o final da década de 1990 aumentou $275 \%$ e, com ela, se intensificaram diversos problemas, o principal deles foi a falta de água. Durante muitos anos a cidade enfrentou situações extremamente difíceis, sobretudo, no final dos anos de 1990, início de 2000 , os mais críticos foram os de 1999, 2000 e 2001 quando a cidade entrou em colapso ocasionado pela falta de água para abastecimento urbano, e decretou inclusive estado de calamidade pública. Neste período os racionamentos foram constantes e severos, setores importantes, como indústrias e o comércio, até os setores mais essenciais e vitais, como escolas e hospitais, ficaram sem este importante recurso tendo que recorrer a doações de particulares e a ajuda estadual e federal.

Fica evidente a gravidade do assunto e principalmente a necessidade de se fazer estudos sobre esta questão, já que poucos foram os trabalhos até agora realizados sobre tal temática. Somente a partir de dados científicos concretos é que se poderá traçar itinerários para resolver a curto, médio e longo prazo o problema. É pensando nisso que nos propusemos a elaborar esta pesquisa, uma análise sobre os recursos hídricos, o serviço de abastecimento público de água, a escassez do recurso e os reflexos socioeconômicos para o município de Itu sobretudo nas últimas décadas. 


\section{2 - Justificativa da escolha do tema e do município de estudo}

O elemento água é um dos mais importantes recursos naturais existentes, ele é vital para qualquer tipo de ser. Desta forma deve ser conservado e utilizado de maneira sustentável evitando assim sua escassez. Tundisi et al (2003) diz que:

A conservação dos recursos hídricos é também outro aspecto fundamental (...) A conservação de mananciais e de fontes de água subterrâneas deve fazer parte de um processo contínuo e de uma atitude permanente. (p. 194).

Segundo REBOUÇAS et al (1999), todos os países em desenvolvimento devem adotar políticas integradas de gerenciamento de recursos hídricos, pois sem um plano imediato de ações que visem administrar de forma coerente estes recursos, muitos destes países certamente terão graves problemas relacionados à falta de água num futuro muito próximo.

A escolha do município de Itu-SP se deve por historicamente estar associado a problemas relacionados aos recursos hídricos, principalmente no que diz respeito ao abastecimento público de água. O Autor desta dissertação é natural e reside até hoje no mesmo. Desde pequeno enfrentou os problemas referentes à falta de água, viveu repetidamente os racionamentos crônicos e todas as dificuldades decorrentes deste, bem como grande parte da população ituana. Durante todo o seu crescimento acompanhou os fatos ocorridos no município relacionados a este tema por vivenciá-los cotidianamente e por interesse próprio, já que o assunto sempre o intrigou. 
Sua inquietação sempre foi grande principalmente pelo problema ser tão antigo e nunca ter sido solucionado, aliás, nem as principais causas eram colocadas de forma clara pelo poder público municipal. A Temática sempre foi considerada de suma importância pelo autor desta dissertação, e foi uma das principais responsáveis pela escolha da ciência geográfica como carreira e área de atuação.

O primeiro estudo realizado abordando o assunto foi em 2003, com a elaboração do trabalho de conclusão de curso (TCC) para a obtenção do título de bacharel em Geografia no ano supra citado, na Universidade Estadual Paulista "Júlio de Mesquita Filho" - Unesp - campus de Rio Claro-SP. Na ocasião, a pesquisa intitulada: "O problema do abastecimento público de água em Itu: uma abordagem geográfica com ênfase nos aspectos climatológicos" foi uma tentativa de encontrar as principais causas do problema da falta de água no município em questão. Os procedimentos e resultados deste estudo serão abordados mais adiante. 


\section{3 - Objetivo geral, objetivos específicos e hipótese}

O objetivo do trabalho proposto é estudar o problema da escassez de água para abastecimento público, bem como seus reflexos socioeconômicos para o município de ltuSP sobretudo nas últimas décadas. Esta análise dar-se-á por intermédio de uma pesquisa que englobe fatores físicos e humanos. Nesta pesquisa será utilizado o arcabouço teórico e prático das áreas que formam a ciência geográfica, sobretudo aquelas diretamente relacionadas ao tema em questão como por exemplo: hidrografia, climatologia, demografia e geografia econômica.

Vários aspectos que serão abordados como objetivos específicos darão suporte para a elaboração do trabalho ora proposto, são eles: histórico do problema da falta de água no município ao longo do tempo enfocando sobretudo as últimas décadas, situação dos recursos hídricos do município de Itu, aspectos técnicos do Serviço Autônomo de Água e Esgoto de Itu (SAAE) e situação socioeconômica histórica e atual do município.

Como objetivo final, a confecção de um documento que poderá comprovar ou rechaçar a hipótese proposta pelo autor de que a falta de água para abastecimento público, é um grande inibidor do desenvolvimento socioeconômico municipal. Ao término desta pesquisa espera-se ter como resultado um estudo com informações que nos permitirão obter conclusões sobre a relação existente entre a problemática da falta de água e a situação socioeconômica histórica e atual do município de Itu-SP. 


\section{4 - Metodologia e procedimentos técnico-operacionais}

Há muito tempo a Geografia convive com a dicotomia entre Geografia Física x Geografia Humana. Muitas foram as discussões e considerações feitas sobre este tema pelos profissionais da área. Na maioria das vezes essa discussão gera problemas e controvérsias, como por exemplo, confrontos pessoais nos quais a parte mais prejudicada é a Ciência Geográfica. Essa prática deve ser superada, pois não existe motivo para tal divisão, ou seja, não se pode fazer uma abordagem que separa o quadro natural do quadro social nesta pesquisa.

A Geografia tem como um dos seus principais valores a visão "integrada" dos elementos que a compõe. Ela deve possibilitar uma visão global dos fenômenos que se assentam no espaço geográfico e, por conseguinte, uma visão crítica da realidade. Caso contrário estará fadada a ter parte de seu conteúdo incorporado por outras ciências, como nos casos dos relacionados ao quadro físico/natural, que são incorporados a outras áreas e outras ciências como a Geologia, a Meteorologia a Biologia entre outras.

A presente dissertação caminha por este viés, ela não se enquadra em uma área específica da Ciência Geográfica, mas em várias, pois utiliza a todo o momento conteúdos referentes à parte física e à parte humana da Geografia. A idéia é buscar sempre uma análise integrada dos fatos que possibilite um entendimento real e completo do problema em foco e de suas particularidades. O estudo da relação existente entre a sociedade e a natureza no município de Itu também é importante principalmente na zona urbana, pois seu espaço urbano apresenta inúmeras questões a serem esclarecidas.

Faz-se necessária uma completa análise dos fatores naturais e antrópicos de Itu. É preciso analisar documentos históricos e levantamentos geográficos, na tentativa de 
identificar aspectos importantes que podem esclarecer questões relevantes ainda sem respostas claras, como por exemplo, quando realmente se iniciou o problema da falta de água, como ele evoluiu, e o porquê ainda não foi solucionado.

$\mathrm{Na}$ literatura é difícil encontrar trabalhos que possuam características e objetivos semelhantes ao desta dissertação para servirem como bases metodológicas. Ribeiro (1975) estudou o serviço de abastecimento público, o consumo e a demanda de água do município de Bauru-SP na tentativa de elaborar subsídios à demanda do recurso de acordo com o tempo meteorológico. Este estudo teve objetivo diferente do proposto na presente dissertação, mas por estudar as características do serviço de água do município de Bauru bem como o consumo e a demanda, foi utilizado no auxílio da análise destes fatores em Itu.

$\mathrm{Na}$ caracterização da área de estudo foram utilizados mapas de localização, geológicos, geomorfológicos, hidrológicos e climatológicos do município e da região, além de materiais como livros e apostilas que tragam informações históricas sobre Itu. Também foi utilizado um arquivo com reportagens de jornais que trata exclusivamente dos assuntos e acontecimentos relacionados aos recursos hídricos e, principalmente, à falta de água para abastecimento público no município, em especial nas últimas décadas.

No decorrer da pesquisa foram usados diversos materiais tais como: computador, disquetes, Cd's, impressora, além de caderneta de campo e gravador para algumas entrevistas, bem como, na medida das necessidades, diversos programas de computador do tipo World, Excel, Corew Draw, AutoCad etc. Parte de todo este material é de propriedade do autor da presente dissertação e parte foi fornecida pela prefeitura e pelo Serviço Autônomo de Água e Esgoto (S.A.A.E) locais. O material é composto por apostilas, livros e mapas contendo informações gerais sobre o município e sobre os 

socioeconômicos no município de Itu-SP.

serviços municipais oferecidos pelo poder público, sobretudo o de abastecimento de água. 


\section{5 - Caracterização da área de estudo}

\subsection{Situação geográfica do município de Itu-SP}

O município de Itu-SP possui uma área de $642 \mathrm{~km}^{2}$ e seu marco topográfico, localizado no "Cruzeiro" (ponto a partir do qual a cidade desenvolveu-se), possui as

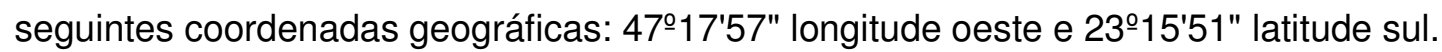

Ele está inserido no eixo São Paulo - Campinas - Sorocaba, distando aproximadamente $100 \mathrm{~km}$ da capital São Paulo e $45 \mathrm{~km}$ da cidade de Sorocaba. As suas principais vias de acesso são: a Rodovia Marechal Rondon (SP-300), Rodovia do Açúcar (SP-308), Rodovia Santos Dumont (SP-075) e Rodovia Presidente Castello Branco (SP280).

O município de Itu faz divisa ao norte com os municípios de Salto e Indaiatuba, a nordeste com Itupeva, a leste com Cabreúva, a sudeste com Araçariguama, a sul com São Roque e Mairinque, a sudoeste com Sorocaba, a oeste com Porto Feliz e a noroeste com Elias Fausto (Figura 1). Apresenta altitude média de 600 metros, porém, há lugares na zona limítrofe deste município com os de São Roque e Cabreúva em que a altitude chega a 1000 metros.

\section{2 - Aspectos históricos: origem e evolução do núcleo urbano de Itu}

Os primeiros relatos de que se tem notícia sobre a cidade de Itu dão conta de que antes mesmo dos portugueses chegarem ao Brasil, existia um povoamento indígena da tribo dos Carijós no local onde hoje se situa a cidade em questão. Estes nativos migraram 
para o interior do estado por volta do ano de 1560, pois estavam sendo perseguidos pelos bandeirantes que partiam de São Paulo e vinham margeando o rio Tietê em busca de mão de obra indígena. Neste caminho que percorriam, os bandeirantes fundavam pequenos lugarejos que os abrigavam e serviam de apoio para as expedições que se seguiam, rumo ao "Sertão" do estado. Desta forma foram fundadas várias cidades, dentre as quais podemos citar: Santana do Parnaíba, Bom Jesus de Pirapora, Itu e Porto Feliz.

Segundo dados históricos existiu um importante sertanista chamado Manuel Fernandes Ramos, que residia em São Paulo e cujas terras compreendiam, inclusive, as que hoje pertence ao município de Itu. Pouco antes de falecer, Manuel Fernandes partilhou suas terras entre seus sete filhos e a porção exata na qual Itu está situada ficou para o seu filho Domingos Fernandes, também bandeirante. Este, desenvolveu grande amor pela terra herdada de seu pai e, junto a seu genro Cristóvão Diniz, ergueu em 2 de fevereiro de 1610 uma capela em homenagem à Nossa Senhora da Candelária chamada de "Capella de N. Senhora da Candelaria de Ytu-guassú". Data desta época a fundação do município.

Domingos Fernandes mudou-se, com sua família, de São Paulo para suas terras junto da capela e, aos poucos, outras pessoas foram se instalando nos arredores. Nesta época, a economia do povoado baseava-se principalmente em atividades relacionadas às bandeiras, porém com o constante passar dos bandeirantes a localidade começou a crescer e a ter uma importância maior no cenário regional. Em 1653 o lugarejo foi elevado à condição de freguesia e, depois de quatro anos, em 18 de Abril de 1657 é elevado à condição de vila, sendo a sétima criada na capitania de São Paulo, que ainda fazia parte da Capitania do Rio de Janeiro. 
Durante o meio e final do século XVIII com a economia baseada na cana-deaçúcar, a vila era uma dos mais importantes centros agrícolas da província de São Paulo como relatou o capitão general Governador Bernardo José de Lorena em seu relatório, apresentado em 1793 ao governo da metrópole:

A agricultura achasse em hum progresso muito grande, desorte que se pode dizer que se acabou a preguiça deq. era geralmente acuzada a Capitania de São Paulo só a Vila de Itu faz mais de sincoenta mil arrobas de assucar por anno e vae em argumento. (NARDY FILHO, 1999, vol.5, p.14).

Em 2 de Dezembro de 1811 a vila de Itu foi elevada à condição de comarca, exercendo a sua jurisdição desde Franca até Curitiba. Era a comarca de Itu a mais movimentada e importante da capitania, sendo seu ouvidor o ituano Dr. Fernando Pacheco Jordão.

Em sessão de 25 de Fevereiro de 1842, a câmara de Itu toma conhecimento da portaria do presidente da província, que vinha acompanhada da lei de 5 do mesmo mês, e que elevava a vila à condição de cidade.

A cidade de Itu foi um dos três distritos da província de São Paulo de onde mais partiram colonizadores rumo ao Brasil central. Foi uma das primeiras cidades dotadas de infra-estrutura, tais como: calçamento, iluminação pública, água encanada e outros. As ruas da cidade de Itu começaram a ser calçadas em 1790, e ela passou a ter iluminação com lampiões em 1864, sendo que em 1904 foi inaugurada a iluminação elétrica. 
Em Dezembro de 1904, começou a cidade de Ytu a ser illuminada a luz elétrica (...) (NARDY FILHO, 1999, vol.1, p.208).

De 1910 até 1930, com a economia baseada na cafeicultura, Itu conheceu um grande crescimento econômico, porém após 1940 seguiu a tendência de muitos municípios do estado de São Paulo, substituiu a sua base econômica do setor primário (café) para o setor secundário (indústria). Itu urbanizou-se rapidamente, e foi a partir desse ponto que os problemas da falta de água se tornaram mais graves e intensos.

Restringindo-nos a dados da metade do século XX em diante, e baseados nos dados do IBGE, verificamos que entre os anos de 1970 a 2000 a população ituana apresentou um crescimento significativo de $276 \%$ em sua população total, passando de 49.091 habitantes em 1970 para 135.366 habitantes em 2000. O aumento da população urbana foi ainda maior passando de 36.041 habitantes em 1970 para 123.942 habitantes em 2000 , um crescimento de $344 \%$.

Destacamos ainda, que além do núcleo urbano principal, Itu conta com um núcleo urbano secundário, distante $15 \mathrm{~km}$ da cidade e denominado bairro Pirapitingui, cuja população é de mais de 35 mil habitantes. Este bairro foi um distrito no passado, e perdeu esta denominação em meados de 1993 quando o poder público municipal, temendo uma possível separação e fundação de um novo município neste local, extendeu o perímetro urbano de Itu até as bordas do bairro impossibilitando a fragmentação. Na ocasião, o bairro rural de nome Cruz das Almas, que faz limite à nordeste com a cidade e a sudeste com o antigo distrito do Pirapitingui, passou a fazer parte do perímetro urbano através de um decreto municipal (Figura 2). O principal argumento da prefeitura na época era que uma parte das indústrias do município 


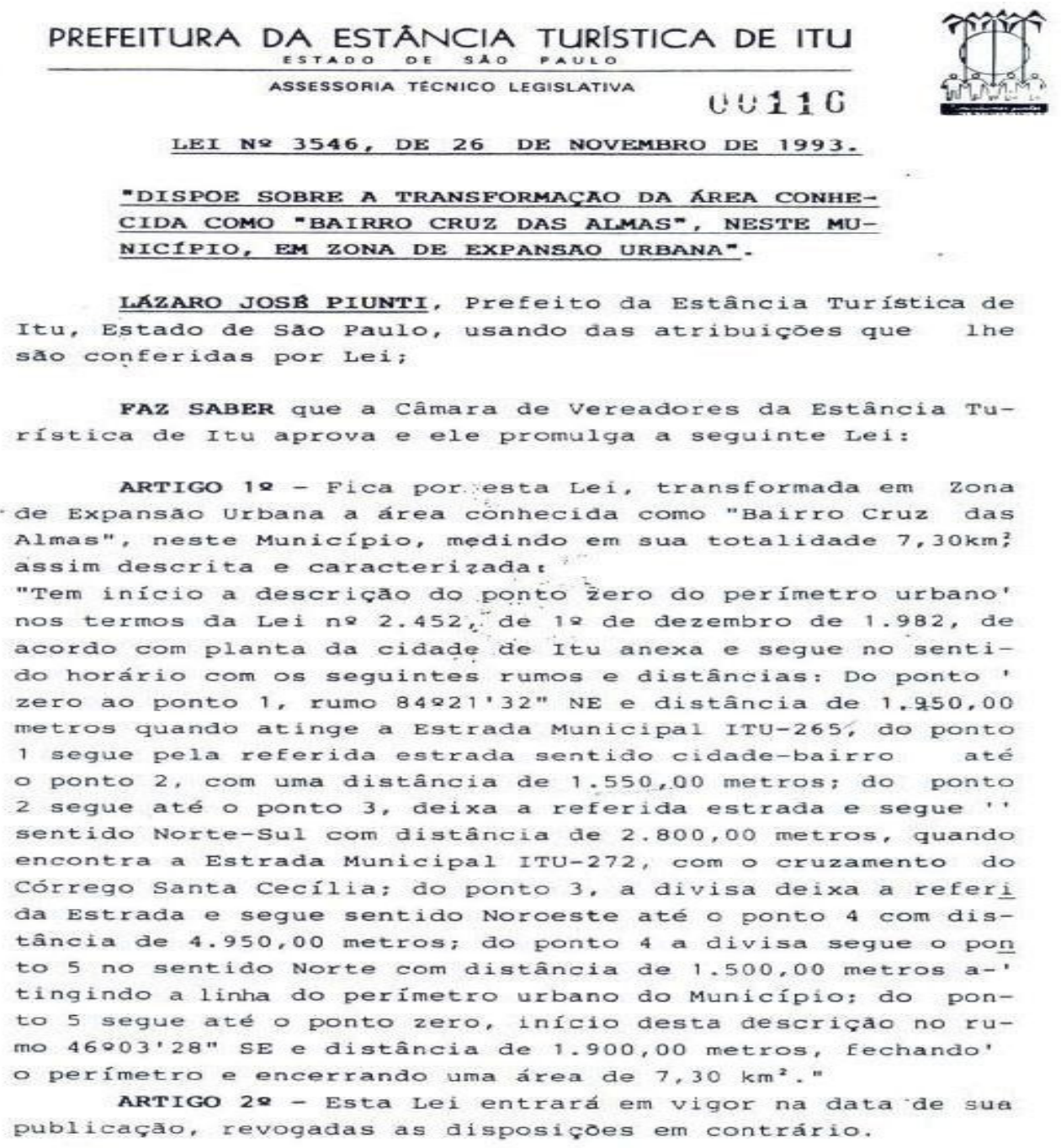

I.AZARO Josk PIUNTI. Prefeito da Estância Turística de Itu, Estado de sao Paulo, usando das atribuiçoes que lhe sao conferidas por Lei:

FAz SABER que a Camara de Vereadores da Estância Turistica de Itu aprova e ele promulga a seguinte Lei:

ARTIGO 10 - Fica por esta Lei, transformada em zona de Expansao urbana a área conhecida como "Bairro cruz das Almas", neste Municipio, medindo em sua totalidade $7,30 \mathrm{~km}$ ? assim descrita e caracterizada.

"Tem inicio a descricăo do ponto żero do perímetro urbano. nos termos da Lei ne 2.452, de 18 de dezembro de 1.982 , de acordo com planta da cidade de Itu anexa e segue no sentido horário com os seguintes rumos e distâncias: Do ponto ' zero ao ponto 1, rumo $84221.32 \%$ NE e distância de 1.950.00 metros quando atinge a Estrada Municipal IrU-265. do ponto 1 segue pela referida estrada sentido cidade-bairro até - ponto 2, com uma distancia de $1.550,00$ metros; do ponto 2 segue até o ponto 3 , deixa a referida estrada e segue.. sentido Norte-Sul com distancia de $2.800,00$ metros, quando encontra a Estrada Municipal ITU-272, com o cruzamento do Córrego Santa Cecilia; do ponto 3. a divisa deixa a referi da Estrada e segue sentido Noroeste até o ponto 4 com distância de 4.950 .00 metros; do ponto 4 a divisa segue o pon to 5 no sentido Norte com distância de 1.500,00 metros a-" tingindo a linha do perimetro urbano do Municipio: do ponto 5 segue até o ponto zero, inicio desta descriçao no rumo 46003'28" SE e distância de 1.900, 00 metros, fechando. - perímetro e encerrando uma área de $7,30 \mathrm{~km}^{2}$. =

ARTIGo 29 - Esta Lei entrará em vigor na data de sua publicaçao. revogadas as disposiçoes em contrário.

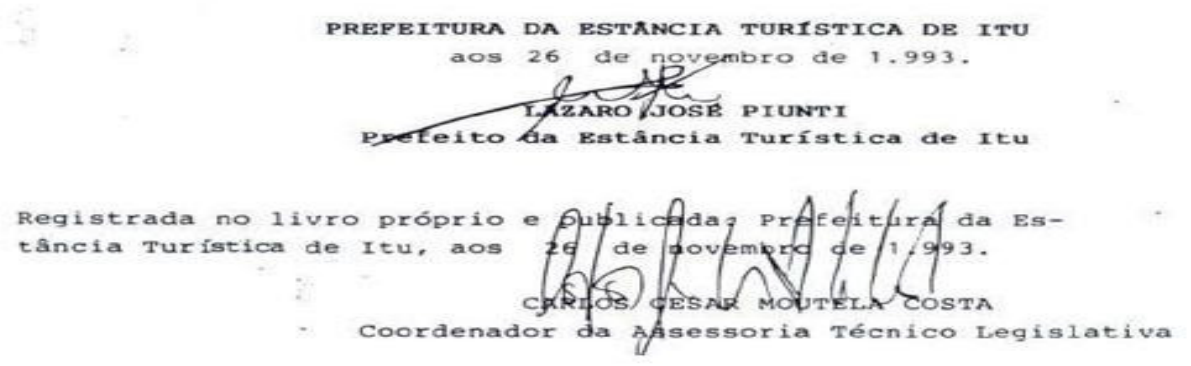

Figura 2 - Decreto municipal no 3546 de expansão do perímetro urbano de Itu-SP. Fonte: Prefeitura da Estância Turística de Itu, 1993. Adaptado por Rodrigues, 2007. 
estariam localizadas dentro da área pretendida pelo distrito, e, caso ocorresse a separação, Itu reduziria o seu PIB e a arrecadação municipal de impostos.

Um outro aspecto que merece destaque, é a existência de diversos condomínios que se distribuem por quase toda a área municipal, a instalação destes condomínios tem relação direta com a proximidade da capital paulista e as diversas vias de acesso que unem esta metrópole ao município. Em boa parte destes condomínios residem paulistanos que trabalham na capital durante o dia e pela noite retornam a Itu para pernoitarem, isso lhe confere também o título de "cidade dormitório".

Vale destacar que todos os aspectos citados acima estão estritamente relacionados com a questão do abastecimento público municipal de água, evidenciando que há algumas décadas este serviço está sob enorme pressão. Esta situação se deve, sobretudo ao expressivo aumento populacional e as mudanças de ciclos econômicos, que acabaram por aumentar demasiadamente a demanda por água. 


\section{6 - Caracterização físico-natural do município de Itu-SP}

O município de Itu situa-se entre o Planalto Cristalino e a Depressão Periférica Paulista, na zona do médio Tietê (Figura 3), região constituída principalmente por sedimentos com áreas expressivas de intrusões de rochas básicas com reflexos na sua topografia (IPT, 1981, p.58).
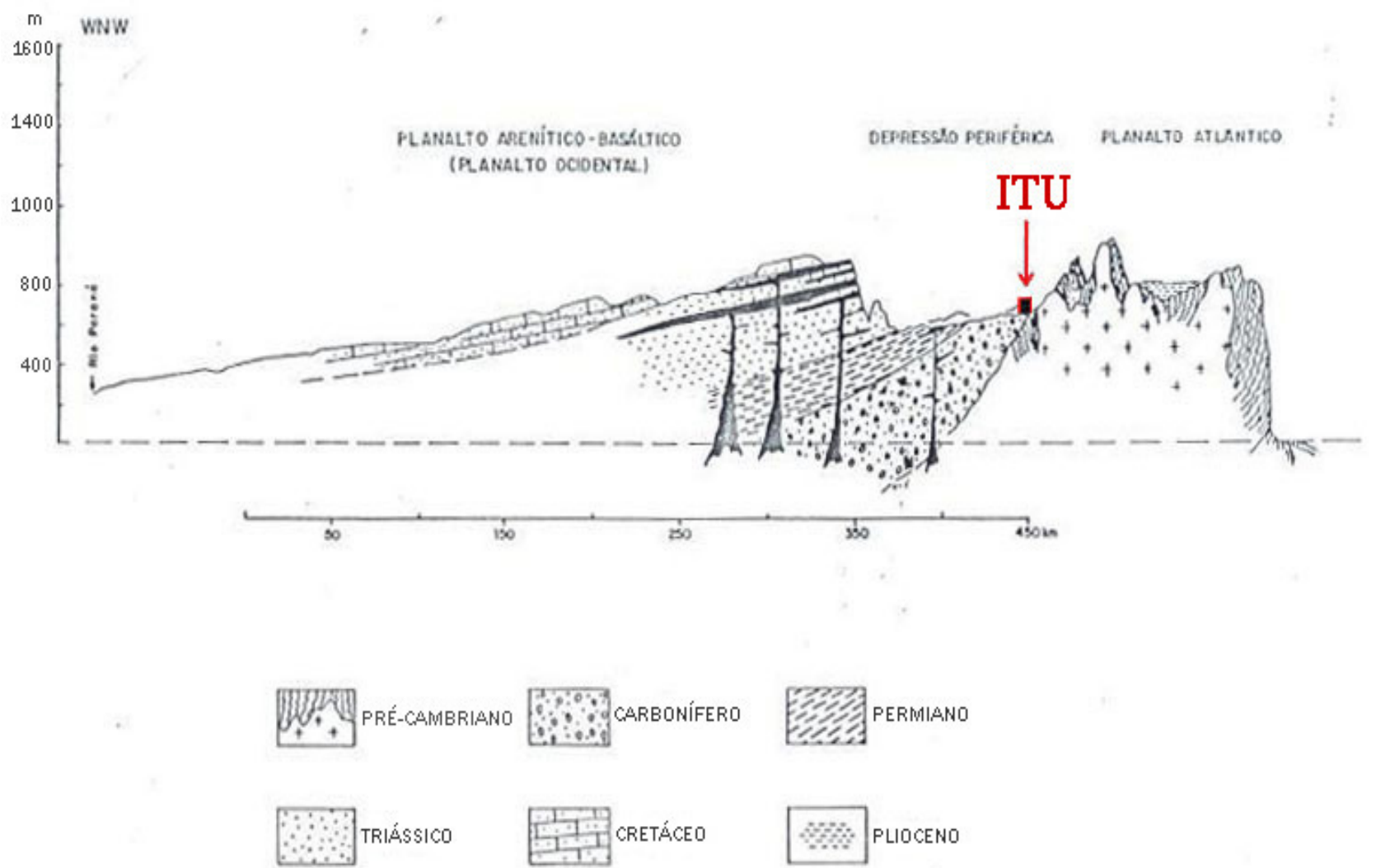

Figura 3 - Seção geológica-geomorfológica esquemática do estado de São Paulo destacando a localização do município de Itu.

Fonte: Modificado de Ab' Saber, 1956. 
Em Itu, "predominam colinas baixas, de formas suavizadas separadas por vales jovens, sem planícies aluviais importantes, determinadas pela intersecção dos perfis convexos das encostas". (ALMEIDA, 1964, p.229). Nesta região também é comum a presença do relevo de morros com serras restritas, típicos de áreas cristalinas e sustentados por rochas do embasamento e por alcalinas intrusivas, dentro da bacia sedimentar (IPT, 1981, p.58).

É possível dividir o município em duas regiões, na primeira predominam Colinas (porção Ocidental), e na outra predominam relevos mais acidentados de morros e morrotes (porção Oriental). Podemos evidenciar que a primeira região se distribui sobre rochas sedimentares e a segunda se distribui por sobre as rochas magmáticas e metamórficas, o que revela a intensa relação existente entre a geomorfologia e as unidades geológicas (Figura 4).

De modo geral o município em foco possui relevo de colinas suaves, com altitudes que variam, em média, de 500 a 700 metros, com desníveis locais pouco acentuados.

Próximo ao leito do rio Tietê a altitude não ultrapassa 480 metros, porém nos limites do município, tanto a leste como a nordeste, as altitudes chegam a alcançar os 1000 metros. Estas elevações são sustentadas por corpos intrusivo básicos (IPT, 1981, p.58). A maior parte do relevo do município é pouco suscetível a processos erosivos, contudo algumas porções da zona rural apresentam a ocorrência de sulcos erosivos e de ravinamentos.

Em termos geológicos o município de Itu apresenta uma sucessão de rochas variadas pertencentes a diferentes eventos geológicos. O embasamento é constituído por gnaisses e micaxistos do Complexo Brasileiro, formados no Pré-Cambriano Inferior. Sobre 


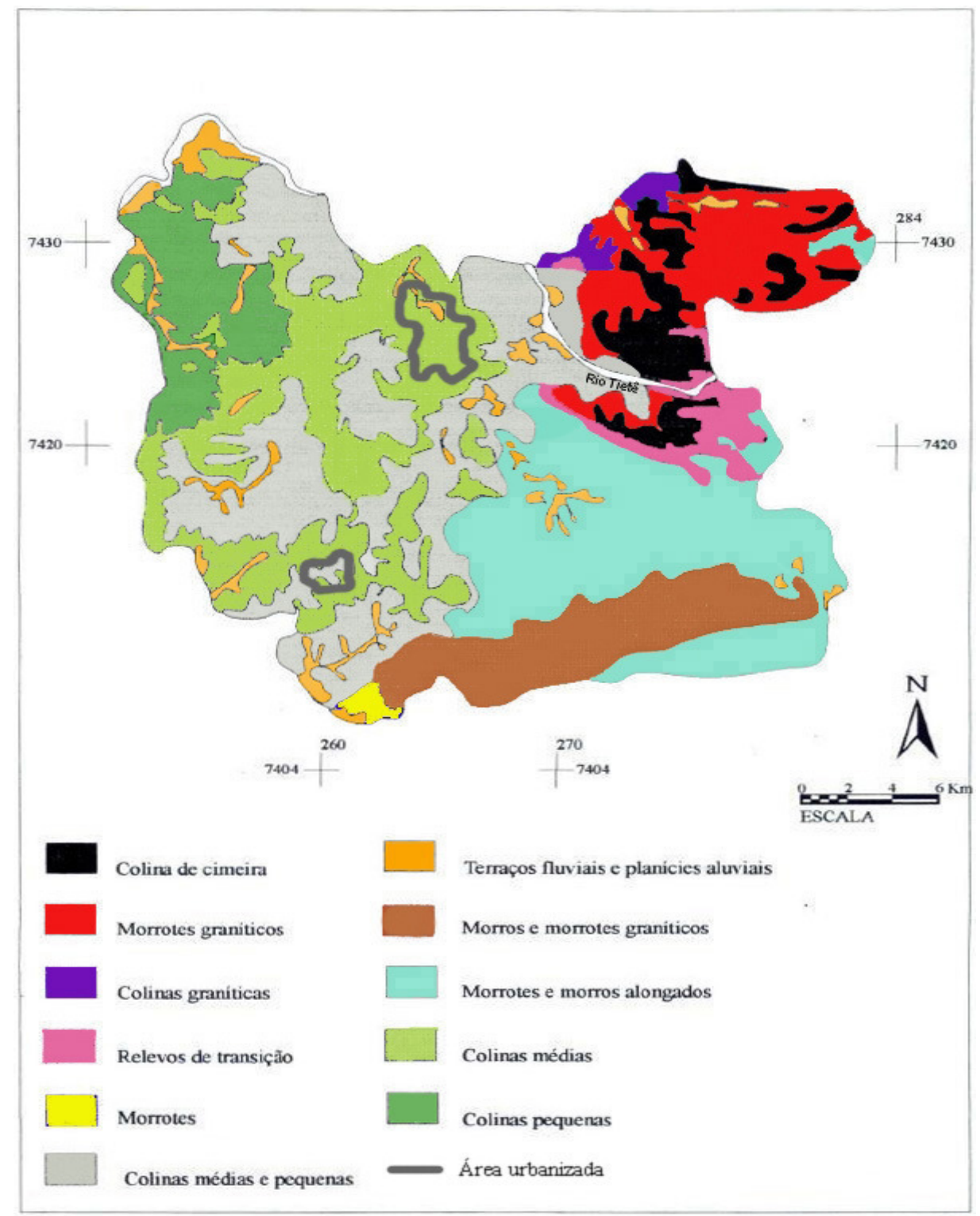

Figura 4 - Unidades geomorfológicas do município de Itu-SP. Fonte: IG-SMA, 1991. Adaptado por Rodrigues, 2007.

o embasamento ocorrem xistos, filitos e metaconglomerados do Grupo São Roque. No topo observa-se a ocorrência de rochas do Supergrupo Tubarão (arenitos, siltitos, filitos, varvitos e conglomerados), que apresentam a idade do Carbonífero Superior. 
Na metade oriental do município ocorrem rochas cristalinas (pré-cambrianas), que se subdividem em magmáticas (granitos Itu, Salto e Sorocaba) e metamórficas (Complexo Itapira e Grupo São Roque) (Figura 5).

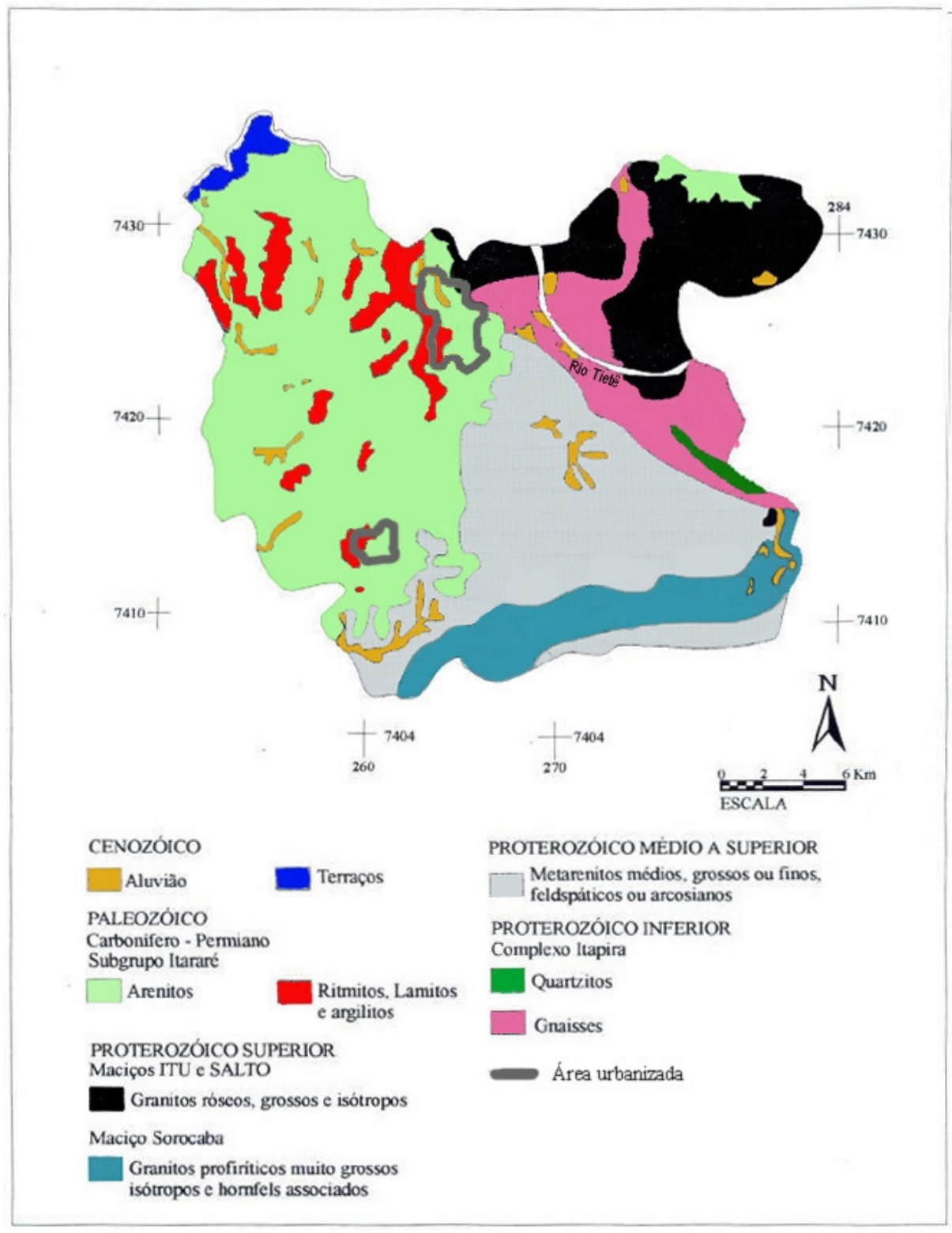

Figura 5 - Unidades geológicas do município de Itu-SP. Fonte: IG-SMA, 1991. Adaptado por Rodrigues, 2007. 
As rochas graníticas apresentam granulação mais grossa e são isótropas (não mostram foliações). As rochas metamórficas apresentam foliações marcantes. O grupo São Roque é afetado por inúmeras dobras de direções distintas que fazem com que a direção do seu bandamento seja muito variável (IG-SMA, 1991, p.7).

$\mathrm{Na}$ porção ocidental do município de Itu verifica-se a presença de rochas sedimentares pertencentes ao subgrupo Itararé, que na realidade consistem em arenitos de idade Permo-carbonífera (figura 5). São muito conhecidos também os Varvitos, que são depósitos formados pela alternância de sazonalidades (verão e inverno), durante o período glacial (Figura 6).

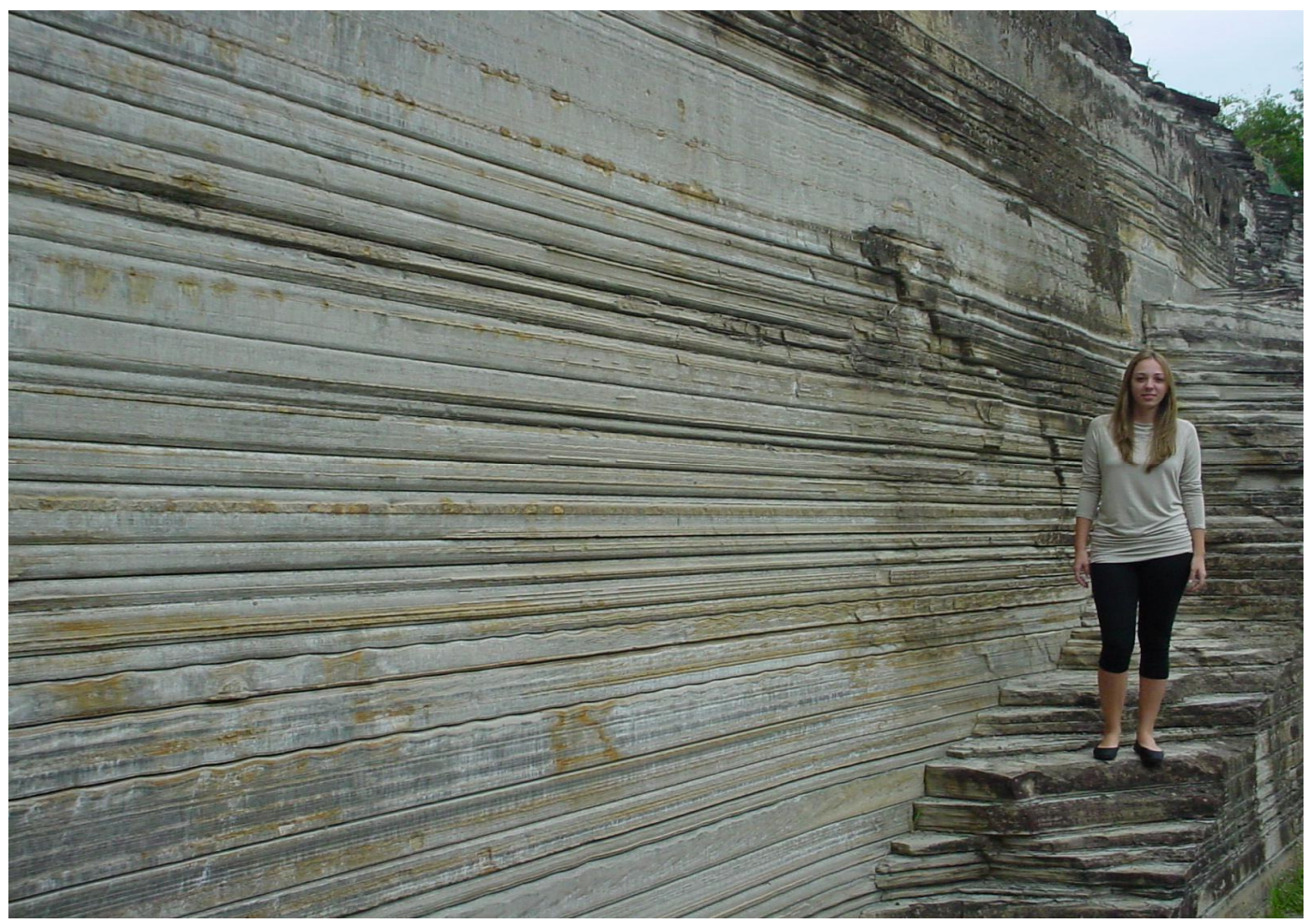

Figura 6 - Aspectos gerais do Varvito. As camadas horizontais indicam a alternância de sazonalidades ocorrida no Pleistoceno.

Fonte: Rodrigues, 2007. 
O varvito é um ritmito constituído por sucessão regular de pares de litologias incluindo camada/lâmina inferior, mais grossa, clara, de arenito fino-siltito, encimada por lâmina mais fina, escura, de siltito/argilito. A espessura das camadas/lâminas claras varia verticalmente, mas a das lâminas escuras mantêm-se constante (ROCHACAMPOS, 2000).

Por se tratar de um tipo raro de formação geológica, geólogos de todo o Brasil e até de outros países do mundo são atraídos até Itu, onde podem observar e estudar as peculiaridades deste tipo de rocha, tão bem evidenciáveis na porção oeste da cidade. A princípio o local era uma pedreira, porém encontra-se hoje devidamente protegido através de diversas medidas tomadas em âmbito estadual e municipal. As duas principais foram o tombamento parcial da pedreira, em 1974, pela Secretaria de Estado da Cultura de São Paulo, e a criação do "Parque do Varvito" em 1993 pela prefeitura.

Finalmente, cita-se também a ocorrência de intrusões graníticas ácidas posteriores ao Grupo São Roque, que afloram por entre os falhamentos pré-existentes na porção nordeste do município.

Itu destaca-se por apresentar um dos principais pólos ceramistas do estado de São Paulo, com grande extração de argila vermelha. A exploração mineral no município também é relevante com destaque para a extração de areia para a construção civil, granito e varvito (Figura 7).

Um importante ponto a ser analisado é a relação entre a geologia do município e a ocorrência de recursos hídricos subterrâneos. Os recursos hídricos subterrâneos constituem a origem dos escoamentos básicos dos rios e representam reservas de água geralmente de boa qualidade, porém nem todas as formações geológicas possuem características hidrodinâmicas satisfatórias para a exploração de poços profundos com 
grandes vazões de água. Os sistemas aqüíferos podem ser classificados basicamente em duas categorias segundo a natureza dos terrenos e suas propriedades hidráulicas: os aqüíferos cristalinos, permeáveis por fissuramento de rochas, e os aqüíferos sedimentares, permeáveis por porosidade granular.

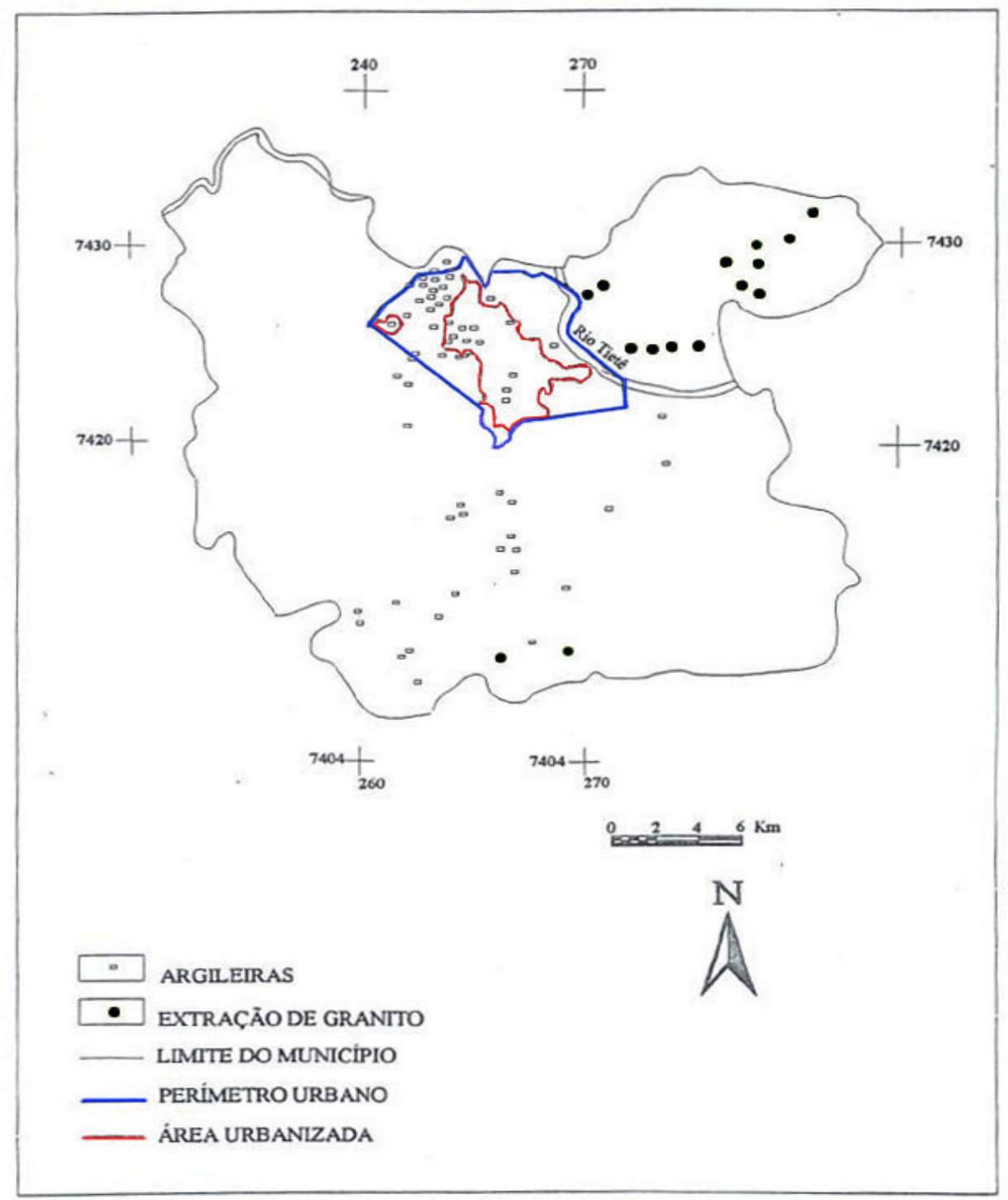

Figura 7 - Principais áreas de exploração de argila e granito no município de Itu-SP. Fonte: IG-SMA, 1991. Adaptado por Rodrigues, 2007. 
No caso de Itu, ocorrem dois sistemas de aqüíferos: o cristalino, formado por rochas do embasamento pré-cambriano, granitos e gnaisses no qual as captações de água estão associadas a fraturas das rochas, e o Tubarão (Subgrupo Itararé), com extensão regional descontínua, formado por rochas arenosas intercaladas em camadas de Siltitos, Ritmitos e Lamitos (DGA-UNESP, 1998, 53-54). No primeiro caso, a disponibilidade de água é relativa, e varia conforme a região. Em Itu, O município não está localizado sobre importantes falhas geológicas, o que Ihe confere uma pequena disponibilidade de água subsuperficial neste compartimento. Com relação ao Sistema Tubarão, ele normalmente não é considerado muito generoso em termos de disponibilidade de água, o que faz também que o município também não tenha reservas subterrâneas significativas em áreas localizadas sobre este sistema.

Como pudemos verificar, no geral Itu não possui uma boa oferta de água subsuperficial capaz de abastecer uma parcela considerável da população, a água existente é pouca pois os poços artesianos apresentam baixa vazão. Normalmente estes poços são suficientes somente para abastecimento de pequenas vilas e lugarejos, porém, se o investimento for maior pode-se conseguir um resultado um pouco melhor do que o habitual. Isso vem acontecendo atualmente com alguns empresários locais que estão investindo na captação de água subterrânea para posterior comercialização do recurso, principalmente nas épocas de estiagem.

No que diz respeito à pedologia, os tipos de solo encontrados no município de Itu segundo o Sistema Brasileiro de Classificação de Solos - Embrapa (1999) são: Argissolo Vermelho-Amarelo 71\%, Latossolo Vermelho 21\% e o Neossolo Litólico, que compreende os $8 \%$ restantes. O Argissolo e o Latossolo possuem espessuras que variam de 0,5 a 3,0 $\mathrm{m}$, com baixa intensidade de processos erosivos, presença de ravinamentos restritos 
associados aos desmatamentos e a drenagem de estradas. Já o Neossolo Litólico apresenta espessura de 0,5 a 1,0 metro e média intensidade de processos erosivos.

A vegetação original predominante é a de Mata Atlântica com algumas manchas de Cerrado, porém a ação humana já devastou grande parte destas formações vegetais, sobretudo para dar lugar a construções urbanas e a prática agropecuária.

O município possui clima variando do tropical de planalto com variações locais ao subtropical com a temperatura média entre $16^{\circ}$ e $22^{\circ}$, sendo que o verão é quente e úmido, e o Inverno é moderadamente frio e seco. A precipitação anual é da ordem de $1.300 \mathrm{~mm}$, sendo que nos meses de inverno as precipitações mensais ficam abaixo de 50 $\mathrm{mm}$ e no verão as precipitações mensais chegam a $200 \mathrm{~mm}$. A umidade relativa do ar varia de 60 a $80 \%$, com temperatura média no período diurno entre 22 a $28^{\circ} \mathrm{C}$ e máximas de $32^{\circ} \mathrm{C}$.

A sazonalidade exerce grande influência no problema da falta de água, porque são nos meses mais secos o problema ocorre com maior intensidade. Ela exerce influência também na demanda por água, pois no verão o consumo sobe cerca de 5 a $10 \%$ e no inverno o consumo cai cerca de $6 \%$ em relação à média anual do município.

Com relação à hidrografia, Itu insere-se quase que totalmente na sub-bacia do Médio Tietê Superior, com uma área equivalente a $2.550 \mathrm{~km}^{2}$. Uma pequena parte do seu território, a sudoeste, pertence à sub-bacia do rio Sorocaba/Piraju, com uma área total de $1.309 \mathrm{~km}^{2}$ (DGA-UNESP, 1998, p.5). O município possui 14 microbacias hidrográficas sendo que 12 pertencem a bacia hidrográfica do Rio Tietê (5 são utilizadas para abastecimento público), e 2 pertencem a bacia hidrográfica do rio Sorocaba (1 é utilizada para abastecimento público) (quadro 1). 
Quadro 1 - Panorama geral das 14 microbacias do município de Itu-SP

\begin{tabular}{|c|c|c|c|c|}
\hline MICROBACIA & LOCALIZACÁO & SITUACÃO & $\begin{array}{c}\text { AREA } \\
\text { (APROX) }\end{array}$ & BACIA \\
\hline $\begin{array}{l}\text { 1. Rio Piraí e afluentes } \\
\text { (Ribeirão do Ingá e } \\
\text { Ribeirão Cana Verde) }\end{array}$ & $\begin{array}{l}\text { Manancial utilizado pelos } \\
\text { municipios de Salto e } \\
\text { Indaiatuba. }\end{array}$ & $\begin{array}{l}\text { Rio intermunicipal tendo } \\
\text { suas cabeceiras na Serra do } \\
\text { Japi, Municipio de Jundiai. } \\
\text { Potencial a ser reavaliado } \\
\text { no PDA. }\end{array}$ & A ser calculada & $\begin{array}{l}\text { Jundiai/ } \\
\text { Tietê } \\
\text { (margem } \\
\text { direita) }\end{array}$ \\
\hline 2. Rib. Itaquá & $\begin{array}{l}\text { Divisa com Cabreúva } \\
\text { (Serra do Itaquá). }\end{array}$ & $\begin{array}{l}\text { A ser avaliada no PDA. 2/3 } \\
\text { da área no Municipio de } \\
\text { Cabreúva. }\end{array}$ & $11 \mathrm{~km}^{2}$ & $\begin{array}{l}\text { Tietê } \\
\text { (margem } \\
\text { direita) } \\
\end{array}$ \\
\hline 3.Córrego São José & & \begin{tabular}{|l|} 
Manancial de Itu \\
\end{tabular} & $9 \mathrm{~km}^{2}$ & $\begin{array}{l}\text { Tieté } \\
\text { (margem } \\
\text { direita) }\end{array}$ \\
\hline 4. Córrego Gomes & $\begin{array}{l}\text { Condominio Sto Antonio } \\
\text { a leste da cidade }\end{array}$ & Manancial de Inu & $17 \mathrm{~km}^{2}$ & $\begin{array}{l}\text { Tietê } \\
\text { (margem } \\
\text { esquerda) } \\
\end{array}$ \\
\hline 5. Córrego Braiaiá & A sudeste da cidade & Manancial de Itu & $46,6 \mathrm{~km}^{2}$ & $\begin{array}{l}\text { Tietê } \\
\text { (margem } \\
\text { esquerda) } \\
\end{array}$ \\
\hline $\begin{array}{l}\text { 6. Ribeirão } \\
\text { Pirapitingui }\end{array}$ & $\begin{array}{l}\begin{array}{l}\text { A sul da cidade com } \\
\text { captaça na represa do } \\
\text { Fubaleiro. }\end{array} \\
\end{array}$ & $\begin{array}{l}\text { Manancial de Itu } \\
\text { * abastece } 70 \% \text { da cidade }\end{array}$ & $72,5 \mathrm{~km}^{2}$ & $\begin{array}{l}\text { Tietê } \\
\text { (margem } \\
\text { esquerda) }\end{array}$ \\
\hline 7. Ribeirâo Itaim Guaçú & A oeste/sudoeste da cidade & Manancial de Itu & $62 \mathrm{~km}^{2}$ & $\begin{array}{l}\text { Tietê } \\
\text { (margen } \\
\text { esquerda) }\end{array}$ \\
\hline 8. Ribeirão Itaim Mirim & A sudoeste da cidade & \begin{tabular}{|l|} 
Situa-se a jusante da área \\
urbana de Itu, recebendo \\
lançamento de esgoto em \\
dois pontos
\end{tabular} & $18 \mathrm{Km}^{2}$ & $\begin{array}{l}\text { Tietê } \\
\text { (margem } \\
\text { esquerda) }\end{array}$ \\
\hline 9. Rio Itaim & A oeste da cidade & A ser avaliada no PDA & $22 \mathrm{Km}^{2}$ & $\begin{array}{l}\text { Tietê } \\
\text { (margem } \\
\text { esquerda) } \\
\end{array}$ \\
\hline $\begin{array}{l}\text { 10. Ribeirão } \\
\text { Coiacatinga/ } \\
\text { Purunduva }\end{array}$ & $\begin{array}{l}\text { Junto à divisa com Porto } \\
\text { Feliz }\end{array}$ & $\begin{array}{l}\text { A ser avaliada no PDA } \\
\text { Microbacia intermunicipal }\end{array}$ & \begin{tabular}{|l|}
32 a $35 \mathrm{Km}^{2} \mathrm{em}$ \\
Itu
\end{tabular} & $\begin{array}{l}\text { Tietê } \\
\text { (margem } \\
\text { esquerda) }\end{array}$ \\
\hline $\begin{array}{l}\text { 11. Rio Putribú de } \\
\text { Cima/Mombaça }\end{array}$ & $\begin{array}{|lr|}\text { No extremo } & \text { sudeste do } \\
\text { Municipio, junto a divisa } \\
\text { com São Roque e e } \\
\text { Mairinque }\end{array}$ & $\begin{array}{l}\text { A ser avaliada no PDA. } \\
\text { Maior parte da microbacia } \\
\text { fora do Municipio. }\end{array}$ & $\begin{array}{l}35 \text { a } 37 \mathrm{~km}^{2} \mathrm{em} \\
\text { Itu }\end{array}$ & $\begin{array}{l}\text { Tietê } \\
\text { (margem } \\
\text { esquerda) }\end{array}$ \\
\hline $\begin{array}{l}\text { 12. Corrego do Pau } \\
\text { D'alho }\end{array}$ & $\begin{array}{|lll|}\text { Junto à divisa } & \text { com } \\
\text { Cabreúva } & & \\
\end{array}$ & A ser avaliada no PDA & $21 \mathrm{~km}^{2}$ & $\begin{array}{l}\text { Tietê } \\
\text { (margem } \\
\text { esquerda) } \\
\end{array}$ \\
\hline $\begin{array}{l}\text { 13. Ribeirão do } \\
\text { Varejão }\end{array}$ & $\begin{array}{l}\text { No extremo sul do } \\
\text { Municipio. junto à divisa } \\
\text { com Sorocaba e Mairinque }\end{array}$ & $\begin{array}{l}\text { Manancial de Itu (Cidade } \\
\text { Nova/Pirapitingui) }\end{array}$ & $26 \mathrm{Km}^{2}$ & $\begin{array}{l}\text { Pirajibul } \\
\text { Sorocaba }\end{array}$ \\
\hline $\begin{array}{l}\text { 14. Ribeirão da Tapera } \\
\text { Grande }\end{array}$ & $\begin{array}{l}\text { No extremo sudoeste do } \\
\text { Município, junto à divisa } \\
\text { com Sorocaba }\end{array}$ & $\begin{array}{l}\text { A ser avaliada no PDA } \\
\text { recebendo lançamento de } \\
\text { esgoto }\end{array}$ & $\begin{array}{l}25 \mathrm{~km}^{2} \\
\mathrm{em} \mathrm{Itu}\end{array}$ & $\begin{array}{l}\text { Pirajibu/ } \\
\text { Sorocaba }\end{array}$ \\
\hline
\end{tabular}

FPDA = Plano Diretor de Águas

Fonte: DGA-UNESP, 1998. 
A drenagem é de forma dendrítica, bastante organizada, com destaque para o Rio Tietê, que corta o município de Itu a Norte, sendo ele, indiscutivelmente, o seu mais importante rio. Sua largura média, no trecho em que passa pelo município, é de 50 metros, com profundidade média de 3 metros, sendo que durante a época de estiagem o seu nível cai cerca de 0,5 metros. Já na época de grande precipitação o seu nível sobe cerca de 1 metro.

Itu conta também com outros cursos de água que passam pelo município. Entre os mais expressivos podemos citar: Ribeirão Pirapitingui, Ribeirão do Taquaral, Ribeirão Itaim Guaçú, Ribeirão Varejão, Córrego Braiaiá, Córrego dos Gomes e Córrego São José (Figura 8)1. Todos estes têm suas águas utilizadas para o abastecimento público, uma vez que as águas do Tietê estão totalmente poluídas.

O Ribeirão Pirapitingui é o principal manancial de abastecimento público de Itu, localiza-se na periferia da cidade onde existe a represa do "fubaleiro", resultante do barramento deste manancial para a captação de água. Deste Ponto são captados $330 \mathrm{l} / \mathrm{s}$ e enviados para tratamento e posterior distribuição na estação de tratamento de água (ETA I) localizada no bairro rancho grande, a 1,6 km do local de captação. A microbacia do Pirapitingui abrange uma área de $73 \mathrm{~km}^{2}$ e tem como principais cursos de água, além do próprio Ribeirão Pirapitingui, o Ribeirão Taquaral (do qual recebe água proveniente de uma represa de acumulação com o mesmo nome), o Córrego Santa Cecília e o Ribeirão Monjolinho. O principal problema que afeta os cursos de água desta microbacia é o assoreamento, ocasionado, sobretudo, pelas inadequadas movimentações de terra para a construção de condomínios e pelo manejo agrícola inadequado.

1 O mapa contendo todos os cursos de água existentes no município de Itu-SP encontra-se no CD em anexo. 
O Ribeirão Itaim Guaçú é o segundo em importância em razão do maior volume de água captada, suas águas abastecem cerca de $30 \%$ da população do núcleo urbano

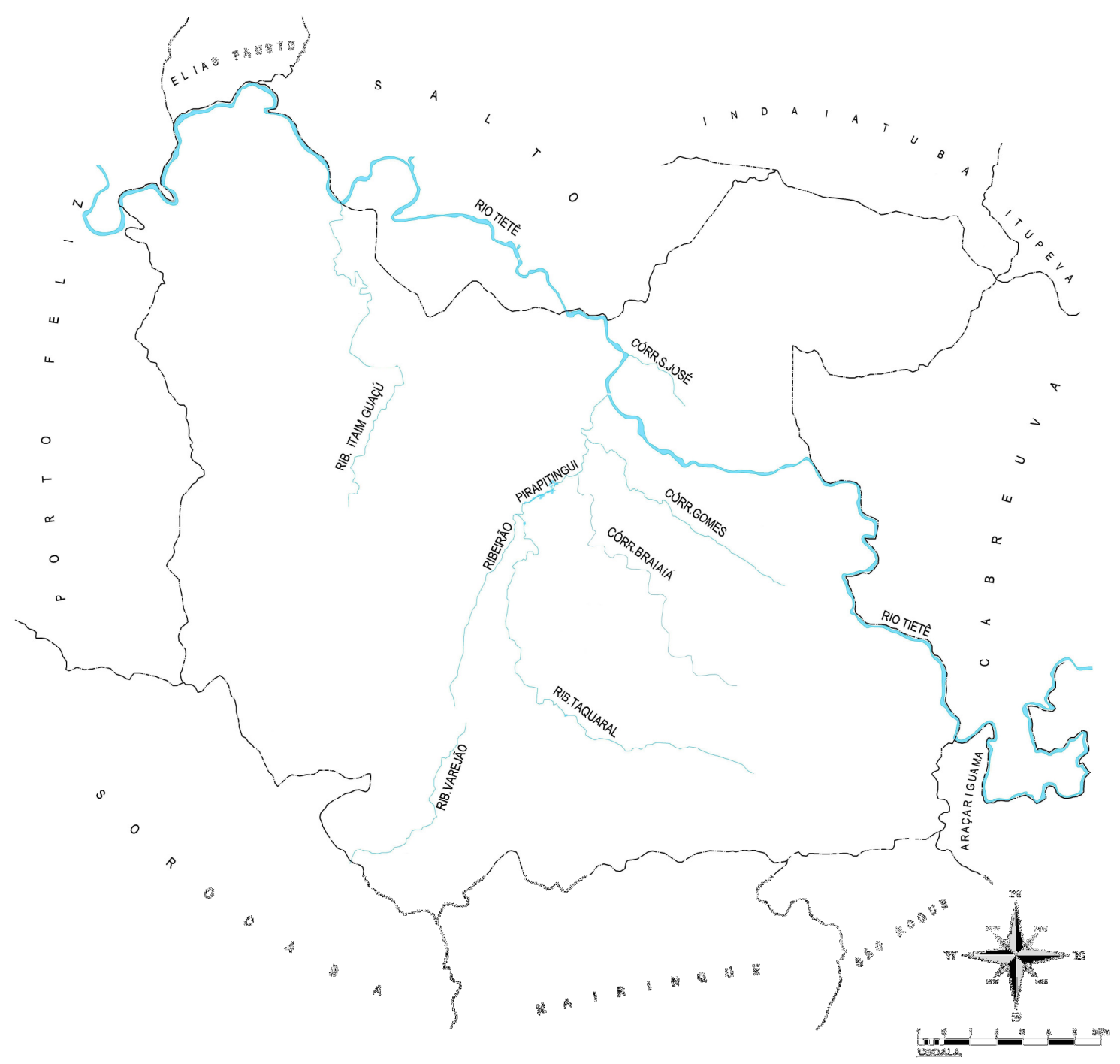

Figura 8 - Principais cursos de água do município de Itu-SP.

Fonte: Prefeitura da Estância Turística de Itu, 2002. Adaptado por Rodrigues, 2008. 
principal de Itu. A captação é feita numa represa denominada barragem Itaim, localizada próxima à rodovia Marechal Rondon (SP-300) e a água é enviada para tratamento na ETA VII situada no mesmo local da captação. A microbacia do Itaim Guaçú tem $62 \mathrm{~km}^{2}$ e seus principais cursos de água são, além do Rio Itaim Guaçú os Córregos da Taperinha, do Deserto, da Conceição, Jacu e Bernardino. Em relação aos principais problemas que afetam esta microbacia podemos destacar a poluição causada pelo uso indiscriminado de pesticidas agrícolas e principalmente os assoreamentos resultantes da extração de argila.

Outro manancial com relativa importância no município de ltu é o córrego do Braiaiá com $47 \mathrm{~km}^{2}$. A captação é realizada por meio da represa também chamada Braiaiá, localizada a Sudeste da cidade. Este manancial tem sua captação interligada ao sistema de tratamento, reservação e distribuição ETA I, fornecendo para este sistema 100 l/s. (DGA-UNESP, 1998, p.37). A microbacia do Braiaiá tem como curso de água secundário o Córrego do Brás que se localiza dentro de uma propriedade particular denominada Fazenda Santa Marta. Os principais problemas existentes na microbacia estão associados à proximidade dos mananciais com os "lixões", ao assoreamento e ao mal uso dos recursos hídricos por particulares, principalmente a captação intensa e desordenada da água para uso nas atividades agrícolas (irrigação).

O Ribeirão do varejão recebe as águas do córrego da Campininha e do Córrego do Barreiro, e é responsável por abastecer o núcleo urbano secundário do Pirapitingui. Já o Córrego dos Gomes e o Córrego São José são os que possuem a menor vazão dentre os principais cursos de água do município, ambos não possuem afluentes importantes e abastecem o núcleo urbano principal.

Vale ressaltar que a poluição dos mananciais do núcleo urbano principal por lançamento de esgoto sem tratamento é praticamente nula ( $98 \%$ de esgoto tratado). Já 
no núcleo urbano secundário do Pirapitingui o tratamento é inexistente e o esgoto é lançado in natura no Córrego Tapera Grande e Ribeirão Varejão (a jusante do ponto de captação para abastecimento público). Esses corpos de água correm para fora do município e são afluentes do Ribeirão Pirajibú, que é o principal afluente do Rio Sorocaba, rio este pertencente à bacia do Rio Sorocaba também na região do Médio Tietê Superior.

Após receber esta carga de esgoto proveniente do município de Itu, o rio recebe ainda uma carga ainda mais pesada proveniente do município de Sorocaba. Toda esta poluição misturada a água vai à direção Noroeste do estado onde é captada pelo município de Cerquilho-SP. Este município, distante $60 \mathrm{~km}$ de Itu, acaba por sofrer sérias conseqüências econômicas e sociais advindas desta situação. Entre as principais podemos citar principalmente a proliferação de doenças relacionadas à contaminação da água e o alto custo do tratamento da água para torná-la potável novamente. 


\section{7 - Caracterização socioeconômica do município de Itu-SP}

A população estimada do município de Itu segundo o IBGE para o ano de 2007 é de 147.157 habitantes, das quais $93 \%$ se concentram na zona urbana e $7 \%$ na zona rural. A densidade demográfica para o ano de 2006 é de 235,62 Hab/km² e a taxa de crescimento populacional é de 2,29\% ao ano. A taxa de natalidade em Itu é de 15,48 nascidos por 1000 habitantes, a taxa de fecundidade é de 53,73 filhos por 1000 mulheres (15-49 anos) e a de mortalidade infantil é de 11,53 mortos por 1000 nascidos.

A expectativa de vida no Município de Itu é de 73 anos, e a taxa de escolaridade é considerada baixa com uma média de 7,2 anos de estudo por habitante (entre 15 e 64 anos). O índice de analfabetismo é de 7,47\%.

Dentro da classificação pelo Índice Paulista de Responsabilidade Social - IPRS, que avalia a dimensão da riqueza, a dimensão da longevidade e também a dimensão da escolaridade, o município se encontra no grupo 2 (municípios que, embora com níveis de riqueza elevados, não exibem bons indicadores sociais). Apesar disso, o Índice de Desenvolvimento Humano Municipal - IDH é considerado alto $(0,815)$.

Em relação à habitação e a infra-estrutura urbana Itu apresenta $81,72 \%$ da população vivendo em domicílios com espaço suficiente e 94,93\% de domicílios com infra-estrutura interna adequada. A coleta de lixo atende $98,49 \%$ da população, o nível de atendimento de água tratada é de $97,33 \%$ e o de esgoto sanitário é de $95,45 \%$ dos domicílios.

Também segundo o IBGE (2006) o PIB municipal é de $\mathrm{R} \$ 2.122,74$ (em milhões de reais correntes) e a renda per capita da população ituana é $R \$ 14.174,50$. A participação no PIB do estado é de $0,388 \%$ e nas exportações do estado é de $0,241 \%$. As 
atividades mais desenvolvidas na cidade estão relacionadas à produção industrial, ao comércio varejista e às atividades agropecuárias e de extração mineral. Vale ressaltar que apesar de ostentar o título de "Estância Turística de Itu" e do seu potencial para desenvolver a atividade nos setores histórico, religioso e, principalmente pela fama de "cidade dos exageros", o turismo não é um dos pontos fortes da economia Ituana.

O município passou a ostentar este rótulo à partir da década de 60 , quando o humorista ituano Francisco Flaviano de Almeida criou o personagem "Simplício" e passou a divulgar o município em programas humorísticos como "A terra onde tudo é grande". A fama se espalhou por todo o estado de São Paulo e pelo Brasil devido à atuação do comediante por décadas na mídia brasileira, sobretudo em programas de grande repercussão nacional como "A praça é nossa" do Sistema Brasileiro de Televisão - SBT. Apesar do número de turistas aumentar nas últimas décadas, o município ainda lucra muito pouco com este tipo de atividade, parece faltar uma política municipal que aborde e aproveite melhor o potencial turístico que o município possui em diferentes modalidades.

No setor industrial, temos como maior destaque a indústria alimentícia, onde podemos citar a Schincariol e a Elma Chips, as duas maiores indústrias de Itu e, juntas, responsáveis por boa parte do PIB municipal e da oferta de emprego local. Estas duas empresas certamente são as que mais sofrem com a falta de água, pois, além de serem grandes utilizam a água como matéria prima essencial. A Schincariol conta hoje com uma estação de captação e tratamento de água particular, o que a torna mais independente nesta questão, e diminui seus prejuízos na época de escassez do recurso. Já a Elma Chips normalmente se abastece da rede pública municipal, exceto nos períodos de estiagem quando passa a comprar água de particulares até que a situação se normalize. Outros ramos que se destacam são o da metalurgia, indústria eletrônica e de 
eletrodomésticos. A Indústria ceramista também merece destaque uma vez que o município é um dos principais pólos ceramistas do Estado de São Paulo.

O comércio varejista também é importante para a economia Ituana e se destaca principalmente no setor alimentício e de vestuário. O setor agropecuário tem razoável participação nas atividades econômicas municipais com destaque para a produção de hortifrutigranjeiros, suínos, pecuária extensiva e ovina.

Em relação às atividades agrícolas existentes no município de Itu, alguns aspectos devem ser mencionados, pois estão estritamente relacionados aos recursos hídricos. $\mathrm{O}$ primeiro refere-se à quantidade de água utilizada para a irrigação. Esta água é captada durante $\mathrm{o}$ ano todo a montante dos mananciais que abastecem a cidade, o que nas épocas de estiagem acaba por afetar o volume que chega até a barragem de captação, tornando-o mínimo. O segundo são os assoreamentos, que geralmente estão relacionados à práticas incorretas de manejo do solo tais como retirada da cobertura vegetal, falta de curvas de nível, inexistência de terraceamento etc.

O município de Itu caracteriza-se também pela produção de bens minerais não metálicos, mais especificamente aqueles utilizados na construção civil. Em ordem decrescente de importância temos a produção de argila comum para a produção de cerâmica, rochas dimensionadas (granito ornamental e pedras de talhe de cantaria), material de empréstimo (saibro e cascalho) e finalmente areia. (DGA-UNESP, 1998, p. 11)

Contudo, muitas são as empresas responsáveis pela extração destes recursos, que acabam por degradar o meio natural, pois não se utilizam de técnicas apropriadas, contribuindo assim para aumentar o quadro de degradação ambiental no município. Segundo dados do Instituto Geológico/ Secretaria do Meio Ambiente (IG-SMA, 1991, 
anexo 4.3), a área degradada pela exploração inadequada de argila no município chegava na época a 162 hectares.

Certamente um dos principais problemas decorrentes deste tipo de atividade, assim como na agricultura, são os assoreamentos dos cursos de água próximos aos locais degradados, uma vez que os processos erosivos se intensificam e as partículas do solo desprendidas são carreadas pela água pluvial até os fundos dos vales, onde se encontram cursos de água. Os mananciais que abastecem o município recebem uma grande carga de sedimentos advindos deste tipo de atividade o que diminui consideravelmente a capacidade de armazenamento de água, agravando o problema.

As estradas vicinais contribuem também para o processo de assoreamento, uma vez que no verão são atingidas por fortes chuvas e sofrem processos erosivos. Os sedimentos advindos destes locais contribuem também para o entupimento dos cursos de água municipais. 


\section{8 - O problema da escassez de água}

Analisando dados históricos encontrados em documentos oficiais do município e do estado, pudemos verificar a ocorrência de alguns problemas após a formação do núcleo urbano de Itu, tanto os relacionados à falta de moradias apropriadas, como à falta de arruamentos e, principalmente, problemas relacionados a falta de água, como mostra o historiador Ituano Francisco Nardy Filho em seu livro "A Cidade de Ytu".

Nardy Filho reserva todo um capítulo para tratar do abastecimento de água na cidade, este capítulo se encontra no primeiro dos cinco volumes de sua obra escrita em 1928 e reeditada em 1999. Numa passagem, pudemos constatar a existência de problemas ligados ao abastecimento de água há pelo menos dois séculos, conforme citação a seguir:

(...) Desse modo, embora toda a previdência de seu fundador, já em começo de 1800 estava a villa Ytuana com falta de água. (NARDY FILHO, 1999, vol.1, p. 210).

Os problemas da falta de água se intensificaram durante o século XIX e o poder público pouco fez para repará-los. Particulares e pessoas ligadas a outros setores, como a igreja por exemplo, constantemente intervinham na questão a fim de minimizar os infortúnios enfrentados pela população. Segundo relatos históricos, a primeira obra para trazer água de mananciais vizinhos até a vila de Itu foi feita na primeira década de 1800 a mando de um padre ituano que utilizou recursos próprios, como podemos verificar nesta passagem: 


\section{(...) Por esse tempo o Padre Antônio Pacheco da Silva, que em suas} visitas ás famílias de suas relações e parentesco, ouvia sempre a queixa geral contra a falta de água, condoeu-se da população (...) e dispondo de avultados bens de fortuna, resolveu dotar a sua custa, a villa ytuana de água encanada... captou elle as águas de uma vertente próxima, e, servindo de grandes telhões de barro fez um encanamento com o qual conseguiu trazer água á cidade . (NARDY FILHO, 1999, vol.1, p.210).

Apesar destas obras na região central, alguns anos depois foram construídos dois chafarizes novamente com recursos de particulares. O primeiro foi construído por um seminarista chamado Joaquim Francisco do Livramento e o segundo pelo cirurgião Antônio José de Babo Broxado. Porém, mesmo assim, os problemas persistiram como comprova a citação abaixo:

Em 1820 e 1821 foram construídos os chafarizes, ou melhor, as bicas chamadas do Padre Campos e do Broxado (...) Servida desse modo a população, e dado o seu crescimento, que vinha se verificando de anno para anno, começou logo a mesma a sentir novamente a falta de água. (NARDY FILHO, 1999, vol.1, p.211).

No início do século XX o problema ainda persistia e piorava de forma preocupante ano a ano sendo por inúmeras vezes o principal assunto debatido no município. Numa outra passagem do livro de Nardy Filho fica evidenciada a necessidade de melhorar o 
setor de abastecimento de água na época, já que este estava novamente no seu limite e não suportaria o crescimento populacional e industrial do município:

Possuía a cidade de Ytu o seu abastecimento de água; porém, com o aumento sensível da população, com o desenvolvimento de suas indústrias, no correr de alguns annos as águas captadas no manancial da Fazenda da Serra não bastavam para suprir a população (...) Assim é que, em sessão de 15 de Abril de 1902, incumbiu o engenheiro Dr. Francisco de Mesquita Barros de proceder o estudo e exame de diversos mananciaes, a ver qual o melhor a ser captado. (NARDY FILHO, 1999, vol.1, p.223).

Fica claro como a questão dos recursos hídricos e, principalmente, os problemas relacionados à falta de água, estiveram historicamente ligados ao município.

Durante todo o século $\mathrm{XX}$ pudemos verificar que a ocorrência de problemas relacionados à falta de água tornou-se demasiadamente constante principalmente do meio para o final daquele século, devido, sobretudo, ao crescimento acelerado da população total e urbana. A população total quase que triplicou em 30 anos (1970-2000) (Tabela 1) e, consequentemente, cresceu a demanda por água neste período.

Contudo, foi a partir de 1990 que o problema do abastecimento público de água na cidade de Itu tornou-se crítico, atingindo seu ápice nos anos de 1999, 2000 e 2001 quando praticamente todo o estado de São Paulo passou por uma forte estiagem. Neste período os totais pluviométricos de Itu foram inferiores a média que é de $1300 \mathrm{~mm}$ o que agravou significativamente o problema. 
Tabela 1 - Evolução da população urbana, rural e total do município de Itu entre $1970-2006$

\begin{tabular}{|l|l|l|l|}
\hline Ano & Pop. Urbana & Pop. Rural & Total \\
\hline 1970 & $36.041(73 \%)$ & $13.050(27 \%)$ & $49.091(100 \%)$ \\
\hline 1980 & $63.174(85 \%)$ & $11.030(15 \%)$ & $74.204(100 \%)$ \\
\hline 1991 & $96.816(90 \%)$ & $10.498(10 \%)$ & $107.314(100 \%)$ \\
\hline 1996 & $112.006(91 \%)$ & $10.522(9 \%)$ & $122.528(100 \%)$ \\
\hline 2000 & $123.942(92 \%)$ & $11.424(8 \%)$ & $135.366(100 \%)$ \\
\hline $2007^{*}$ & $136.856(93 \%)$ & $10.301(7 \%)$ & $147.157(100 \%)$ \\
\hline
\end{tabular}

* estimativa

Fonte: www.ibge.gov.br, acesso em Abril de 2008. Organizado por Rodrigues, 2008.

No ano 2000, por exemplo, os totais pluviométricos não ultrapassaram os $466 \mathrm{~mm}$ e os principais reservatórios da cidade ficaram reduzidos a níveis muito baixos (5 a 10\% da oferta de água), levando a administração municipal a decretar estado de calamidade pública. Este ano inclusive é apontado como o mais crítico que o município enfrentou no que diz respeito à escassez de água para abastecimento público (Anexo 1).

$\mathrm{Na}$ ocasião, praticamente toda a cidade passou a viver em função de racionamentos crônicos. Em diversas ocasiões várias escolas, residências e indústrias tiveram que interromper seu funcionamento rotineiro por não terem disponibilidade de água potável, sendo que somente os hospitais, em função do caráter essencial que executam, tinham água sempre disponível. Por inúmeras vezes a prefeitura teve que recorrer à ajuda privada para tentar minimizar o problema em questão, utilizando-se de água subsuperficial captada em propriedades particulares, tarefa na qual obteve pouco 
sucesso já que a cidade não possui grandes lençóis subterrâneos e, consequentemente, os poços artesianos não apresentam boa vazão. Com a situação à beira de um colapso, a prefeitura aprovou uma lei que punia com multa de $R \$ 141,71$ (real de 2000) quem fosse flagrado desperdiçando água, como podemos comprovar num documento emitido pelo próprio SAAE na época dos acontecimentos (figura 9).

Os racionamentos na cidade de Itu costumam ser muito severos, chegando a abranger em algumas ocasiões mais de seis meses, não bastasse que durante a vigência dos mesmos o abastecimento residencial só ocorre no período noturno e da madrugada (das 22h às 6h).

A parcela da população que mais sofre com os racionamentos de água é a mais pobre, pois não possuem caixas de água para armazená-la quando os registros são abertos durante a noite e a madrugada, servindo-se apenas de reservatórios improvisados. A água, bastante suscetível a contaminações pelo manuseio incorreto, é posteriormente utilizada para uso doméstico inclusive no preparo de alimentos.

Esta prática tem causado uma maior incidência de doenças principalmente àquelas relacionadas diretamente à contaminação da água, como por exemplo, infecções estomacais, intestinais (diarréia e amebíase) e hepatite. Consequentemente há um maior gasto por parte da prefeitura com saúde pública, uma vez que a grande maioria dos doentes ocupa leitos de hospitais públicos.

Tendo em vista a situação problemática pela qual o município passa comumente, por inúmeras vezes ocorreram conflitos de opiniões que se arrastaram por décadas. A população acusava o poder municipal de não investir no setor, enquanto os órgãos municipais responsáveis, tais como a prefeitura e o Serviço Autônomo de Água e Esgoto 
(SAAE), apontavam a falta de chuva como a principal causa de falta de água no município.

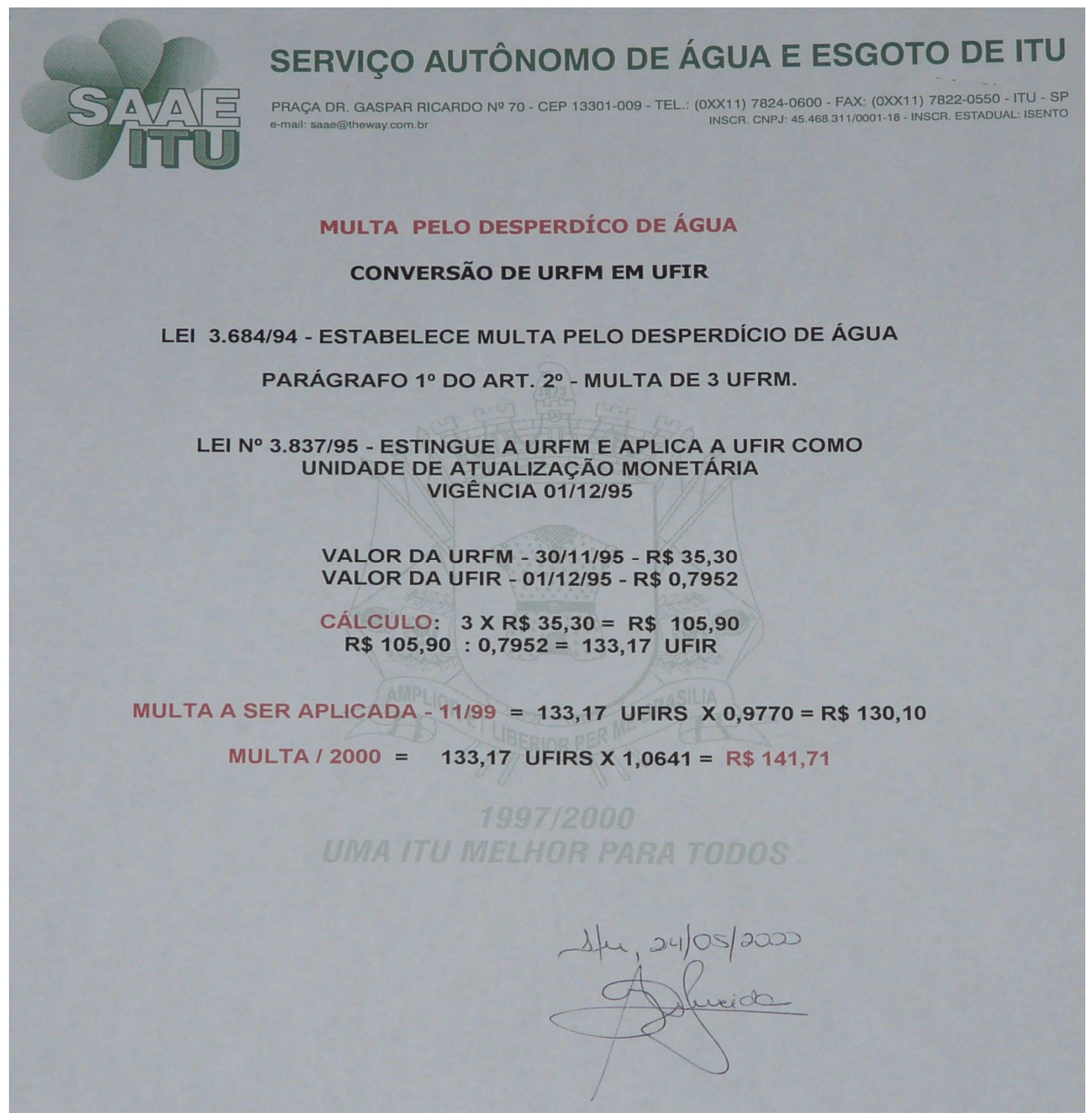

Figura 9 - Documento do SAAE confirmando a aplicação da multa de $\mathrm{R} \$ 141,71$ para quem fosse flagrado desperdiçando água em 2000.

Fonte: SAAE, 2000. Adaptado por Rodrigues, 2008. 
Como não se tinha certeza da causa do problema, pouca coisa era feita além de discussões e dos conflitos entre poder público e população. Esses desentendimentos aconteciam, sobretudo, nos meses de inverno quando normalmente ocorrem estiagens e o problema se agrava atingindo diretamente a vida de grande parte da população.

Somente as chuvas tinham o poder de minimizar os problemas da falta de água no município. Uma prova disso é que em anos nos quais o padrão médio da pluviosidade foi superior ao normal os problemas foram pequenos, ficando restritos a um curto período do ano, quase sempre os meses de Junho e Julho quando os totais pluviométricos são normalmente baixos ou nulos e a estiagem atinge seu auge.

Em 2003 foi publicado um estudo de autoria do mesmo autor desta dissertação para a obtenção do título de Bacharel em Geografia. Após uma análise geográfica com ênfase nos aspectos climatológicos, descobriu-se que a falta de chuva não era a principal causa da falta de água no município de Itu. Foram analisadas as médias pluviométricas anuais de Itu e mais treze cidades da região (Sorocaba, Capivari, Tietê, Porto Feliz, Elias Fausto, Araçoiaba da Serra, Iperó, Campinas, Cabreúva, Vinhedo, Jundiaí, Cajamar e São Roque) no período de 1967 - 1997. Este procedimento teve como intuito tentar encontrar uma relação entre a problemática e uma possível escassez de chuvas no município, tida como a principal causa da falta de água para abastecimento público pelo governo municipal.

Esta hipótese sempre foi a mais aceita no município, durante décadas a prefeitura acusou a falta de chuvas como agente causador do problema, conseguindo assim se esquivar de críticas e cobranças por parte da população que no final se conformava com a situação. A esta restava apenas ficar na expectativa da chegada do 
período de chuvas, quando poderia se ver livre dos problemas que enfrentava, pelo menos até os meses secos do ano seguinte quando eles provavelmente voltariam.

Com os dados do Banco de Dados Pluviométricos do Estado de São Paulo atualizados até 1997 pelo Departamento de Águas e Energia Elétrica do Estado de São Paulo (DAEE), da Secretaria de Recursos Hídricos, Saneamento e Obras, e com os recursos do software Surfer® Versão 6.0, da Golden Software Inc., foram construídas trinta figuras representando a pluviosidade regional de cada ano do período 1968-1997. Os anos Foram classificados em secos, tendentes a secos, padrão médio, chuvosos e tendentes a chuvosos. Buscou-se uma classificação pluvial que não fosse limitada aos rígidos padrões espaciais das isoietas médias, agora, focando Itu e arredores, na tentativa de alcançar as configurações que mais se repetiam, isto é, aquelas mais freqüentes no período 1968-1997.

Desta maneira, observando as trinta cartas de isoietas construídas, foi estabelecida a seguinte classificação espacial (RODRIGUES, 2003, p.34):

- Anos que se configuraram secos: 1968, 1969 e 1985.

- Anos com "tendência" a secos: 1971, 1978, 1980, 1981, 1984 e 1994.

- Anos com configuração assemelhada ao padrão espacial médio: 1973, 1974 , 1975, 1977, 1979, 1988, 1990 e 1992.

- Anos com "tendência" a chuvosos: 1970, 1972, 1986, 1987, 1989, 1993 e 1997.

- Anos que se configuraram chuvosos: 1976, 1982, 1983, 1991, 1995 e 1996.

$\mathrm{Na}$ ocasião, a "tentativa" de classificação apontou, em trinta anos, freqüência muito mais elevada de anos com "tendência" a chuvosos (sete) e de anos chuvosos 
(seis), do que de anos secos (três) ou com "tendência" a secos (seis). Assim, contra o total de nove anos: 1968, 1969, 1971, 1978, 1980, 1981, 1984, 1985 e 1994, secos ou "tendentes a" (que poderiam causar - ou causaram - problemas no abastecimento de água em Itu), registraram-se outros treze: 1970, 1972, 1976,1982, 1983, 1986, 1987, 1989, 1991, 1993, 1995, 1996 e 1997, chuvosos ou com "tendência a".

Além desse fato marcante, notou-se que os anos "verdadeiramente" secos, teoricamente mais problemáticos para Itu, ocorreram no final dos anos sessenta (1968 e 1969) e, depois, uma única vez na década de oitenta (1985). De todo

modo, em qualquer um desses três anos secos, a população de Itu era bem menor que a de hoje.

Já os anos chuvosos: 1976, 1982, 1983, 1991, 1995 e 1996, distribuíram-se pelas três últimas décadas. Tais anos, se juntamente considerados com os de "tendência" a chuvosos: 1970, 1972, 1986, 1987, 1989, 1993 e 1997, revelam um encadeamento: 1970, 1972, 1976, 1982, 1983, 1986, 1987, 1989, 1991, 1993, 1995, 1996, 1997, que certamente deve ter favorecido a reposição hídrica dos mananciais do município em foco, usados na captação da água para o abastecimento urbano. Analisando a seqüência final, composta por todos os anos do período 1968-1997, observou-se que em três ocasiões (1968-1969; 1980-1981 e 1984-1985) o abastecimento de água em Itu poderia acusar - ou acusou - alguma dificuldade na captação em seus mananciais. Entretanto, vale lembrar, nesses anos a população era bem inferior a de agora. Deste então, houve apenas um ano seco dentro do período em estudo, ou seja, 1994. Finalizando este raciocínio, cabe lembrar que os outros dois anos secos (1971 e 1978), além de terem ocorrido ao longo dos anos setenta, foram ladeados 
por anos de boa pluviosidade: 1971, pelos anos úmidos de 1970 e 1972; e 1978, pelos anos "médios" de 1977 e 1979.

Sendo assim, pode-se concluir que o problema da escassez de chuva na região de Itu não se confirmou, rechaçando a hipótese alegada pelo poder público municipal, pois os anos que mais se repetiram dentro do período 1968/97 foram os de configuração espacial do tipo "médio", os com "tendência" a chuvosos, e os chuvosos, o que prova que a referida região não é seca, apesar de algumas de suas cidades estarem sob "sombra de chuvas".

MONTEIRO (1973) classifica esta região como "percê do Tietê", ou seja, o lado leste (virado para o Atlântico) tem altitudes superiores ao lado oeste e, consequentemente, maior pluviosidade devido ao efeito orográfico. Na Figura 10 podemos visualizar melhor estas informações.

Itu localiza-se exatamente na parte oeste onde as altitudes e as médias pluviométricas são levemente inferiores à de cidades localizadas à leste (Figura 11). Este fator contribui para um cômputo pluviométrico inferior ao habitual regional (por volta de 100 mm mensais) nas cidades situadas na região da "percê".

Contudo, ficou comprovado que esta questão não se relacionava diretamente com a falta de água, e que não era a principal causa da escassez do recurso para abastecimento público no município, já que o fenômeno atingia também municípios vizinhos à itu e que na grande maioria destes não eram comuns problemas graves com relação à falta de água.

Ao compararmos as médias pluviométricas anuais de Itu nas últimas décadas com a de outros municípios situados em outras regiões, como os municípios da região Oeste 
do estado, podemos verificar que nestes os índices pluviométricos são semelhantes ou inferiores aos de Itu e, apesar disso, também não enfrentam problemas desta natureza.

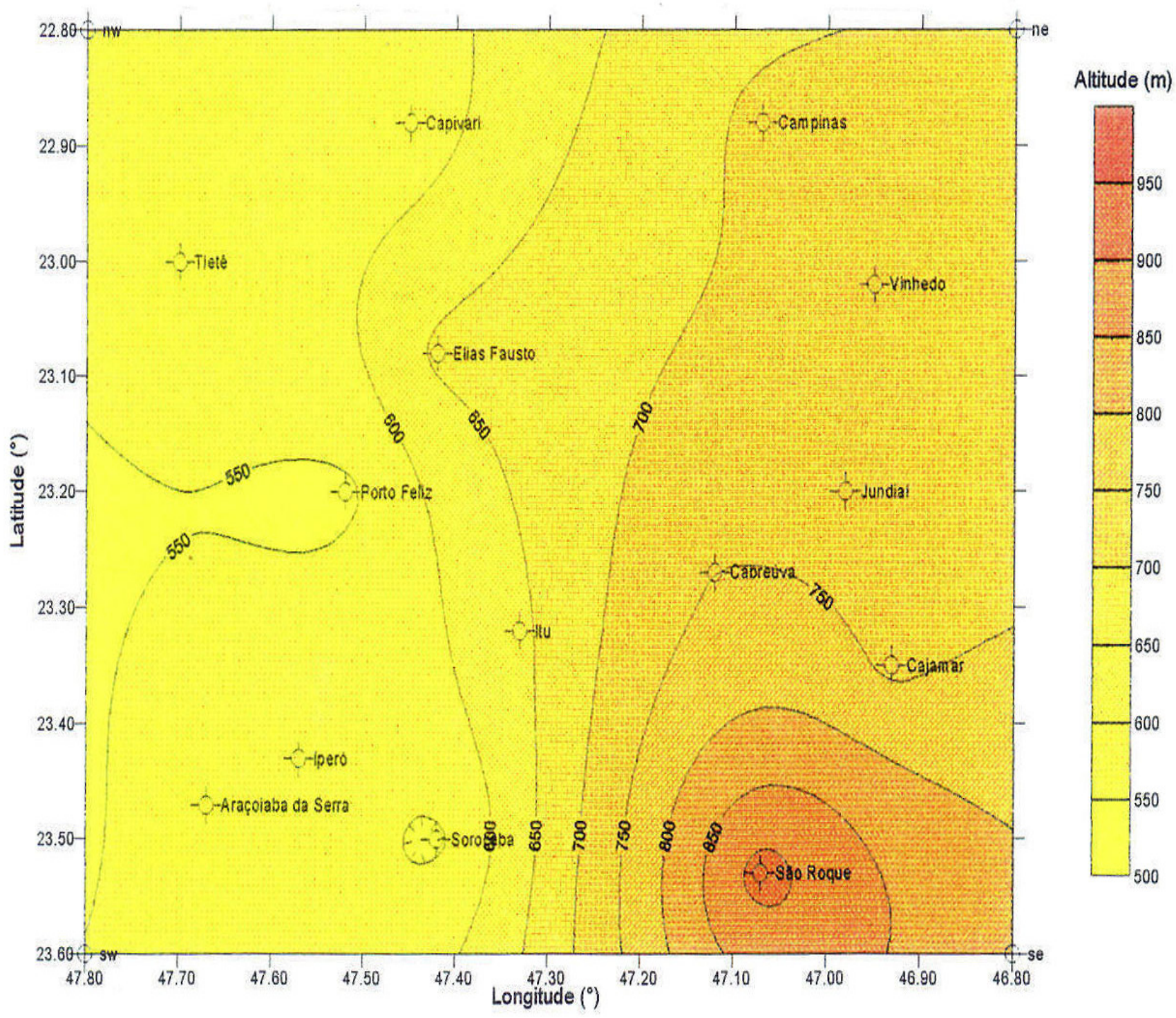

Figura 10 - A topografia na região de Itu-SP. Fonte: Rodrigues, 2003. 


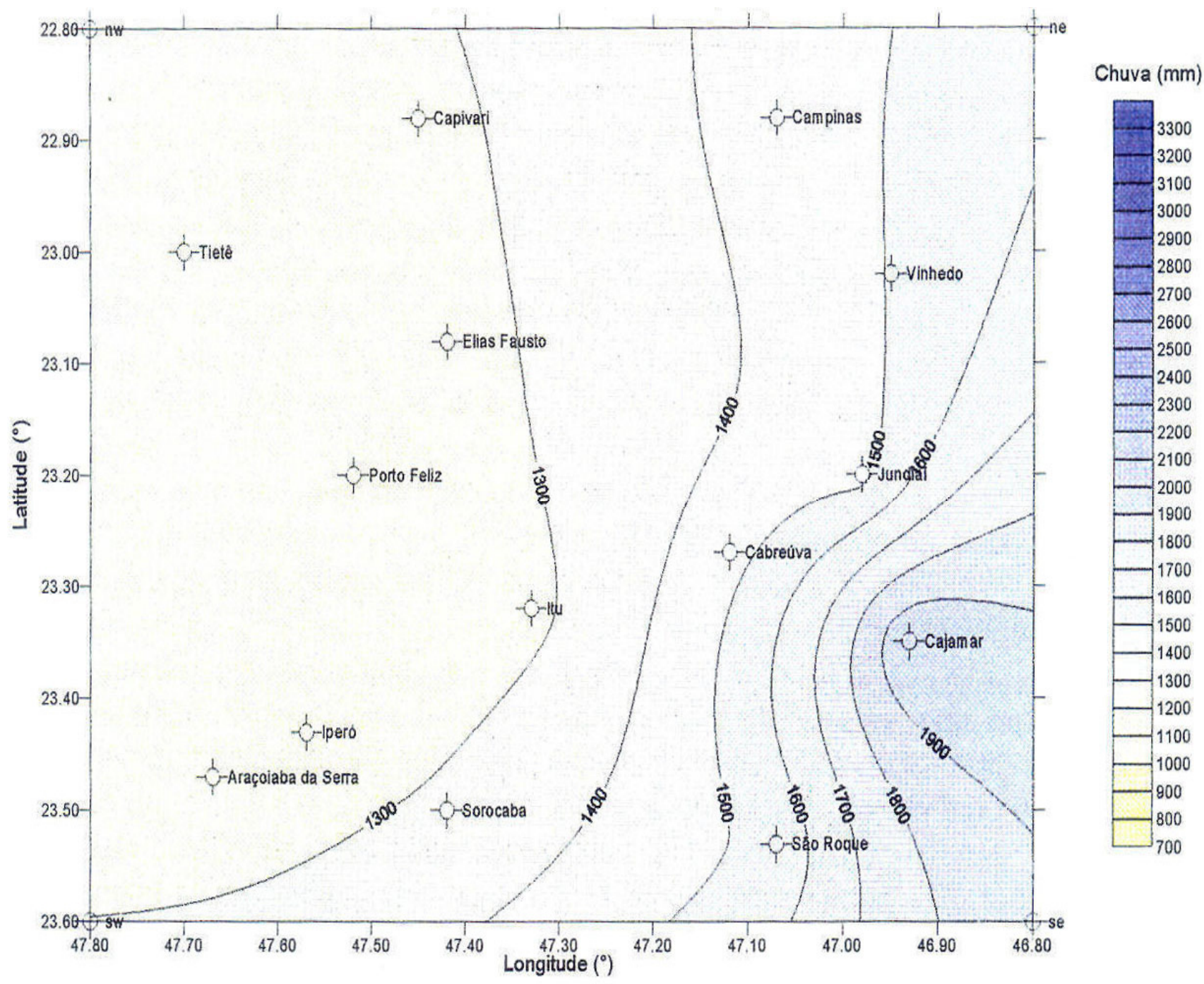

Figura 11 - A pluviosidade média na região de Itu no período de 1967 -1997. Fonte: Rodrigues, 2003.

O município de Araçatuba, localizado na parte Noroeste do estado e distante 530 km de São Paulo é um claro exemplo. Possui demanda maior com 181,598 habitantes (2006) e médias pluviométricas um pouco inferiores, e não apresenta tais problemas crônicos relacionados à falta de água. Presidente Prudente é outro exemplo de município 
com maior demanda $(204,036$ habitantes em 2006) e menor média pluviométrica, não apresenta também problemas relevantes neste setor. Evidente que para que esta comparação fosse válida foram levadas em consideração a similaridade de outras características geográficas relevantes como a geologia, o clima, a rede fluvial etc.

Os resultados apontados pela pesquisa mostraram que o problema da falta de água para abastecimento público no município não estava diretamente relacionado às questões pluviométricas como alegavam os órgãos da administração pública. Estes chegaram a apoiar-se durante décadas nesta idéia inclusive para livrar-se de críticas comumente recebidas da população e da mídia local, além de isentar-se de quaisquer responsabilidades jurídicas.

O problema da falta d'água no município de Itu não está diretamente relacionado com a pluviosidade, pois, apesar de estar localizado numa zona de "sombra de chuvas" pelo seu lado Leste, apresenta o mesmo volume pluviométrico de outras cidades da região, muitas das quais possuidoras de população bem superior à de Itu. Além do mais, o volume de chuvas em Itu é maior que o de muitos municípios do estado de São Paulo, cujas demandas são maiores em função do número de habitantes que possuem (...) Araçatuba, no Noroeste do estado, dentre tantas outras localidades do interior paulista. (RODRIGUES, 2003, p.44).

O poder público municipal afirmava também que além da pluviosidade, a hidrografia teria uma significativa parcela de culpa no problema, pois segundo eles, a 
oferta de água superficial era pequena. Essa idéia também foi rechaçada após o término da pesquisa em 2003 como podemos comprovar no trecho a seguir:

A hidrografia no município de Itu também exerce pouca influência sobre o problema, já que a oferta de água é relativamente boa. No entanto, é preciso que esta água seja captada de maneira consciente e sensata, ao contrário do que vem sendo feito, pois está captando-se muito mais do que a capacidade dos mananciais pode suportar. (RODRIGUES, 2003, p.45).

Ao término da pesquisa ficou provado que o problema era mesmo de ordem humana, relacionado à perda de água e não à falta desta como podemos verificar na citação a seguir:

O que realmente causa o problema da escassez de água para abastecimento público em Itu são os fatores técnicos (....) Redes e filtros de água obsoletos, falta de manutenção de redes de distribuição e de hidrômetros (...) causam enormes perdas que, em última análise, são as responsáveis imediatas pelos problemas relacionados ao abastecimento público de água em Itu. ( RODRIGUES, 2003, p.45).

Após a pesquisa foi confirmado que as perdas eram realmente elevadas, os cálculos na época, apontaram para uma perda física (na rede de distribuição) na ordem de $40 \%$. 
Segundo o relatório elaborado pelo Fórum Permanente das Relações Universidade-Empresa (UNIEMP) em 2006 para o SAAE as perdas físicas atuais são um pouco maiores do que em 2003 chegando à ordem de 43\%, sendo o valor final das perdas $55 \%$ do total da água captada como podemos verificar abaixo:

Pelos dados de volumes do sistema verifica-se que há uma perda total média da ordem de $55 \%$ do volume produzido, das quais $1 / 4$ são perdas de micro-medição e 3/4 são perdas físicas do sistema, decorrentes de água de processo e vazamentos na rede, que atingem o patamar de 1.750 L/h.km, muito alto, mesmo para uma situação de baixa manutenção. (UNIEMP, 2006, p.23).

Na figura abaixo (Figura 12) podemos visualizar melhor estes dados.

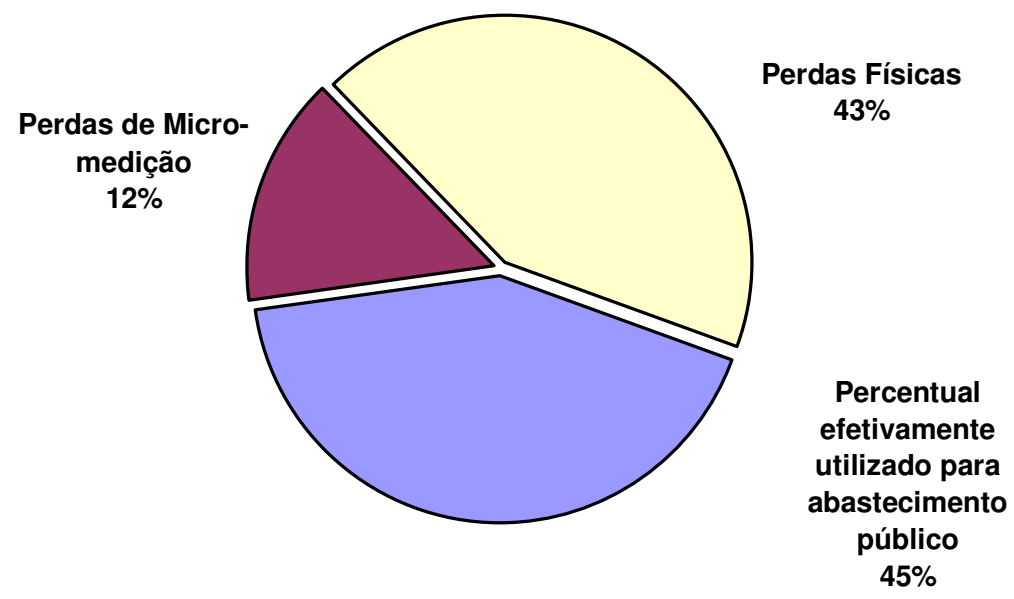

Figura 12 - Destino do volume total de água produzido no município de Itu-SP. Fonte: UNIEMP, 2006. Adaptado por Rodrigues, 2007. 
Como mostrado anteriormente, no caso de Itu, os problemas de perda de água estão relacionados entre outras coisas à utilização equipamentos velhos já danificados pela ação do tempo, e também à falhas na manutenção e operação do sistema.

ALLUCl et al (1998) diz que os programas de conservação de água devem dar incentivos financeiros sob a forma de juros subsidiados, ou redução de impostos a quem utiliza equipamentos eficientes. Também se deve taxar de modo punitivo quem utiliza equipamentos que consomem ou desperdiçam muita água. Segundo ALVES et al (1998) uma das formas de diminuir as perdas seria a implantação gradual da automação no serviço de água, pois isto reduziria a possibilidade de manobras inadequadas praticadas pelos operadores.

Apesar de se ter chegado a uma conclusão sobre a causa do problema, temos que ressaltar que pouco foi feito até agora para uma melhora efetiva no setor de abastecimento de água. A problemática continua séria e, certamente, agravar-se-á cada vez mais podendo atingir em pouco tempo índices incontroláveis caso nada seja feito para resolvê-la ou minimizá-la. Sem dúvida, o poder público municipal deve se focar nesta questão em caráter emergencial. 


\section{9 - Aspectos técnicos: captação, tratamento e distribuição de água em Itu-SP}

\section{1 - Informações Gerais}

O setor de abastecimento de água no município de Itu-SP foi administrado pelo poder público municipal por meio do Serviço Autônomo de água e Esgoto de Itu (SAAE) até 2007. A autarquia foi instituída em 1972 e até o final do ano de 2007 administrou o serviço de água de Itu, quando por meio de um processo de concorrência pública realizado pela prefeitura, o serviço operacional foi concedido por trinta anos a uma empresa privada. Foi na administração do SAAE que o município enfrentou suas piores crises, inclusive no ano 2000 quando foi decretado estado de calamidade pública em Itu por conta da escassez de água para abastecimento público.

Desde a sua criação em 1972, o poder público local sempre fez questão que a administração dos serviços de água e esgoto ficasse a cargo do SAAE, evitou inclusive aderir ao PLANASA (Plano Nacional de Saneamento). O PLANASA foi instituído pelo governo brasileiro em 1971 e foi um instrumento criado para que os Estados brasileiros implementassem, em suas cidades, sistemas de abastecimento de água e de esgoto. Foram criadas, assim, companhias estaduais de saneamento básico às quais foram concedidos os sistemas de saneamento urbano. Com esta nova forma de gestão, os investimentos por parte do governo puderam ter condições de retorno, pois foram feitos a título de empréstimo (OGERA \& PHILIPPI JR, 2005).

Apesar de alguns problemas de ordem estrutural, o PLANASA pode ser considerado um plano bem sucedido da administração pública brasileira da época, pois, "em pouco mais de 20 anos foi possível estender os serviços de abastecimento de água e 
esgoto sanitário para cerca de 70 milhões de pessoas" (CNS, 1999, p.17). Sem ter aderido ao plano, os investimentos no setor de água e esgoto de Itu foram menores, ficando o SAAE dependente de suas próprias forças e, eventualmente, do repasse de verbas extras por parte do poder público municipal. Este fato pode ter sido um agravante na problemática em foco, contribuindo para a piora na qualidade dos serviços prestados pela autarquia nas últimas décadas. Devido às constantes crises pelas quais o SAAE passava nos últimos anos, o poder público municipal resolveu conceder o direito operacional do serviço de água e esgoto de Itu à iniciativa privada.

No final de 2007, depois de anos de discussão na câmara municipal de Itu e de um processo de concorrência pública, parte do SAAE foi concedida por trinta anos a uma organização privada intitulada "Águas de Itu", de propriedade de um grupo empresarial denominado Equipav S/A - Pavimentação, Engenharia e Comércio. Este grupo possui diversas empresas atuantes em vários ramos de atividade, além disso, administra setores que foram privatizados ou concedidos dentro do Programa Estadual de Desestatização e Parcerias com a iniciativa Privada, do Governo do estado de São Paulo. As discussões sobre a concessão do serviço de abastecimento público de água duraram anos, principalmente porque alguns setores do poder público apoiavam a idéia e outros não.

Em 2000, ocorreu a primeira votação na Câmara, todavia na ocasião a maioria dos vereadores votou pela continuidade da administração municipal no SAAE. Porém com o passar dos anos e com a visível piora na prestação de serviços, a concessão foi votada e aprovada pela maioria dos vereadores em Julho de 2007, e o sistema operacional de saneamento básico de Itu entregue para a administração privada em Outubro do mesmo ano. A partir daí, a empresa "Águas de Itu", vencedora da concorrência pública, assumiu as operações por trinta anos e prometeu melhorar significativamente a qualidade do 
serviço de água e esgoto municipal, tendo como desafio maior solucionar o problema do abastecimento público de água que há séculos aflige o município de Itu. Resta saber se isso realmente ocorrerá e, caso ocorra, qual será o preço a ser pago pela população local para ter um serviço eficiente e de qualidade.

Vale ressaltar que somente a parte operacional do serviço municipal de água e esgoto de Itu foi concedida a iniciativa privada, ficando o SAAE como agente regulador e fiscalizador do serviço de água enquanto durar a concessão. A maioria dos funcionários da autarquia foi transferida para setores da prefeitura ou optou por aderir ao Plano de Incentivo à Exoneração Voluntária (PIEV), enquanto uma minoria permaneceu prestando serviços na área de fiscalização.

Segundo informações do próprio SAAE (2008), o município de Itu conta com 42 mil ligações de água com uma malha de distribuição de 554 km (densidade de 13,2 m/lig), o que equivale a um índice de cobertura municipal de 93\% do sistema viário (Figura 13).

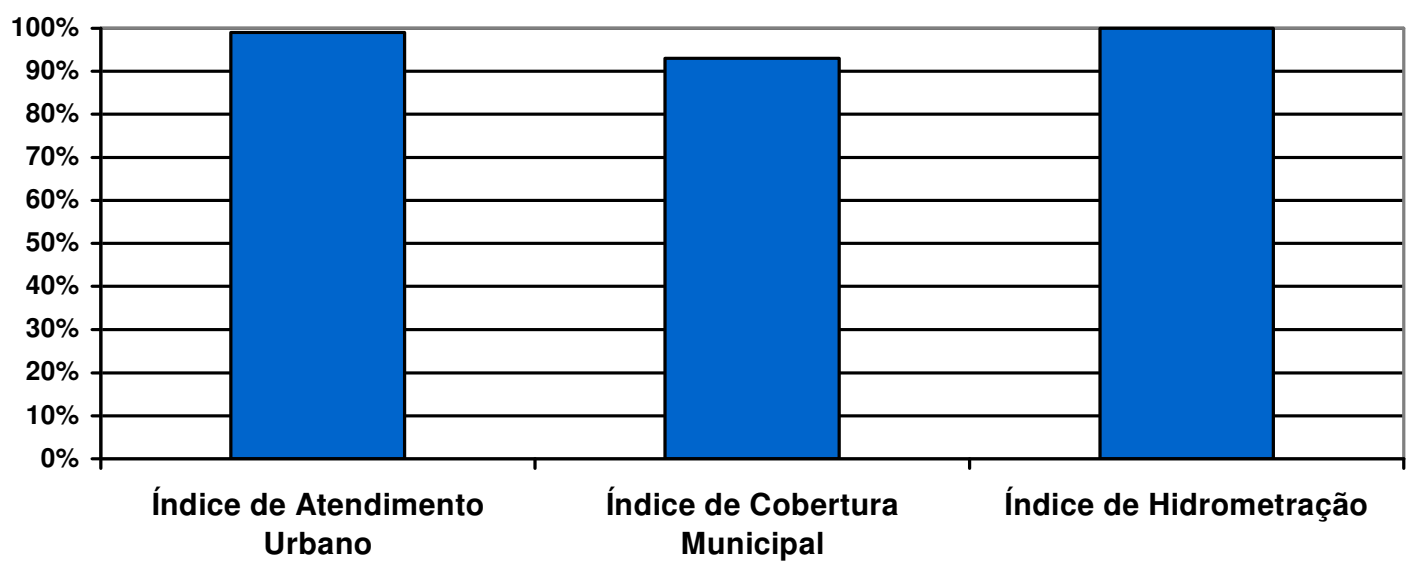

Figura 13 - Índices de atendimento urbano, cobertura municipal e hidrometração no município de Itu-SP.

Fonte: SAAE, 2008. Organizado por Rodrigues, 2008. 
O Serviço basicamente atende duas localidades diferentes, o núcleo urbano principal (sede) e o núcleo urbano secundário (Pirapitingui). As informações gerais sobre o sistema se encontram no quadro abaixo (Quadro 2)2:

Quadro 2 - Informações gerais sobre o sistema de captação, tratamento e distribuição de água do município de Itu-SP.

\begin{tabular}{|l|c|c|c|}
\hline \multicolumn{1}{|c|}{ Instalação } & Total & Sede & Pirapitingui \\
\hline Mananciais & 7 & 6 & 1 \\
importantes & & & 2 \\
\hline Captações & 7 & 5 & $2(111 \mathrm{l} / \mathrm{s})$ \\
\hline Estações de & $5(661 \mathrm{l} / \mathrm{s})$ & $350 \mathrm{l} / \mathrm{s})$ & \\
tratamento de água & & & - \\
(ETA's) & $99^{*}$ & $7{ }^{* *}$ & 9 unidades \\
\hline Poços utilizados & 41 unidades & 32 unidades & 3 \\
\hline Reservatórios & 11 & 8 & 8.000 \\
\hline Elevatórias & 48.200 & 40.200 & $\mathrm{Nd}$ \\
\hline Ligações & $554 \mathrm{~km}$ & $\mathrm{Nd}$ & \\
\hline Redes & & & \\
\hline
\end{tabular}

* sete estão localizados na sede e dois estão situados no Jardim Emicol (um pequeno bairro da zona rural do município). Há ainda oito poços desativados.

** Destes, três são utilizados somente em épocas de estiagem.

Fonte: SAAE, 2008. Organizado por Rodrigues, 2008.

${ }^{2}$ A planta com todas as instalações do SAAE de Itu encontra-se no CD em anexo. 


\section{2 - Captação}

Como já dito anteriormente, o município de Itu possui 14 microbacias hidrográficas sendo 12 pertencentes à bacia hidrográfica do Rio Tietê e 2 microbacias pertencentes à bacia hidrográfica do rio Sorocaba.

O Tietê é o principal rio do município, porém devido à poluição de suas águas não pode ser utilizado para abastecimento público. Entre os demais cursos de água que passam pelo município e que são utilizados para a captação no núcleo urbano principal podemos citar o Ribeirão Pirapitingui, Ribeirão Itaim Guaçú, Ribeirão Braiaiá, Córrego dos Gomes e Córrego São José (Quadro 3).

Quadro 3 - Mananciais utilizados para abastecimento público no núcleo urbano principal de Itu-SP

\begin{tabular}{|c|c|c|c|c|c|c|c|}
\hline \multirow{2}{*}{ Captação } & \multirow{2}{*}{$\begin{array}{l}\text { Área } \\
\left(\mathrm{km}^{2}\right)\end{array}$} & \multicolumn{4}{|c|}{ Vazão (I/s) } & \multirow{2}{*}{ ETA } & \multirow{2}{*}{ Problemas } \\
\hline & & Captada & $\mathbf{Q}_{\mathrm{m}}$ & $\mathbf{Q}_{95 \%}{ }^{\left({ }^{*}\right)}$ & $\mathbf{Q}_{7 / 10}{ }^{\left({ }^{* *}\right)}$ & & \\
\hline Pirapitingui & 76 & 330 & 749 & 270 & 151 & 1 & $\begin{array}{l}\text { Devastação de 50\% } \\
\text { da cobertura } \\
\text { vegetal. }\end{array}$ \\
\hline Itaim & 76 & 115 & 377 & 140 & 65 & 7 & $\begin{array}{l}\text { Devastação de } 80 \% \\
\text { da cobertura } \\
\text { vegetal. }\end{array}$ \\
\hline Braiaiá & 43 & 100 & 426 & 140 & 86 & 1 & $\begin{array}{l}\text { Devastação de } 70 \% \\
\text { da cobertura vegetal }\end{array}$ \\
\hline
\end{tabular}




\begin{tabular}{|l|c|c|c|c|c|c|l|}
\hline & & & & & & & $\begin{array}{l}\text { e proximidade do } \\
\text { aterro sanitário. }\end{array}$ \\
\hline Gomes & 17 & 45 & 162 & 60 & 33 & 1 & $\begin{array}{l}\text { Captação excessiva } \\
\text { de suas águas para } \\
\text { irrigação. }\end{array}$ \\
\hline São José & 9 & 25 & 97 & 35 & 20 & 5 & ------------------ \\
\hline Total & 215 & 560 & 1.811 & 519 & 364 & & \\
\hline
\end{tabular}

$\left.{ }^{*}\right)$ Vazão firme em $95 \%$ do tempo $\left(Q_{95 \%}\right)$;

$\left.{ }^{* *}\right)$ Vazão mínima provável em 7 dias consecutivos com 10 anos de recorrência $\left(Q_{7 / 10}\right)$.

Fonte: FGV, 2000. Organizado e atualizado por Rodrigues, 2007.

Cada curso de água tem a sua barragem de captação de onde após ser captada, a água segue para as estações de tratamento. A maioria destas barragens possui algum tipo de problema sendo que o mais comum é a pequena capacidade de armazenamento devido, principalmente, ao assoreamento. Em alguns casos a barragem mesmo sendo relativamente nova já se mostra insuficiente para ajudar a resolver o problema como é o caso da barragem de acumulação do Taquaral.

Inaugurada em 2004, esta barragem foi construída na tentativa de aumentar a disponibilidade de água para a represa do Fubaleiro, situada à jusante no Ribeirão Pirapitingui, e cujas águas abastecem a estação de tratamento (ETA) I. A intenção era minimizar o problema da escassez nesta estação em épocas de estiagem, mas logo após a sua inauguração ela já se mostrou incapaz de ajudar a solucionar este problema, principalmente porque sua capacidade de armazenamento é pequena em comparação à quantidade captada na barragem do Fubaleiro e necessária para abastecer a ETA I. 
As imagens a seguir (Figuras: 14, 15, 16, 17 e 18), mostram a barragem de acumulação do Taquaral no Sábado dia 3 de Novembro de 2007 com níveis mínimos, na ocasião o município enfrentava novamente a rotina dos racionamentos diários. Vale ressaltar que no ano em questão problema da escassez de água para abastecimento público começou em Julho, atingiu o seu auge nos meses de Setembro e Outubro (anexo 2) e terminou em Dezembro.

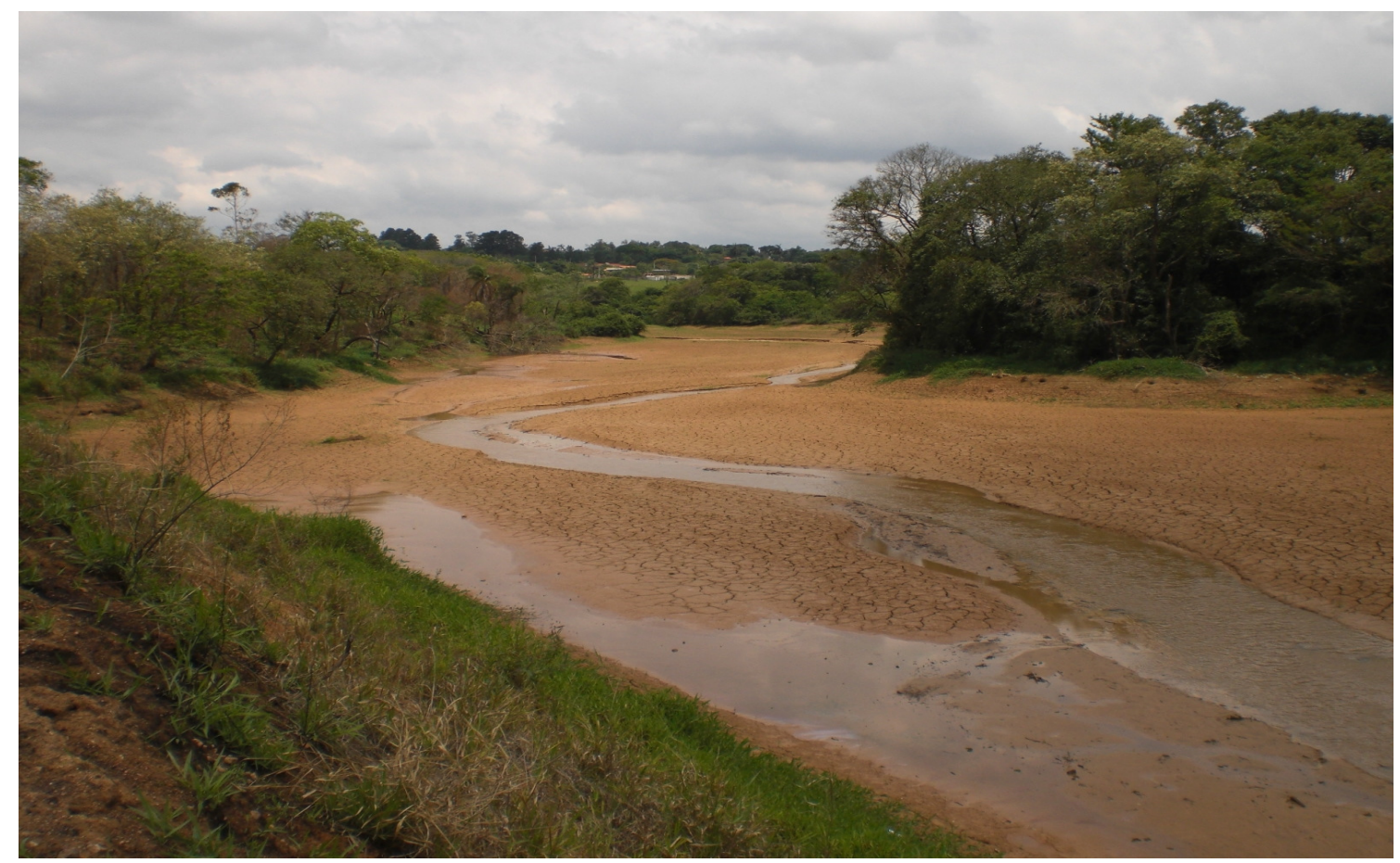

Figura 14 - Barragem de acumulação do Taquaral com níveis mínimos no dia 3/11/07. Fonte: Rodrigues, 2007. 


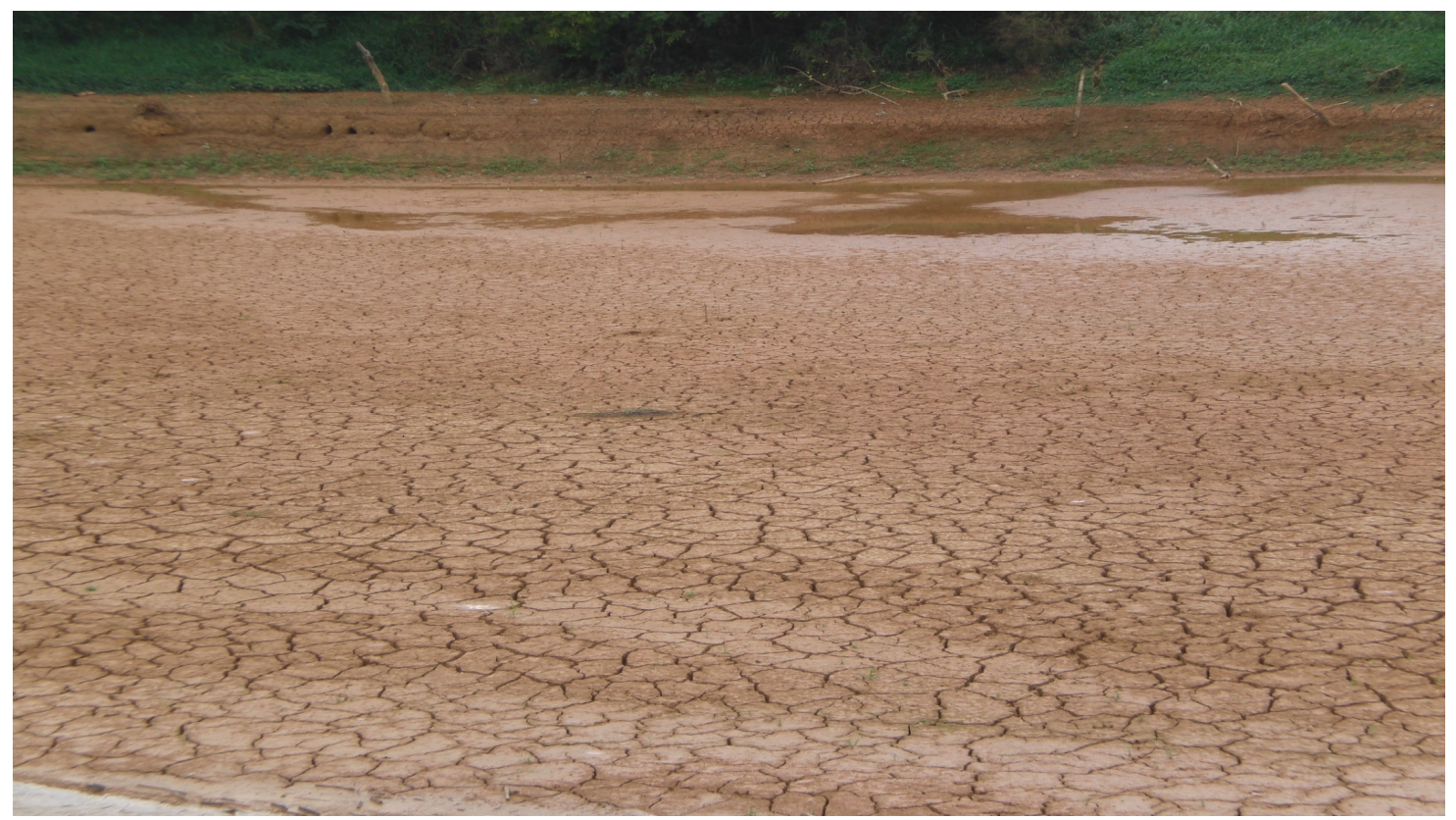

Figura 15 - Barragem de acumulação do Taquaral com níveis mínimos no dia 3/11/07. Fonte: Rodrigues, 2007.

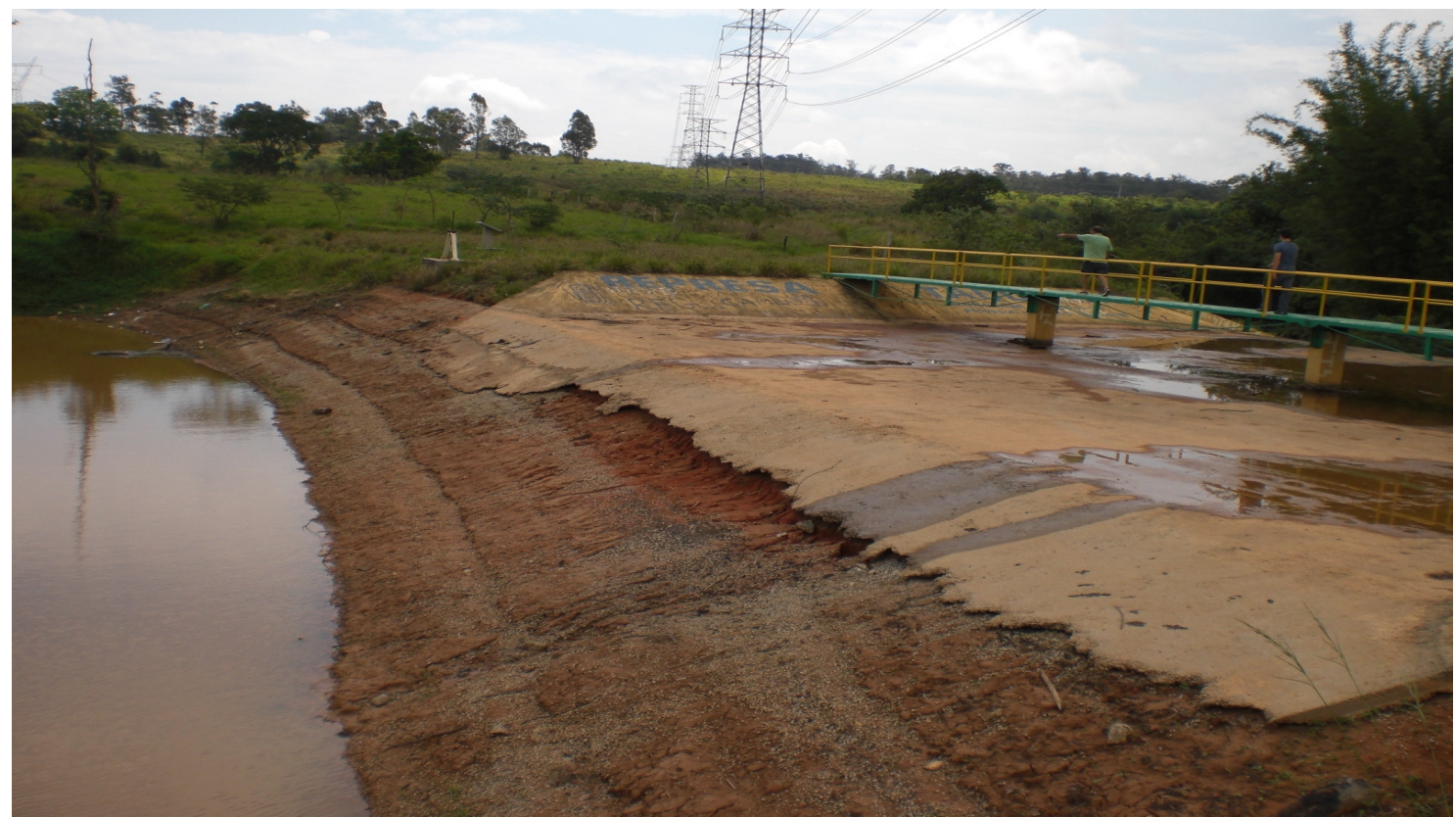

Figura 16 - Barragem de acumulação do Taquaral com níveis mínimos no dia 3/11/07. Fonte: Rodrigues, 2007. 


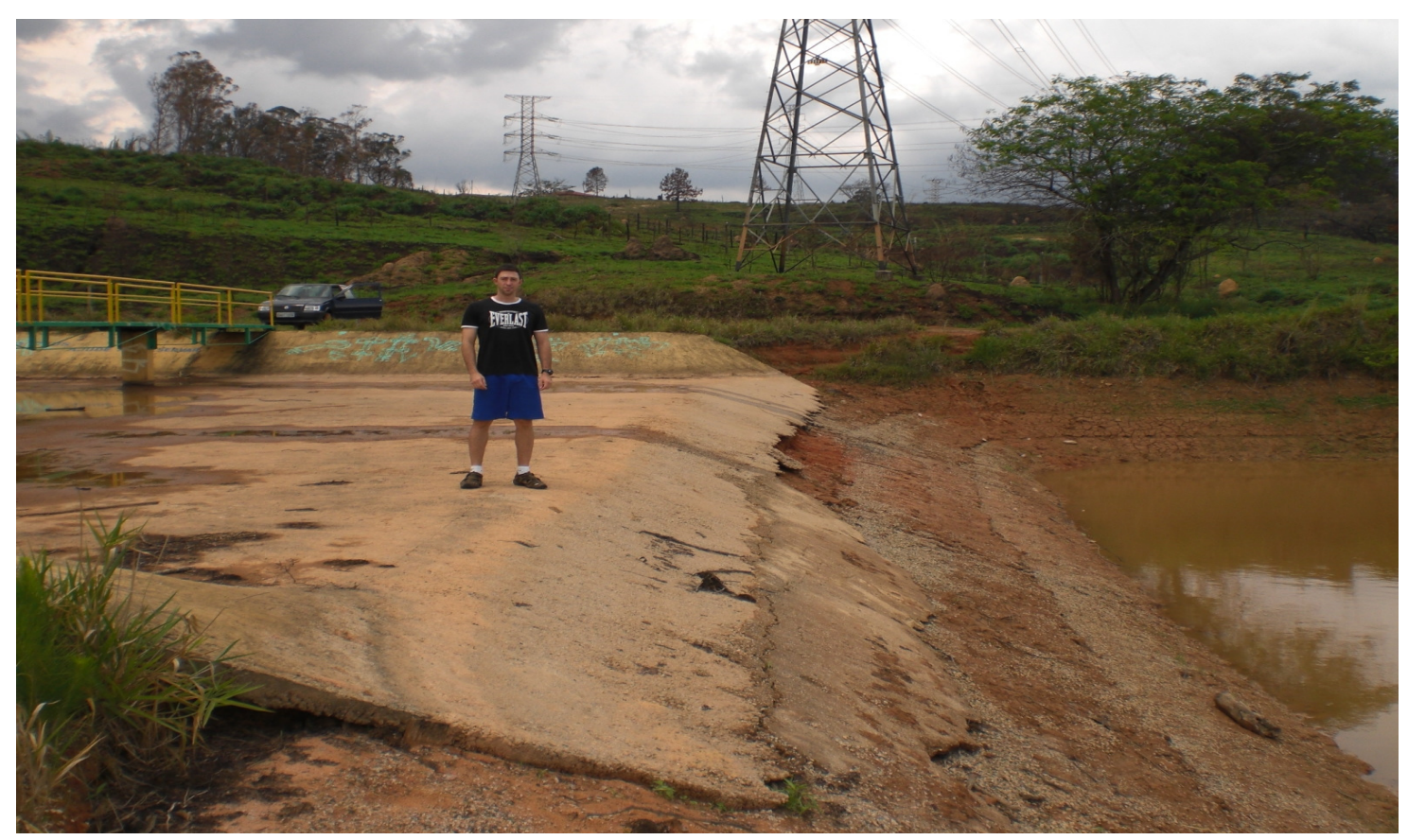

Figura 17 - Barragem de acumulação do Taquaral com níveis mínimos no dia 3/11/07. Fonte: Rodrigues, 2007.

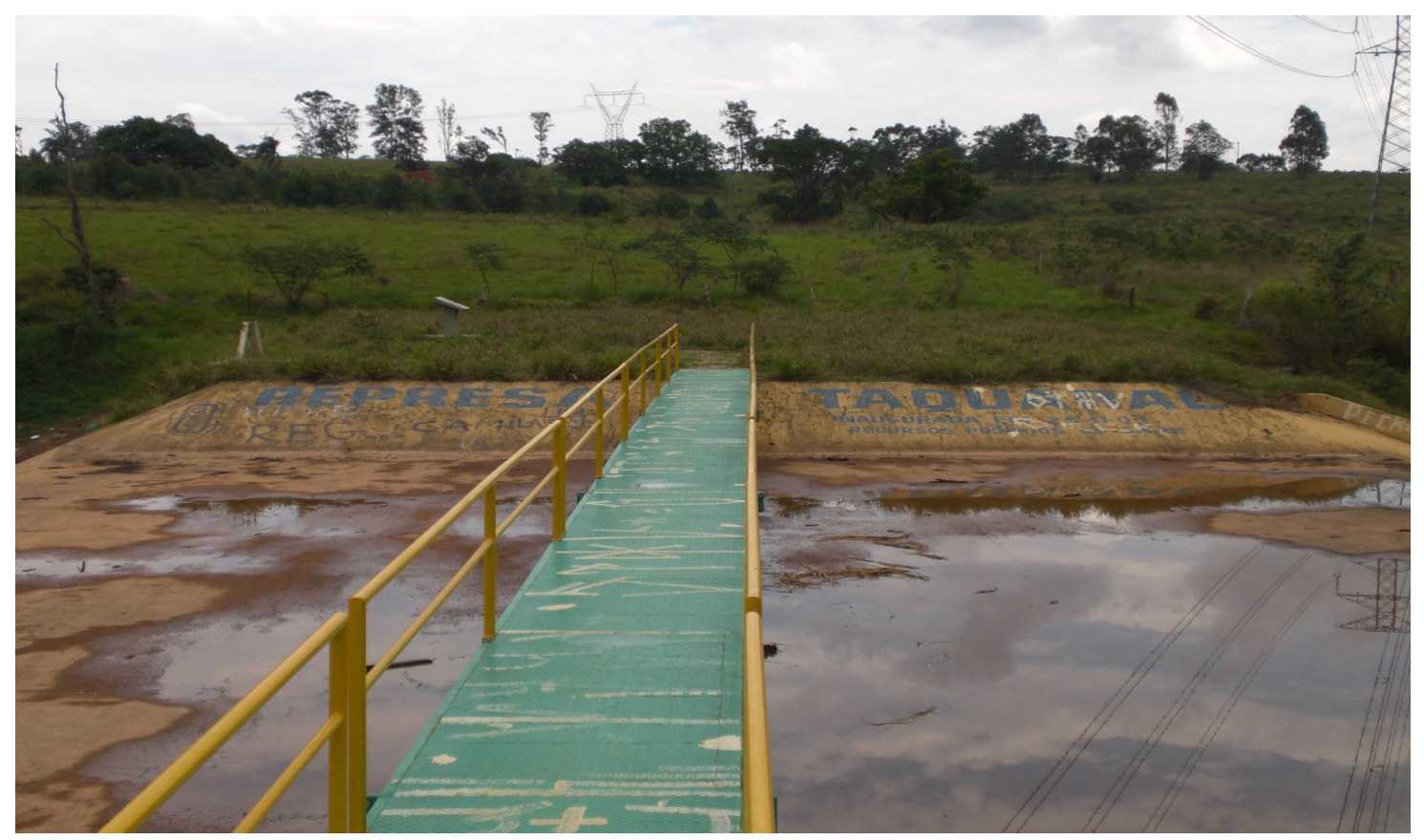

Figura 18 - Barragem de acumulação do Taquaral com níveis mínimos no dia 3/11/07. Fonte: Rodrigues, 2007. 
As imagens a seguir (figuras 19, 20, 21, 22 e 23) mostram a mesma barragem na Quarta-feira dia 6 de Novembro de 2007 com volume de armazenamento máximo. É de suma importância ressaltar que entre o dia 3 e o dia 6 caíram na região 55 mm de chuva, o que foi suficiente para encher a barragem e ainda liberar água, pois a capacidade de armazenamento havia chegado ao limite.

Isso nos leva a crer que a capacidade de armazenamento de água da mais nova barragem que o município possui é pequena, bem abaixo do esperado para uma barragem construída no intuito de minimizar o problema da escassez de água em Itu. Se a barragem fosse maior e mais profunda, o aproveitamento das águas pluviais teria sido bem maior do que o verificado e aí sim a disponibilidade de água para a ETA I seria significativa.

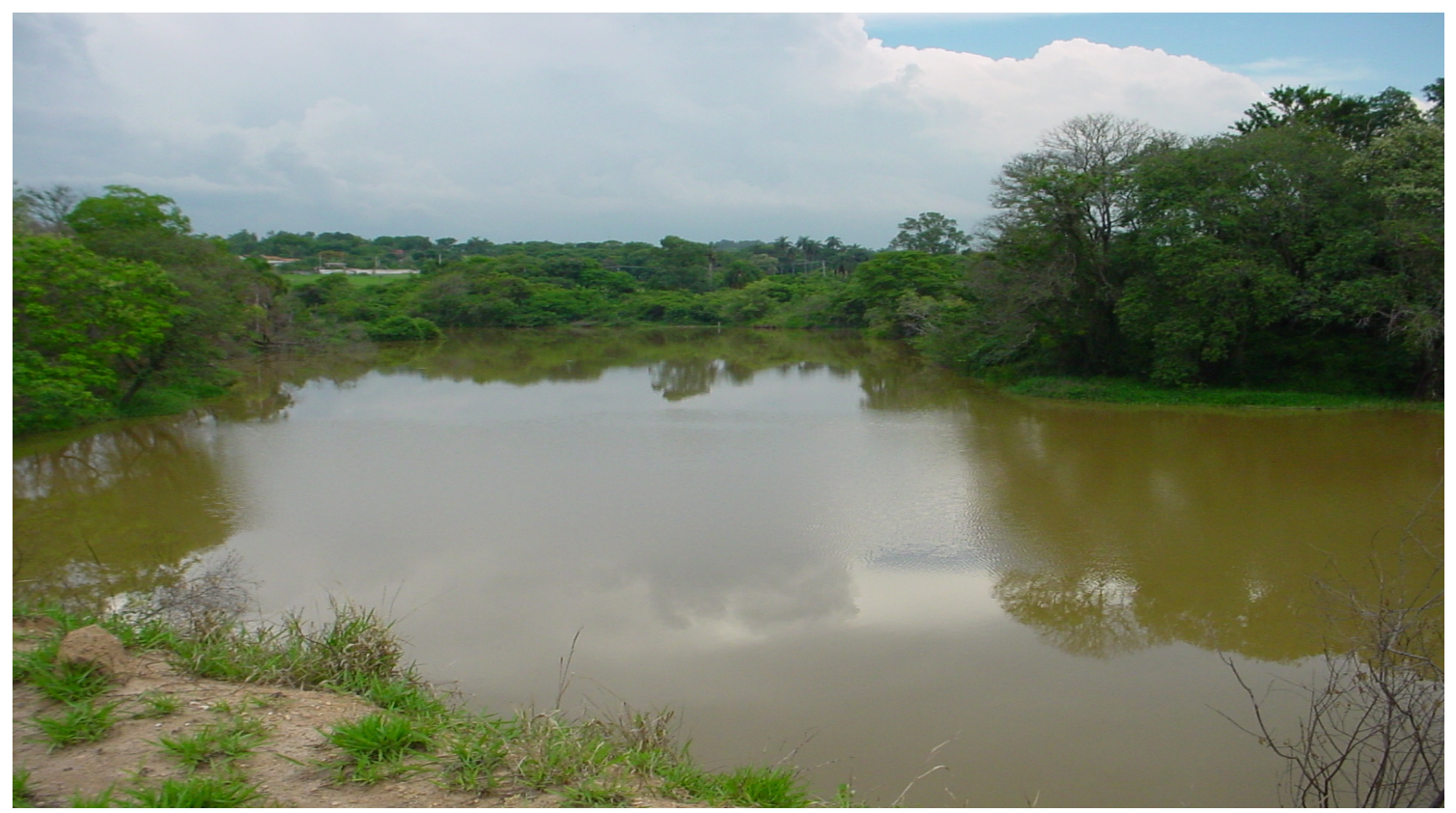

Figura 19 - Barragem de acumulação do Taquaral com volume de armazenamento máximo no dia 6/11/07.

Fonte: Rodrigues, 2007. 

socioeconômicos no município de Itu-SP.

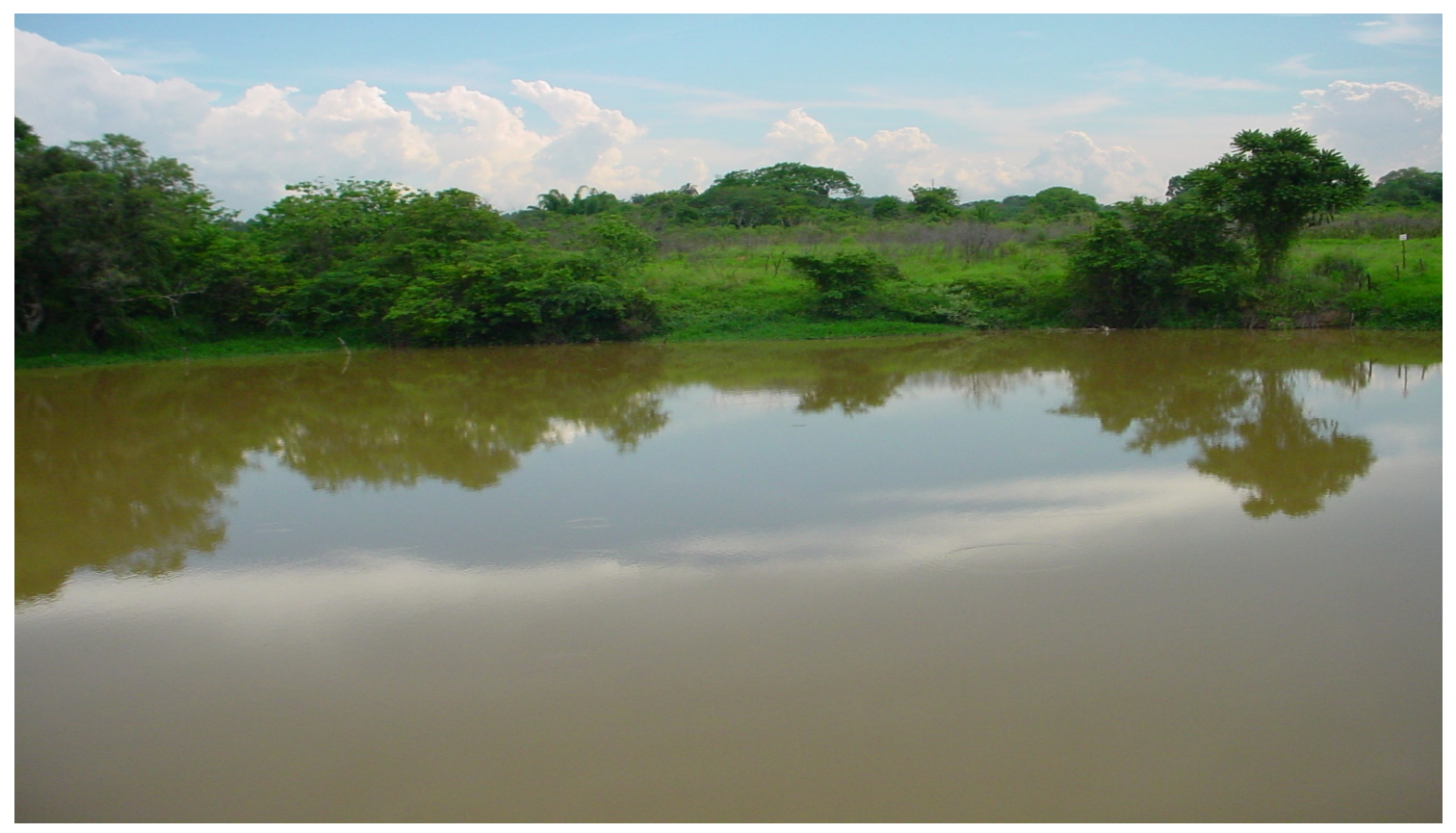

Figura 20 - Barragem de acumulação do Taquaral com volume de armazenamento máximo no dia 6/11/07.

Fonte: Rodrigues, 2007.

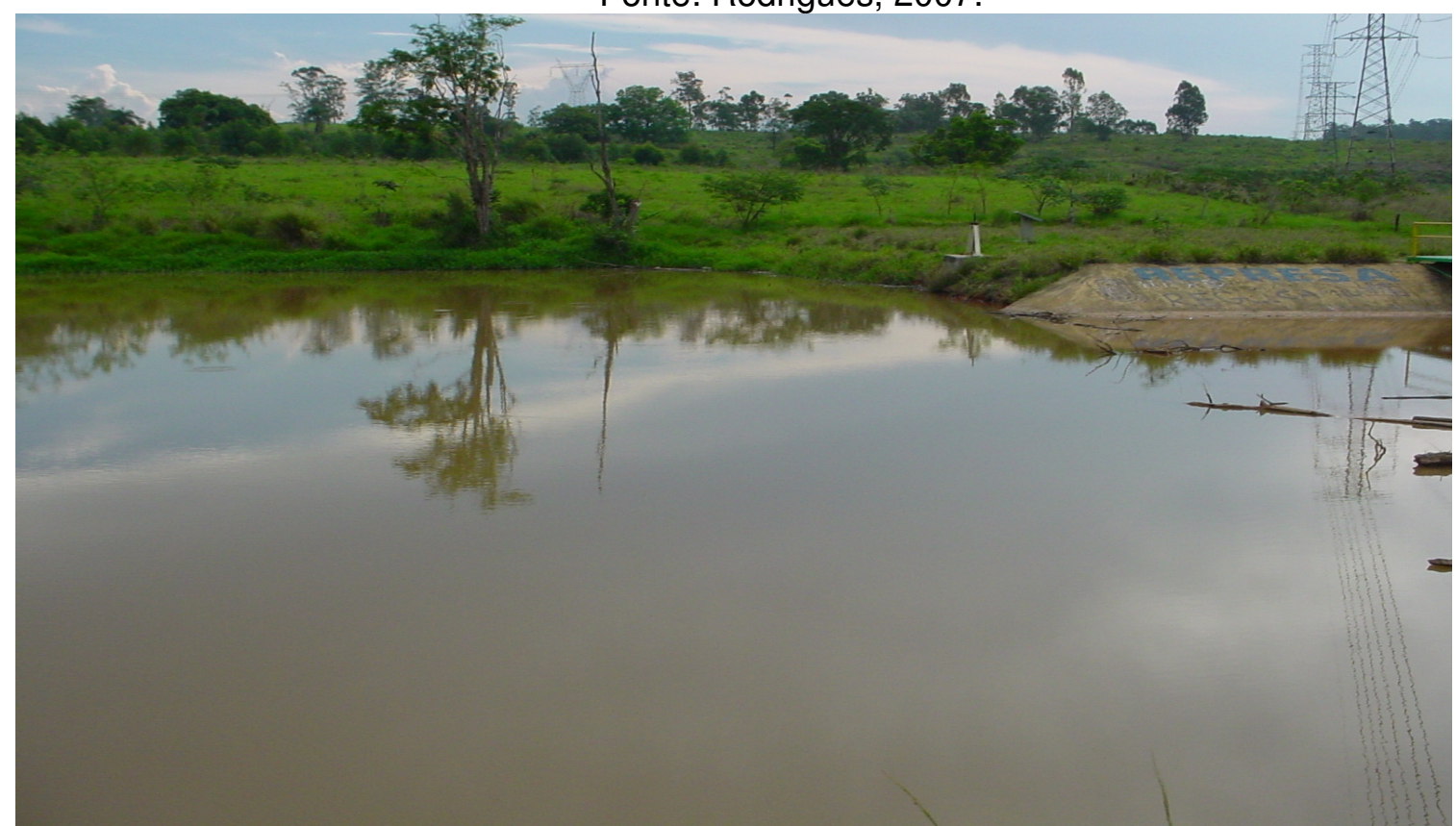

Figura 21 - Barragem de acumulação do Taquaral com volume de armazenamento máximo no dia 6/11/07.

Fonte: Rodrigues, 2007. 


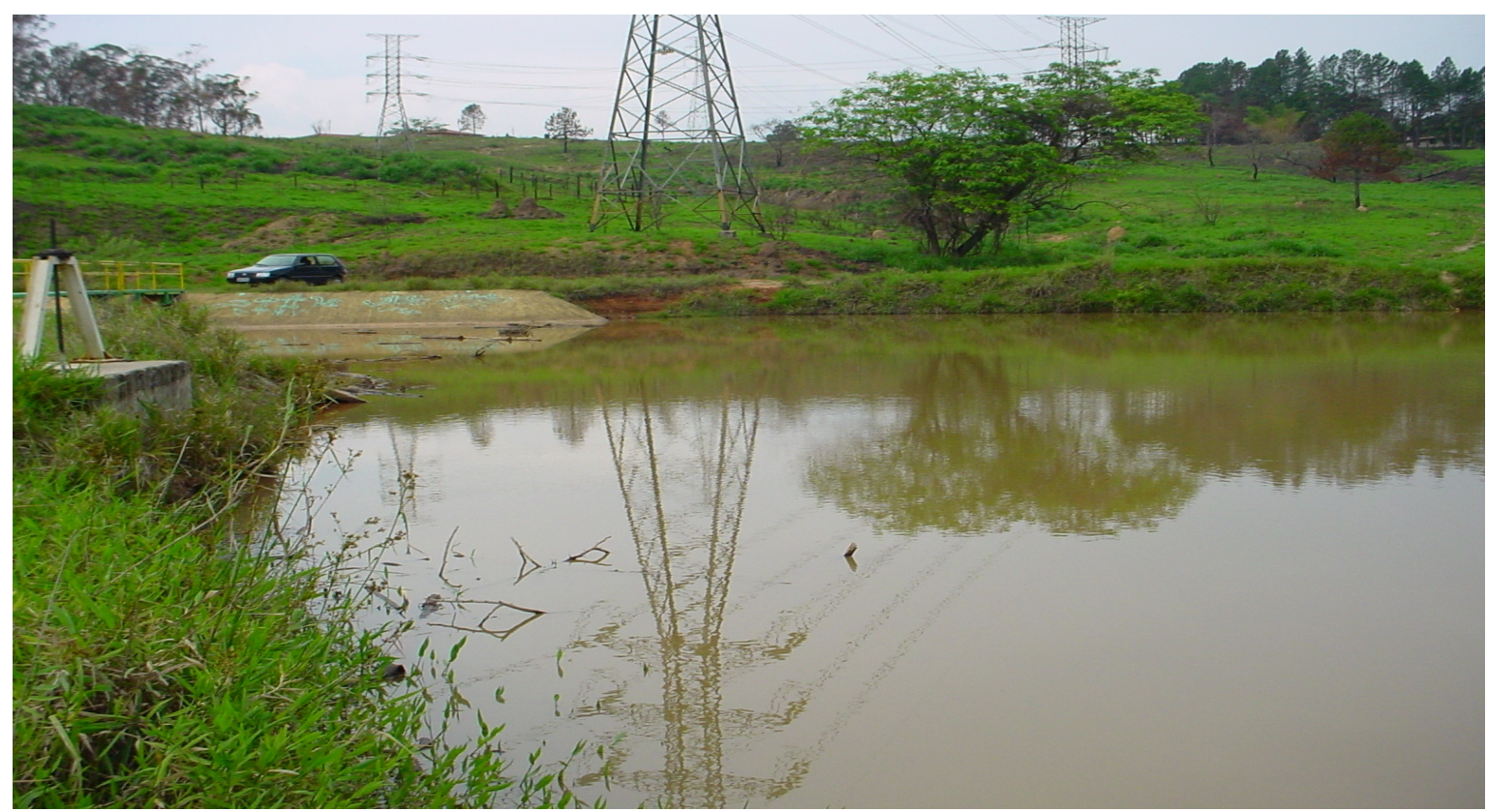

Figura 22 - Barragem de acumulação do Taquaral com volume de armazenamento máximo no dia 6/11/07.

Fonte: Rodrigues, 2007.

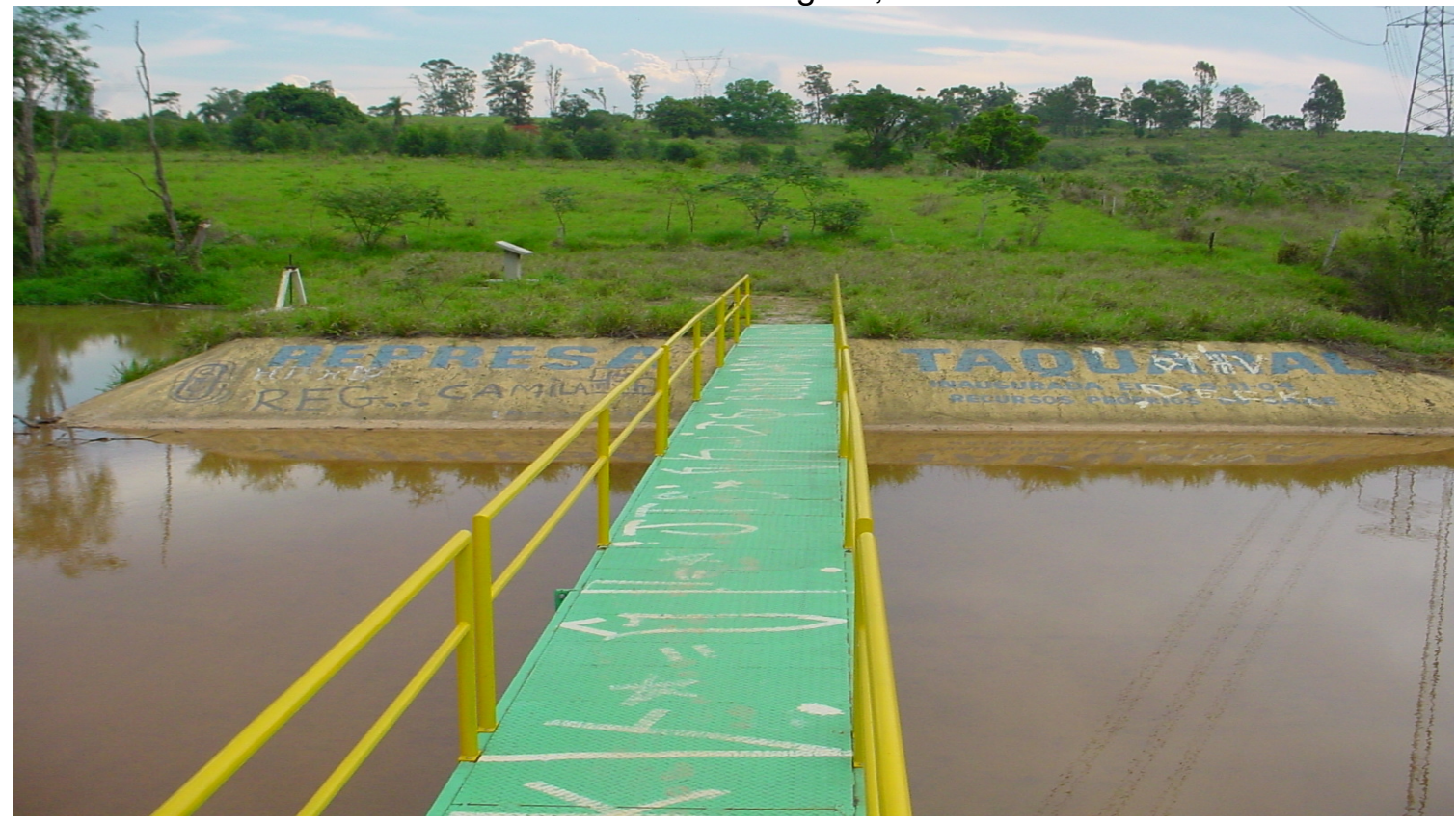

Figura 23 - Barragem de acumulação do Taquaral com volume de armazenamento máximo no dia 6/11/07.

Fonte: Rodrigues, 2007. 
A barragem de captação do Itaim, localizada no ribeirão de mesmo nome, é um outro exemplo de barragem que possui uma capacidade de armazenamento pequena.

Ela é responsável por fornecer água para a ETA VII, esta estação por sua vez é responsável por tratar e distribuir água para as regiões oeste e noroeste do núcleo urbano principal de Itu. Nas imagens a seguir nos deparamos com os mesmos acontecimentos verificados na barragem de acumulação do Taquaral, as figuras 24 e 25 mostram a barragem do Itaim, também no dia 3 de Novembro de 2007, com o volume de armazenamento reduzido. É importante lembrar que na ocasião dos fatos a cidade passava por um forte racionamento, os moradores só possuíam água durante a madrugada. A explicação do poder público municipal era a escassez de água na região da captação.

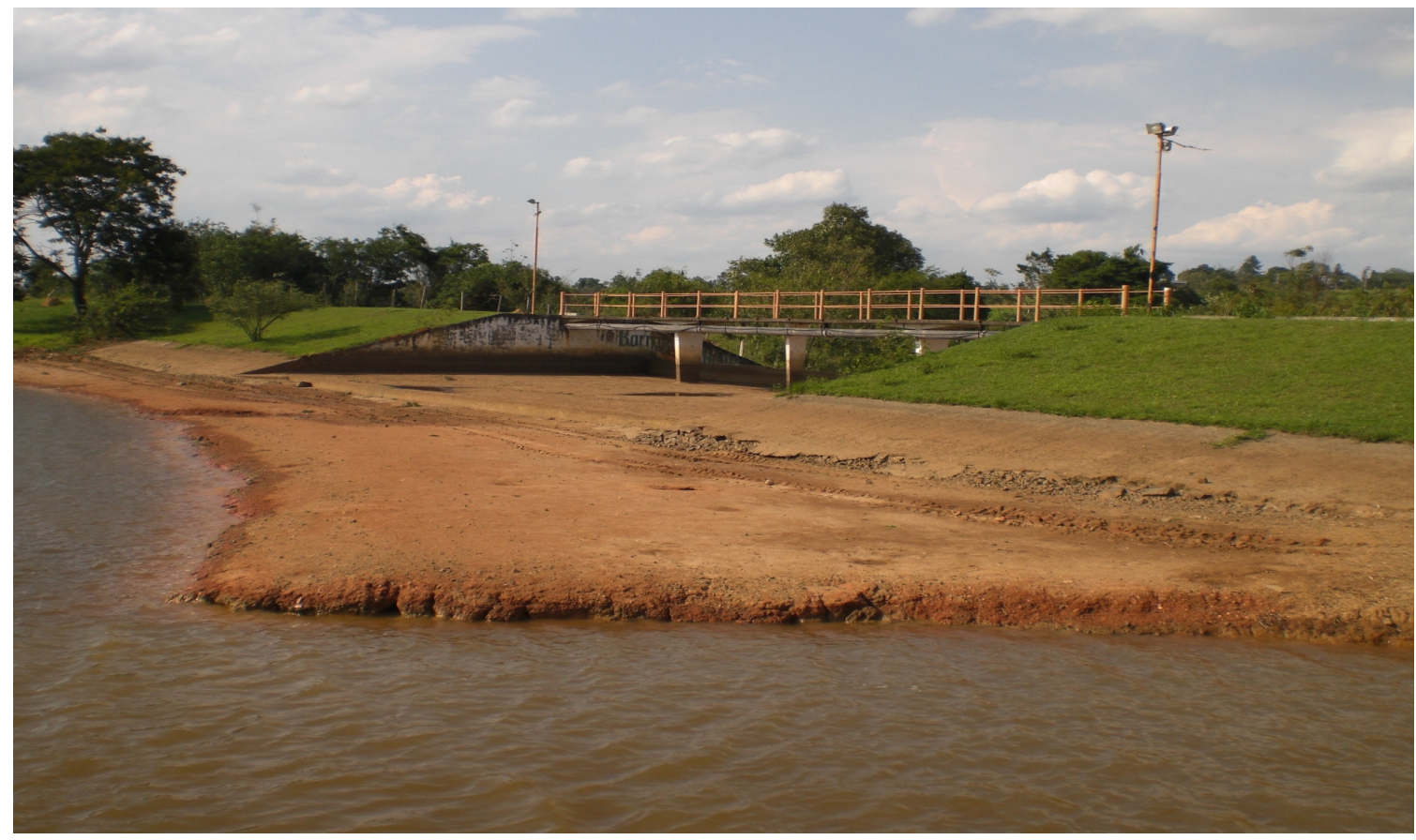

Figura 24 - Barragem de captação do Itaim com volume de armazenamento reduzido no dia $3 / 11 / 07$.

Fonte: Rodrigues, 2007. 


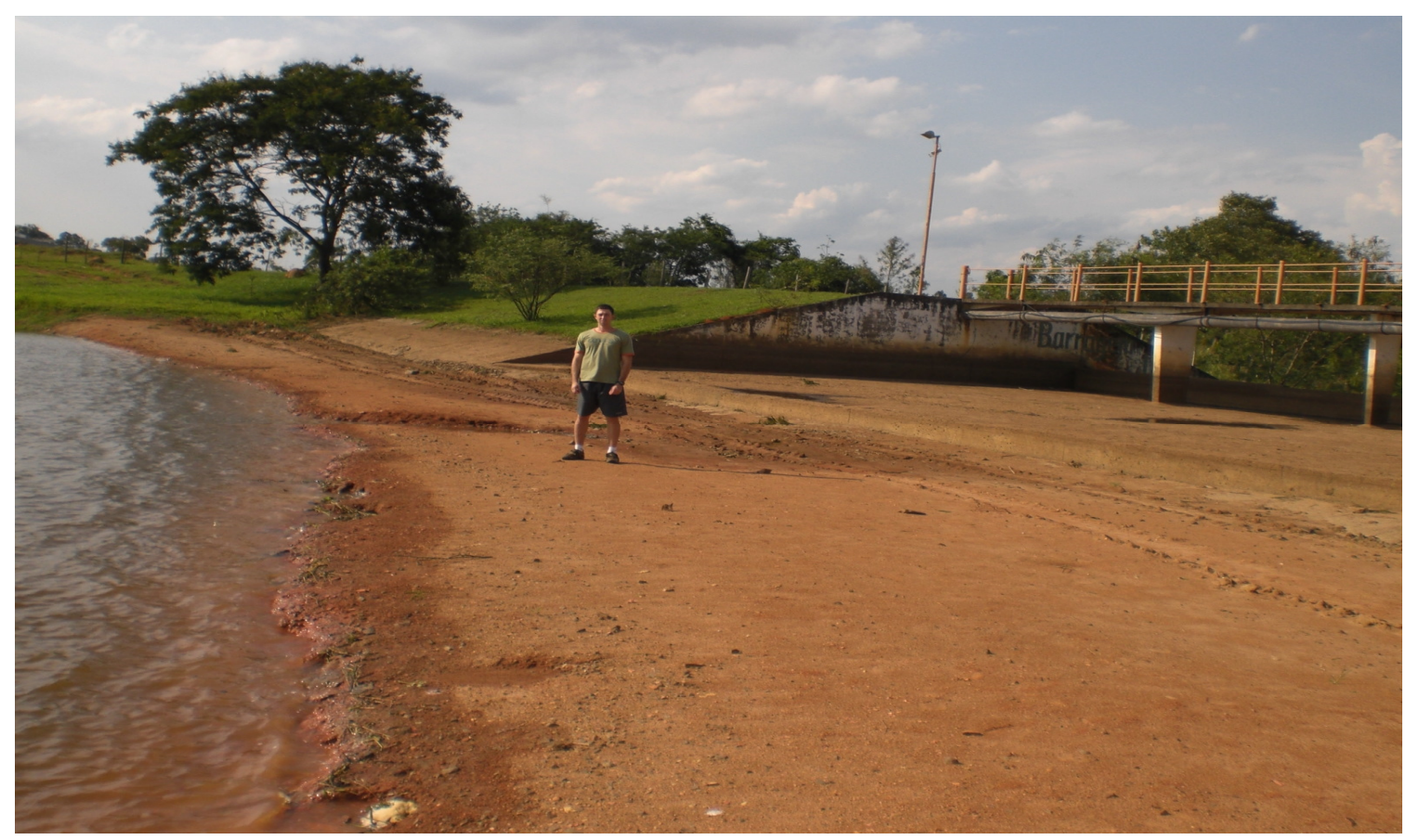

Figura 25 - Barragem de captação do Itaim com volume de armazenamento reduzido no dia $3 / 11 / 07$.

Fonte: Rodrigues, 2007.

Já no dia 6 de Novembro de 2007 a barragem estava com seu volume de armazenamento máximo (figuras 26 e 27).

Considerando que entre os dias 3 e 6 de Novembro de 2007 (período das fotos) a precipitação foi de $55 \mathrm{~mm}$, o volume foi suficiente para encher os principais reservatórios do município que antes operavam bem abaixo do normal. Pode-se notar a precariedade dos reservatórios uma vez que são pequenos, rasos e com pouca capacidade de armazenamento de água. No caso específico do Itaim, a última obra de recuperação e desassoreamento foi realizada no ano de 2002 (figura 28), após esta data nenhuma outra obra significativa foi feita no intuito de aprofundar ou alargar o reservatório. 


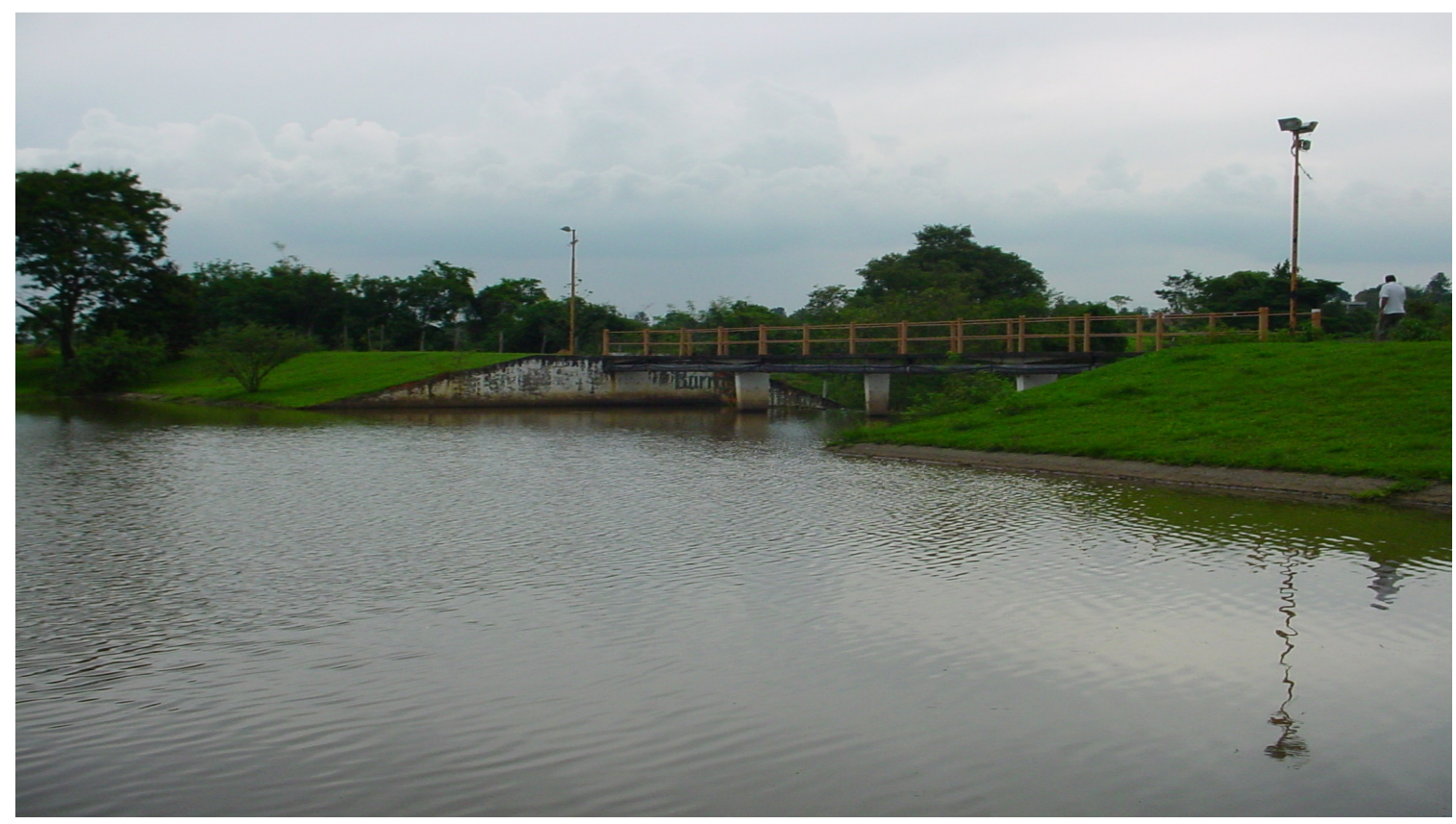

Figura 26 - Barragem de captação do Itaim com níveis máximos no dia 6/11/07. Fonte: Rodrigues, 2007.

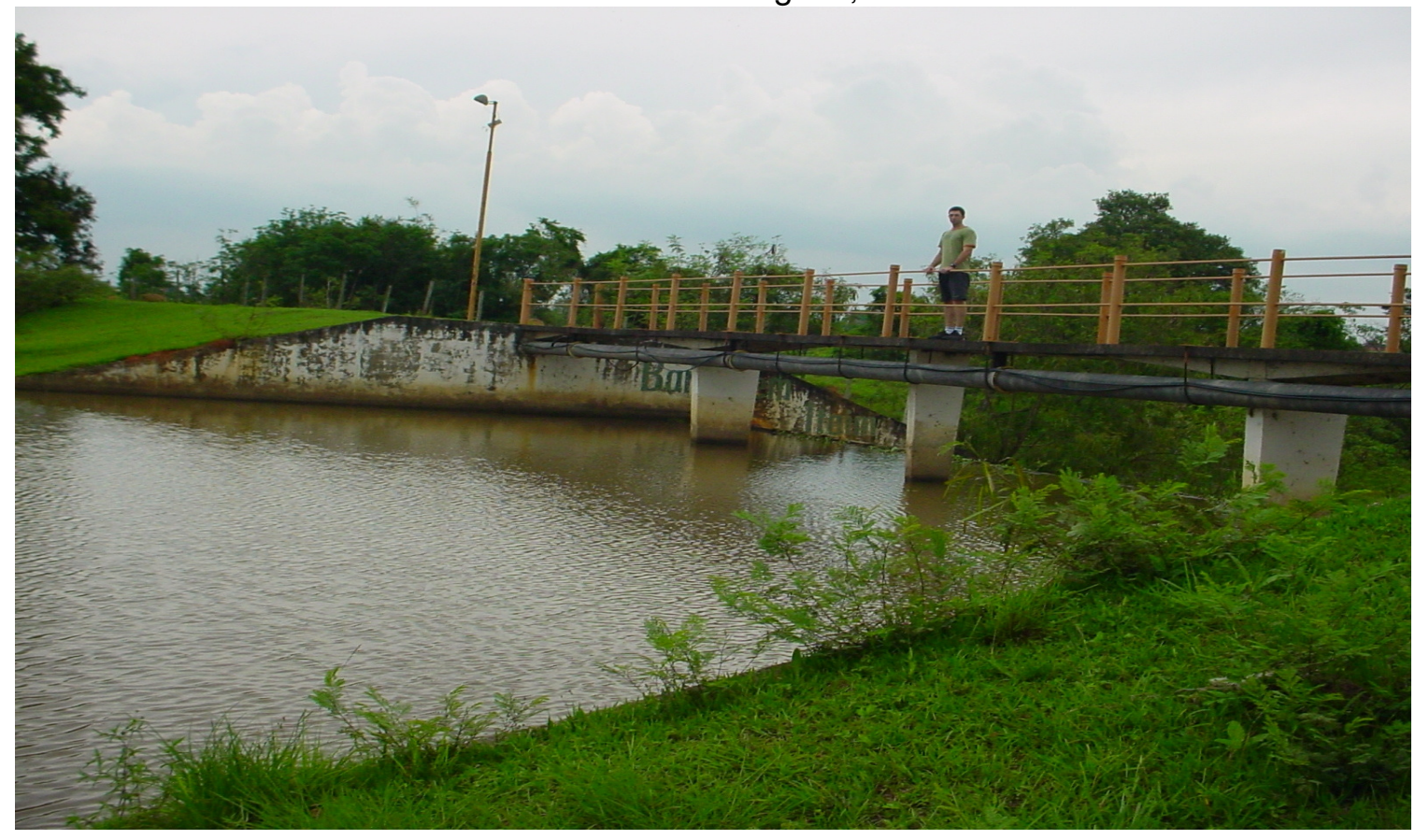

Figura 27 - Barragem de captação do Itaim com níveis máximos no dia 6/11/07. Fonte: Rodrigues, 2007. 


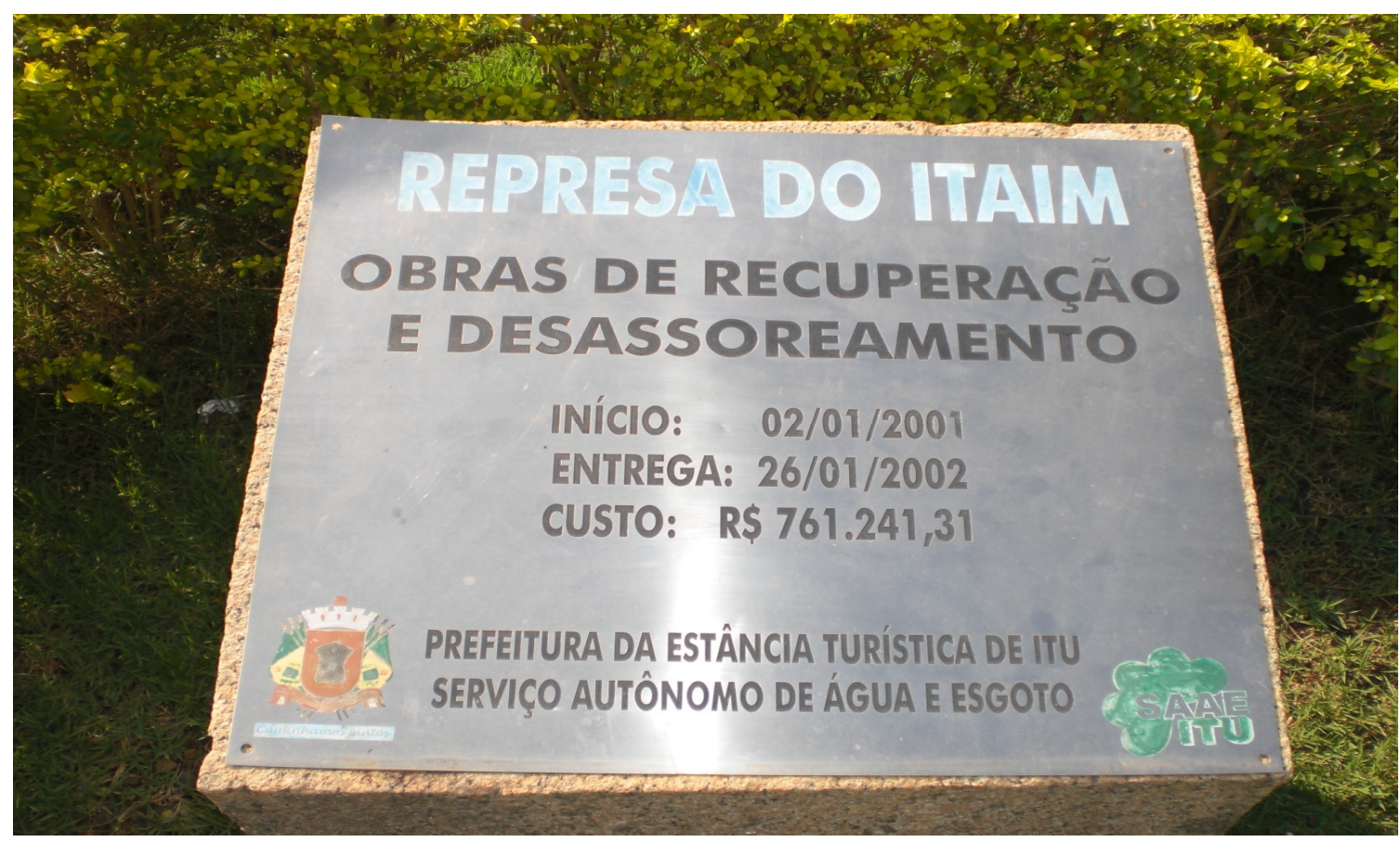

Figura 28 - Placa indicando o início e o término das últimas obras de recuperação e desassoreamento realizadas na barragem de captação do Itaim.

Fonte: Rodrigues, 2007.

Com relação ao núcleo urbano secundário do Pirapitingui, o manancial utilizado para abastecimento público é o Ribeirão Varejão (Quadro 4).

Quadro 4 - Manancial utilizado para abastecimento público no núcleo urbano secundário do Pirapitingui em Itu-SP

\begin{tabular}{|c|c|c|c|c|c|c|c|}
\hline \multirow{2}{*}{ Captação } & \multirow{2}{*}{$\begin{array}{l}\text { Área } \\
\left(\mathbf{k m}^{2}\right)\end{array}$} & \multicolumn{4}{|c|}{ Vazão (I/s) } & \multirow{2}{*}{ ETA } & Problemas \\
\cline { 3 - 6 } & Captada & $\mathbf{Q}_{\mathbf{m}}$ & $\mathbf{Q}_{95 \%}$ & $\mathbf{Q}_{\mathbf{7 / 1 0}}$ & & \\
\hline Ribeirão Varejão & 41 & 96 & 410 & 150 & 82 & 3 e 8 & Poluição por \\
esgoto doméstico
\end{tabular}




\begin{tabular}{|l|c|c|c|c|c|c|c|}
\hline Total & 41 & 96 & 410 & 150 & 82 & & \\
\hline
\end{tabular}

Fonte: FGV, 2000. Organizado por Rodrigues, 2007.

Além dos mananciais que já são utilizados para o abastecimento público existem ainda quatro outros mananciais passíveis de captação, o Piragibú, o Piraí, o Pau D’Alho, e o Mombaça (Quadro 5).

Quadro 5 - Mananciais Passíveis de Aproveitamento no Município de Itu-SP

\begin{tabular}{|c|c|c|c|c|c|c|c|}
\hline \multirow{2}{*}{ Captação } & \multirow{2}{*}{$\begin{array}{l}\text { Área } \\
\left(\mathrm{km}^{2}\right)\end{array}$} & \multicolumn{4}{|c|}{ Vazão (I/s) } & \multirow{2}{*}{ Objetivo } & \multirow{2}{*}{ Obs } \\
\hline & & Captada & $\mathbf{Q}_{\mathrm{m}}$ & $\mathbf{Q}_{95 \%}$ & $\mathbf{Q}_{7 / 10}$ & & \\
\hline Piragibú & 200 & 132 & - & - & 400 & Pirapitingui & ------------------- \\
\hline Piraí & 130 & 30 a 60 & - & - & 260 & Sede & $\begin{array}{l}\text { Via São José. } \\
\text { Disputa com } \\
\text { outros } \\
\text { municípios. }\end{array}$ \\
\hline Pau D’Alho & 19 & 30 & - & - & 38 & Sede & $\begin{array}{l}\text { Via Braiaiá ou } \\
\text { Gomes }\end{array}$ \\
\hline Mombaça & 216 & nd & 2.140 & - & 432 & Sede & $\begin{array}{l}\text { Via Braiaiá ou } \\
\text { Pirapitingui. }\end{array}$ \\
\hline
\end{tabular}

Fonte: FGV, 2000. Organizado por Rodrigues, 2007. 
O mais importante é o Piraí (noroeste do município) com possibilidade de transposição para a Bacia do São José, manancial da sede. O Piraí é o principal manancial das cidades de Salto e Indaiatuba, e ultimamente foco de disputas uma vez que estes municípios localizados a jusante do manancial não aceitam a idéia de que Itu (a montante) passe também a captar água do mesmo. Essa prática diminuiria muito o volume de água do rio principalmente nas épocas de estiagem.

O município é pobre em água subsuperficial, pois não possui no seu subsolo água em quantidades significativas para boas captações. Existem dezessete poços perfurados pelo poder público (Quadro 6), mas apenas nove são utilizados pelo SAAE. Destes, dois são usados continuamente para atender a um bairro rural de pequena dimensão (Jardim Emicol 1 e 2) e três são utilizados para abastecer o núcleo urbano principal nas épocas de estiagem (Jardim Paraíso 1-1 e 1-2 e Terras de São José). Apenas quatro poços são utilizados continuamente no núcleo urbano principal (Fubaleiro, Jardim Paraíso 2, Portal de Itu e Vila Santa Teresinha). A vazão média dos postos em funcionamento contínuo na sede é de $10.7 \mathrm{~m}^{3} / \mathrm{h}$ e a maior produção é de $17 \mathrm{~m}^{3} / \mathrm{h}$ (Fubaleiro).

Os outros oito poços existentes não estão em condições de funcionamento, sobretudo por apresentarem problemas técnicos e baixa vazão.

Quadro 6 - Total de poços da prefeitura no município de Itu-SP

\begin{tabular}{|c|c|c|c|c|}
\hline Poço & Local & Vazão $\left(\mathbf{m}^{\mathbf{3}} / \mathbf{h}\right)$ & Situação & Bomba \\
\hline P1 & Vila Santa & 4 & operando & EBARA JBHS 222-18 \\
& Teresinha & & & \\
\hline
\end{tabular}




\begin{tabular}{|c|c|c|c|c|}
\hline P2 & $\begin{array}{c}\text { Bairro } \\
\text { Progresso }\end{array}$ & 8 & desativado & $\mathrm{Nd}$ \\
\hline P3 & Fubaleiro & 17 & operando & KSB UPA $10011-13$ \\
\hline $\mathrm{P} 4$ & $\begin{array}{c}\text { Jardim Paraíso } \\
1-1\end{array}$ & 11 & $\begin{array}{c}\text { utilizado na } \\
\text { estiagem }\end{array}$ & CRI S4S 8-25 \\
\hline P5 & $\begin{array}{c}\text { Jardim Emicol } \\
1\end{array}$ & 7 & operando & KSB UPA 100B \\
\hline P6 & Sete Quedas 1 & 3 & desativado & $\mathrm{Nd}$ \\
\hline P7 & Sete Quedas 2 & 3 & desativado & EBARA BHS 411-11 \\
\hline P8 & $\begin{array}{c}\text { Jardim Paraíso } \\
2\end{array}$ & 15 & operando & KSB UPA 100 B7-11 \\
\hline P9 & $\begin{array}{c}\text { Residencial } \\
\text { Araguaia }\end{array}$ & 3 & desativado & KSB UPA 100B \\
\hline P10 & Jardim Emicol 2 & 4 & operando & KSB UPA 100B 4-21 \\
\hline P11 & Sete Quedas 3 & 2 & desativado & LEÂO 4R4-24 \\
\hline P12 & Portal de Itu & 7 & operando & EBARA BHS 412-18 \\
\hline P13 & $\begin{array}{c}\text { Jardim Paraíso } \\
1-2\end{array}$ & 6 & $\begin{array}{c}\text { utilizado na } \\
\text { estiagem }\end{array}$ & EBARA BHS 411-14 \\
\hline P14 & $\begin{array}{c}\text { Terras de São } \\
\text { José }\end{array}$ & 18 & $\begin{array}{c}\text { utilizado na } \\
\text { estiagem }\end{array}$ & EBARA \\
\hline P15 & $\begin{array}{l}\text { Campos de } \\
\text { Santo Antônio }\end{array}$ & 0.5 & desativado & EBARA BHS 511-10 \\
\hline P16 & Plaza Athenee & 7 & desativado & EBARA \\
\hline
\end{tabular}




\begin{tabular}{|c|c|c|c|c|}
\hline & & & & \\
\hline P17 & Jardim & 2 & desativado & $\mathrm{Nd}$ \\
& Convenção & & & \\
\hline
\end{tabular}

Fonte: SAAE, 2008. Organizado por Rodrigues, 2008.

No município é comum a abertura de poços privados, não em razão de tarifa, mas pela situação crônica de falta de água na época de estiagem. Não há nenhum controle destes poços, o que ameaça a integridade do aqüífero subterrâneo (UNIEMP, 2006, p.10).

\section{3 - Tratamento}

Atualmente o sistema de tratamento de água do município de Itu é composto por cinco estações de tratamento de água (ETA's) sendo elas ETA I (Rancho Grande), ETA III (Portal do Éden), ETA V (Paraíso), ETA VII (Itaim) e ETA VIII (Hospital do Pira). As ETA's II (Santo Antônio), IV (Flórida) e VI (Santa Inês) foram desativadas por corte de gastos, má qualidade da água e baixo rendimento respectivamente. As estações I, V e VII servem o núcleo urbano principal enquanto as estações III e VIII servem o núcleo urbano secundário do Pirapitingui.

A ETA I é a maior estação de tratamento de água do município, e abastece cerca de $75 \%$ da área urbana principal. É composta por um sistema denominado "velho" com o tratamento de $510 \mathrm{l} / \mathrm{s}$ e um sistema chamado "novo" com uma capacidade de tratamento 
$510 \mathrm{l} / \mathrm{s}$ podendo ser ampliada para $700 \mathrm{l} / \mathrm{s}$. Ambas são estações com processo de floculação, decantação e filtragem chamados "convencionais". (Quadro 7).

Quadro 7 - Características dos processos de tratamento de água da ETA I (Rancho Grande).

\begin{tabular}{|c|c|c|c|c|}
\hline ETA & Unidades & Tipo & $\begin{array}{l}\text { Área ou } \\
\text { Volume }\end{array}$ & $\begin{array}{c}\text { Capacidade } \\
(\mathrm{I} / \mathrm{s})\end{array}$ \\
\hline \multicolumn{5}{|l|}{ ETA I (parte velha) } \\
\hline$\checkmark$ Filtro & 6 & $\begin{array}{l}\text { Filtro rápido de fluxo } \\
\text { descendente,dupla } \\
\text { camada com antracito. }\end{array}$ & $96 \mathrm{~m}^{2}$ & 280 a 420 \\
\hline$\checkmark \quad$ Decantador & 2 & $\begin{array}{l}\text { Fluxo ascendente com } \\
\text { Colméias. }\end{array}$ & $98 \mathrm{~m}^{2}$ & 280 a 375 \\
\hline$\checkmark \quad$ Floculador & 4 & Mecânico & $294 \mathrm{~m}^{3}$ & 230 a 450 \\
\hline \multicolumn{5}{|l|}{ ETA I (parte Nova) } \\
\hline$\checkmark \quad$ Filtro & 4 & $\begin{array}{l}\text { Filtro rápido de fluxo } \\
\text { descendente, dupla } \\
\text { camada com antracito }\end{array}$ & $74 \mathrm{~m}^{2}$ & 250 a 370 \\
\hline$\checkmark \quad$ Decantador & 4 & $\begin{array}{l}\text { Fluxo ascendente com } \\
\text { Colméias. }\end{array}$ & $288 \mathrm{~m}^{2}$ & 600 a 800 \\
\hline $\begin{array}{ll}\checkmark & \text { Floculador }\end{array}$ & 6 & Mecânico & $672 \mathrm{~m}^{3}$ & 370 a 750 \\
\hline
\end{tabular}

Fonte: UNIEMP, 2006. Organizado por Rodrigues, 2007. 
A água bruta do sistema ETA I é obtida pelo aproveitamento de quatro mananciais, são eles Ribeirão Pirapitingui, Ribeirão do Taquaral, Córrego Braiaiá e Córrego São José.

A Represa do Fubaleiro (Ribeirão Pirapitingui) construída em 1970 é mais antiga e também a de maior vazão $(330 \mathrm{l} / \mathrm{s})$, ela recebe água de uma pequena represa de acumulação no Ribeirão Pirapitingui localizada 200 metros acima dentro de um condomínio (Terras de S. José) e da represa do Taquaral localizada $1 \mathrm{~km}$ à montante da área de captação.

A água é aduzida pela gravidade por um tubo de concreto armado $(\$ 800 \mathrm{~mm}$; 0,6km) ao poço de sucção da Estação Elevatória de Água Bruta (EEAB) Fubaleiro, da qual é recalcada à ETA por uma adutora de ferro fundido $(\Phi 500 \mathrm{~mm} ; 1 \mathrm{Km})$. A represa do Taquaral é a mais recente construída no município e capta as águas do Ribeirão do Taquaral. A represa do Braiaiá tem vazão de $100 \mathrm{l} / \mathrm{s}$, e capta água de uma represa de acumulação no córrego Braiaiá, por canal de adução para poço de sucção da elevatória ao lado do vertedouro, de onde é direcionada para a ETA. A Represa dos Gomes é a de menor vazão (45 I/s) e recebe água de um conjunto de três represas de acumulação do Córrego Gomes situadas dentro de condomínio fechado (Campos de S. Antônio) (UNIEMP, 2006, p.30).

As EEAB's não são submersas e operam manualmente com comunicação por rádio com a ETA I. A freqüência de manutenção dos equipamentos é alta, especialmente na EEAB do Fubaleiro e do Braiaiá.

A EEAB do Gomes é a mais simples, e atualmente não necessita de reformas. A do Fubaleiro está em estado precário, perde energia por não ter a bomba direta na linha e suas instalações dificultam a manutenção. A EEAB do Braiaiá é ampla, mas a situação 
civil e elétrica é precária, além de não ter acesso, o que também dificulta a manutenção (UNIEMP, 2006, p.30-31).

Vários problemas são verificados nesta estação de tratamento como um todo, dentre eles podemos citar a falta de um centro de controle operacional, a necessidade da troca de equipamentos obsoletos por equipamentos mais avançados e a necessidade urgente de automação do sistema.

O sistema Inicial da ETA V data de 1908, porém a estação de tratamento foi construída só em 1992 (antes desta época a água vinha por gravidade e não era tratada sendo distribuída in natura). Apresenta baixa vazão (20 l/s) e abastece somente $5 \%$ da cidade. Os principais problemas verificados com esta ETA são as perdas físicas e o baixo número de dispositivos de descarga de ponta de rede, necessários para a limpeza da mesma.

A ETA VII Abastece cerca de $20 \%$ da área urbana principal e na verdade, é formada por um sistema composto por quatro pequenas ETA's compactas fechadas, com capacidade de $25 \mathrm{l} / \mathrm{s}$ cada, e uma ETA aberta, com capacidade de $15 \mathrm{l} / \mathrm{s}$ (DGA-UNESP, 1998, p.32). A estação está equipada com um bom laboratório e pessoal qualificado, porém uma parte da produção da ETA é desperdiçada com a lavagem dos filtros antigos. Esta prática gera uma perda de água da ordem de $10 \%$ que poderia ser evitada com a troca destes equipamentos por outros mais modernos (que exigem lavagem mais espaçada) ou minimizada com a implantação de um sistema de reuso da água proveniente da lavagem dos filtros.

A ETA III abastece o núcleo urbano secundário do bairro Pirapitingui e capta água do Córrego Varejão pouco antes da confluência com o Piragibú. Esta estação tem vazão de $30 \mathrm{l} / \mathrm{s}$ enquanto a ETA VIII, que também abastece o bairro Pirapitingui, aproveita a 
água do Córrego Varejão a montante da área urbana e tem vazão média de 60 l/s. Nestas duas ETA'S os problemas estão relacionados ao uso de equipamentos ultrapassados que facilitam as perdas de água tratada e a necessidade urgente de limpeza e reforma dos reservatórios.

\section{4 - Distribuição}

A maior parte das redes de distribuição de água do município de Itu encontra-se com problemas, sobretudo no que diz respeito às condições e o tempo de uso. A maior parte delas se encontra no núcleo urbano principal e é muito antiga, algumas com aproximadamente um século de existência como a usada para transportar a água captada do Córrego São José até a ETA V (Paraíso) que data de 1908. Porém, estima-se ainda que na área central existam redes mais antigas, uma vez que a primeira rede de distribuição de água construída pela prefeitura com canos de ferro data de 1890, como podemos verificar abaixo:

A câmara informa que em 7 de Janeiro de 1890 terminaram as obras do abastecimento público de água (...) Possuía a cidade de Ytu o seu abastecimento de água (...). (NARDY FILHO, 1999, vol.1, p.223).

Um detalhe que merece atenção refere-se às pressões na tubulação da área central, necessárias para levar a água de locais mais baixos até lá. Nesta região localizase a rede de distribuição mais antiga, o que certamente amplia o problema de perdas físicas. 
Infelizmente nem o SAAE e nem a prefeitura possuem informações detalhadas sobre a rede de água do município de Itu além das básicas, sobretudo no núcleo urbano principal (Figura 29). O levantamento atualizado das redes de distribuição de água por diâmetro e material é inexistente. Em 2008, de acordo com o SAAE, o total de redes atingiu a extensão de 554 km, porém inexistem informações referentes à extensão das redes de distribuição de água na sede e no distrito separadamente.

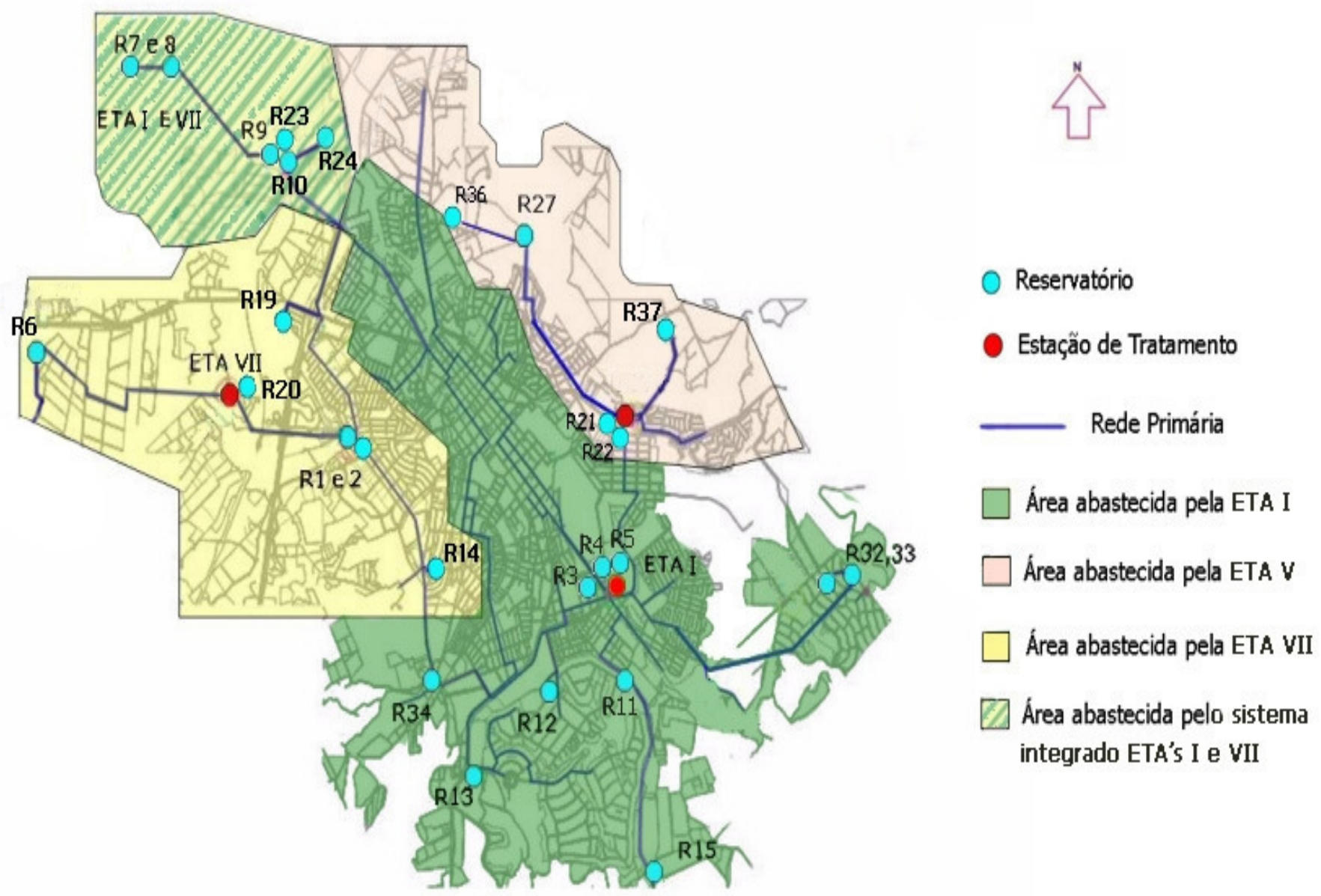

Figura 29 - Sistema de distribuição de água no núcleo urbano principal de Itu-SP. Fonte: SAAE, 2007. Adaptado e atualizado por Rodrigues, 2008. 
De acordo com a Endonucleum (2001), o projeto básico do núcleo do sistema de distribuição de água foi elaborado em 1972, e suas ampliações seguiram parcialmente o projeto original, respeitando as linhas primárias (troncos), com redes secundárias setorizadas. As informações de diâmetros de redes mostram uma quase inexistência de redes com $\varnothing 75 \mathrm{~mm}$, e uso demasiado de rede mínima com $\varnothing 50 \mathrm{~mm}$. Tal fato pode gerar problemas de perdas de carga excessiva em pontos extremos, o que cria problemas de abastecimento nas horas de maior consumo (UNIEMP, 2006, p.36).

Segundo o relatório da UNIEMP (2006) os principais problemas que a rede de distribuição de água do núcleo urbano principal enfrenta são:

- Alto índice de perdas físicas.

- Cadastro técnico desatualizado.

○ Redes antigas em condições precárias, altas pressões, com freqüentes vazamentos, especialmente as de cimento amianto.

- Falta de dispositivos de descarga de ponta de rede.

- Registros de manobra são desconhecidos e/ou insuficientes.

- Cavaletes não padronizados e sem abrigo, dificultado a hidrometração.

- Não há rede dupla nas ruas de grande movimento.

Ainda segundo o relatório, na área do núcleo urbano secundário (Figura 30) existem sérios problemas de distribuição no setor das ETA's III e VIII, sendo que os principais relacionam-se com à falta de capacidade de adução e deficiência de reservação.

Outros problemas detectados no sistema foram: 
- Possibilidade de médio índice de perdas físicas.

- Cadastro técnico existente, mas desatualizado.

- Falta de dispositivos de descarga de ponta de rede.

- Registros de manobra são desconhecidos e/ou insuficientes.

- Cavaletes não padronizados e sem abrigo, dificultado a hidrometração.

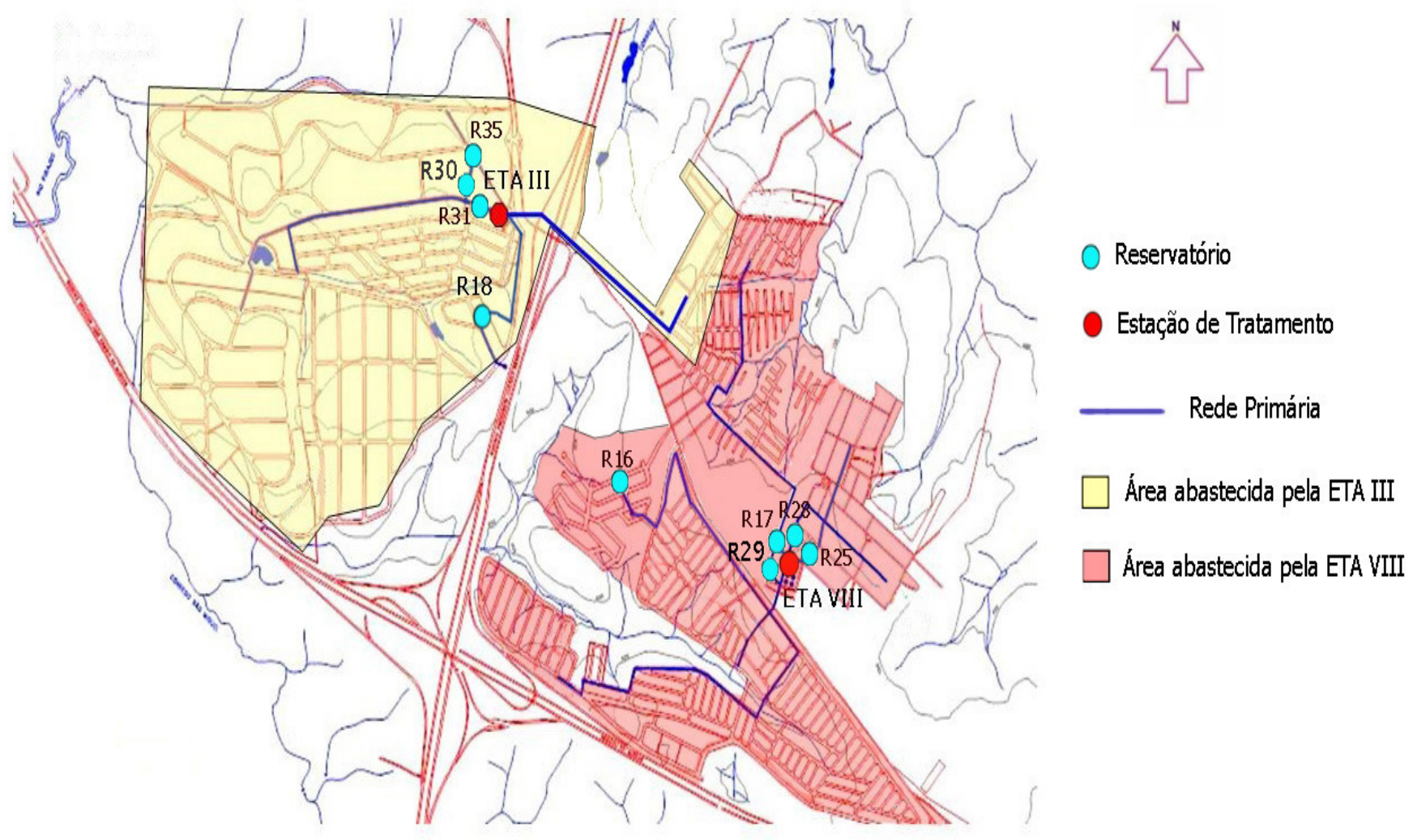

Figura 30 - Sistema de distribuição de água no núcleo urbano secundário do Pirapitingui. Fonte: SAAE, 2007. Adaptado e atualizado por Rodrigues, 2008. 


\section{0 - Resultados e Discussões}

10.1 - Os reflexos socioeconômicos da escassez de água no município de Itu-SP

Neste capítulo abordaremos os resultados obtidos no tratamento e análise das informações referentes aos reflexos do problema da escassez de água para abastecimento público em Itu-SP. Primeiramente tentamos encontrar relações entre a problemática em foco e a economia ituana, e depois, adotando o mesmo procedimento, buscamos correlacionar a escassez de água com alguns problemas sociais que ocorrem no município.

10.1.1 - Reflexos da falta de água para abastecimento público na economia Ituana (Indústria e comércio)

A primeira indústria instalada na cidade foi a tecelagem São Luís em 1869. Fundada por empresários ituanos que viam na indústria têxtil um grande negócio, ela se desenvolveu bem no início, em grande parte pela facilidade ao acesso de mão-de-obra e matéria prima, já que neste período o cultivo de algodão era uma das atividades agrícolas praticadas no município. Apesar das dificuldades tecnológicas da época a fábrica continuou a crescer sendo a primeira indústria de tecidos a utilizar máquinas a vapor no estado de São Paulo. 
A primeira fábrica de tecidos, movida a vapor, que se fundou em São Paulo foi a fábrica São Luiz, da cidade de Itu e da qual foi o principal fundador e organizador o Coronel Luiz Antônio de Anhaia. (NARDY FILHO, 1999, vol.6, p.195).

Esta fábrica possuía maquinário moderno e tinha alta produtividade, era um exemplo de empreendimento pioneiro e que logo após o início do seu funcionamento já apresentava excelentes resultados. A 19 de Janeiro de 1870 passou por Itu, o presidente da província, Dr. Antônio Candido da Rocha, que na ocasião veio tratar da organização da Companhia Ituana de Estrada de Ferro, e fez o seguinte pronunciamento sobre ela:

A fábrica São Luiz foi por mim visitada e confesso-vos que possui-me de prazer quando a vi funccionar. O seu bello e complicado machinismo funcciona com perfeita precisão e presteza. (...) Assim seu tão patriótico exemplo desperte a concepção de novas emprezas industriaes, que venhão dar applicação ás materias primas, que com tanta profusão produz a Província. (NARDY FILHO, 1999, vol.6, p.212).

Em visita à cidade em 21 de Dezembro de 1872 assim se expressou o conselheiro do governo imperial Pinto e Lima:

Já a indústria fabril não é considerada como uma utopia ou como loucura, sendo pelo contrário encarada como uma fonte de riqueza e bem estar; hoje acha-se perfeitamente montada na cidade de Itu a 
importantíssima fábrica São Luís (...) cujos resultados tem excedido à expectativa de seus proprietários. (NARDY FILHO, 1999, vol.6, p.215).

Vale ressaltar que por ser uma tecelagem este tipo de indústria não necessita de grandes quantidades de água para o seu funcionamento, deste modo a tecelagem São Luís não foi muito afetada por problemas relacionados à falta deste recurso.

Com o passar dos anos a indústria têxtil deixou de ser o principal ramo de atividade industrial do município sendo substituído pelo siderúrgico com a implantação de pequenas fundições por volta dos anos 40, com destaque para a fundição Gazzola fundada em 1944. Já no caso das fundições o uso da água se dá em maior quantidade e as indústrias da época já sentiam na prática as dificuldades que iam enfrentar para terem a sua disposição este recurso.

Em meados de 1970 um outro tipo de indústria começa a se desenvolver no município, a alimentícia, que atualmente é o setor de maior desenvolvimento industrial de Itu e emprega boa parte da mão-de-obra existente na região. À partir deste período serão verificados os problemas mais graves no que diz respeito à falta de água para abastecimento público em Itu.

Como já dito, a população total cresceu demasiadamente do meio para o final do século XX, ela mais que triplicou em 37 anos (1970-2007) (Tabela 1). Acompanhando o crescimento total houve também um crescimento significativo da população urbana, o que gerou um aumento considerável na demanda de água residencial. Ocorreu também um grande aumento da demanda nos setores da economia. No primário com o incentivo da prefeitura às atividades agropecuárias, no terciário com o desenvolvimento do comércio e, 
principalmente no secundário, o que exigiu grandes ofertas de água para seu desenvolvimento.

Atualmente as duas principais indústrias de alimentos do município são a Schincariol (indústria de bebidas) e a Elma Chips (Indústria de salgadinhos)³. A Schincariol foi fundada em 1939 e durante muitas décadas produziu apenas refrigerantes, porém em 1989 fundou a cervejaria e passou de uma pequena empresa local a mais importante indústria do município possuindo atualmente (2008) um quadro de 3.500 funcionários. A Elma Chips é parte da pepsico uma multinacional norte-americana que fabrica produtos alimentícios e está em Itu desde 1983 produzindo salgadinhos. Atualmente (2008) conta com um efetivo de 1.100 funcionários e é a segunda maior indústria do município em importância. Essas duas empresas com grande potencial produtivo já sofreram grandes perdas com os problemas relacionados ao abastecimento público de água, visto a importância do recurso para a indústria alimentícia.

A Schincariol tentou de diversas formas fazer acordos com o poder público no intuito de minimizar os impactos causados pelos grandes racionamentos e continuar tendo água à sua disposição. Segundo o engenheiro Hamilton Guido (comunicação pessoal, 2006) a empresa resolveu agir quando viu que a prefeitura não teria condições de oferecer água nas épocas críticas, sendo assim, a empresa acabou por idealizar a seguinte meta: "Ser independente do poder público no que diz respeito ao abastecimento de água".

A direção da empresa afirma, que se continuasse dependente da prefeitura no que diz respeito a oferta de água certamente teria problemas como a diminuição da produção

${ }^{3}$ A citação de marcas comerciais não expressa, por parte do autor, indicação de consumo. 
uma vez que a água é matéria prima insubstituível na produção de bebidas. Passou-se então a investir consideravelmente na captação deste recurso, furou poços artesianos e construiu barragens em suas terras o que com o tempo fez com a empresa ficar cada vez menos dependente da água oferecida pelo município, atingindo assim as metas preestabelecidas. Atualmente a Schincariol em nada depende neste setor, além disso, doa água para hospitais e escolas nos períodos de racionamento crônico assim como faz também a Elma Chips. Em 2000, o ano mais crítico na cidade, a empresa chegou a fazer doações de água para o próprio SAAE para abastecimento de bairros carentes.

Uma técnica utilizada na fábrica é o reuso da água no intuito de cumprir as leis ambientais e diminuir os gastos além do tratamento de efluentes, que segundo a avaliação da CETESB, chega a 99,5\% de eficiência. O engenheiro salienta que a indústria sempre teve interesse em adquirir água do SAAE caso este tivesse em condições de oferecê-la em grandes quantidades e de maneira incondicional em qualquer época do ano. Contudo, como o poder público não consegue cumprir estas exigências a empresa prefere gastar mais com infra-estrutura neste setor e evitar problemas futuros com a falta do recurso em épocas calamitosas.

Esse é um caso típico de perda de arrecadação para o SAAE já que se trata de uma grande demanda. Como a disponibilidade do recurso é pequena e instável, a empresa adquire o recurso por meios próprios e não através da compra de água do serviço público, o que diminui a arrecadação da autarquia.

Outra indústria que enfrentou problemas nas últimas décadas foi a Elma Chips. Segundo Marcos Ricieri (Comunicação pessoal, 2006) um dos engenheiros responsáveis pelo funcionamento da empresa em Itu, são gastos $50 \mathrm{~m}^{3}$ hora de água na lavagem da batata, lavagem e cozimento do milho, que são as matérias primas dos salgadinhos. No 
final da década de 90 o município iniciava a pior fase no que diz respeito à oferta de água uma vez que a estiagem durou bem mais do que se esperava. Nesta época a empresa foi obrigada a diminuir a produção em algumas horas (deixando 500 funcionários parados), pois a prefeitura limitou a quantidade de água que era oferecida às indústrias.

Marcos ressaltou que em 2000 (pior ano enfrentado pela cidade no que diz respeito à falta de água) ocorreu uma falha da prefeitura em não notificar a empresa sobre a indisponibilidade de água, dando início repentinamente a um grande racionamento o que os levou a buscar alternativas imediatas sem nenhum planejamento prévio. Neste período a indústria foi obrigada a recorrer a alternativas urgentes para não ter a paralisação total de sua produção, como a compra de água de particulares. Para tanto pagou um valor de 10 a $12 \%$ mais caro do que pagava à prefeitura diminuindo significativamente seus lucros. A empresa afirmou que foram gastos US $\$ 223.255,00$ (reais de 2000) a mais com a compra de água de particulares, além de gerar alguns outros danos para o município tais como o aumento significativo do fluxo de caminhões pipa (o que causa congestionamentos e destruição do asfalto nas ruas da cidade) e a diminuição de arrecadação do SAAE neste período. A situação chegou a um nível tão ruim que em 2002 cogitou-se a hipótese da fábrica transferir-se para a cidade de Sorocaba por causa dos problemas relacionados à falta de água, porém a idéia foi abandonada uma vez os custos desta transferência seriam muito elevados.

Após o ocorrido fez-se um contrato para comprar água de empresas privadas para não ficar a mercê das variações climáticas, apontadas pela prefeitura como causadoras da diminuição da oferta de água, hipótese esta, cientificamente rechaçada. Este tipo de empresa cresceu significativamente nas últimas décadas, uma vez que empresários locais vêem neste setor a oportunidade de ganhar grandes quantias de dinheiro. A Elma 
Chips paga $10 \%$ mais barato por metro cúbico de água do que pagaria à prefeitura, isso ocorre devido a acordos realizados e a concorrência gerada por este aumento do mercado paralelo da venda de água no município. O órgão mais atingido por esta prática é o próprio SAAE, que diminuiu muito sua arrecadação já que a cada ano mais indústrias recorrem às empresas privadas que comercializam água, sobretudo por possuírem boa infra-estrutura para atendê-las nos piores momentos e ainda a um custo menor do que o valor cobrado pela autarquia por metro cúbico de água.

Atualmente (2008) o SAAE cobra 5 reais por $\mathrm{m}^{3}$ de água para indústrias enquanto no mercado paralelo o preço é de aproximadamente 6 reais por $\mathrm{m}^{3}$. Todavia quando adquirido em maiores quantidades o preço geralmente fica abaixo desse valor. Além disso, existe uma segurança maior em comprar de particulares pois, nem sempre o SAAE tem água disponível enquanto a oferta e a eficiência do serviço particular é indiscutivelmente superior.

A situação é tão complexa que as próprias empresas, inclusive a Elma Chips, compram água de particulares pra doar para escolas e hospitais do município em épocas de estiagem. Isso nos mostra a insuficiência preocupante do setor de abastecimento de água na cidade.

Leonel Salvador ex-prefeito de Itu reconheceu que em seu mandato (1996 - 2000) enfrentou sérios problemas que segundo ele, foram conseqüência de erros das administrações passadas. "Sempre faltou uma política de planejamento, infra-estrutura e saneamento para o município" afirmou.

A cidade tem excelente localização, boa rede de transporte, proximidade com fontes de matérias prima, energia e comunicação, porém a falta de planejamento e investimentos públicos "espantam" os investidores que preferem instalar seus 
empreendimentos em municípios vizinhos. O ex-prefeito citou que Itu sofre um processo de desindustrialização causado principalmente pelo relacionamento ruim entre empresários e poder público. Além disso o problema da falta de água tornou-se conhecido nacionalmente em 2000 com a exibição de reportagens relacionadas a esta temática no programa jornalístico Fantástico da Rede Globo de televisão. Ele referiu ainda que recentemente duas empresas não se instalaram em Itu por acreditarem que seriam afetadas pelo problema da falta de água, são elas a Sucos del Valle e a Alcatell uma empresa de fios e cabos elétricos. Ambas procuraram se instalar em cidades vizinhas com situação político-administrativa melhor e com serviço de abastecimento de água eficiente.

Apesar da arrecadação diminuir ano a ano para ele o maior problema do SAAE não é de ordem econômica mas sim política. "Políticos utilizam a autarquia em benefício próprio, utilizam-se do problema da falta de água em anos eleitorais para se elegerem e depois nada é feito para consertar a situação. O SAAE tem que ser independente, sem relações políticas com a prefeitura municipal”, ressaltou Leonel.

O ex-prefeito coloca ainda que na sua visão o problema chegou a uma dimensão tão grande que não há perspectivas para Itu se o problema em questão não for solucionado. Vale lembrar que Leonel sempre foi um defensor assíduo da concessão da autarquia inclusive no seu governo quando tentou sem sucesso fazê-la. Para ele, esta é a única solução em curto prazo para o problema do abastecimento público de água em Itu.

Um assunto intrigante que foi comentado por Leonel, é a questão da saída de indústrias ou a preferência por cidades vizinhas onde a situação seja mais favorável, e como morador da cidade, sempre ouvi rumores de que isso realmente acontecia. Os motivos pelos quais uma indústria deixa um município ou não se instala nele podem ser 
diversos, mas sem dúvida a questão da oferta de água tem um grande peso. A água é um elemento básico e imprescindível para o funcionamento de qualquer indústria, sem ela as condições para a instalação ou permanência de uma indústria seriam desfavoráveis. Além disso, é fato que Itu, infelizmente, já possui uma imagem negativa no que diz respeito ao abastecimento público de água como disse o ex-prefeito Leonel Salvador.

Partindo da idéia de que seria muito importante analisar também este aspecto, realizamos um levantamento sobre a história recente das indústrias de Itu e região (cidades próximas). Os objetivos eram obter dados importantes sobre a evolução do número de indústrias, a participação de cada município no total geral da região e o crescimento das atividades industriais em cada um deles. Estes levantamentos nos permitiriam compreender a dinâmica das atividades industriais e saber se o problema da falta de água interfere ou não na industrialização de Itu.

Os primeiros dados a serem mostrados são referentes ao número de estabelecimentos industriais nas cidades de Itu, Sorocaba, Salto Indaiatuba e Cabreúva entre os anos de 1991 e 2005. A escolha destes municípios se deve ao fato de fazerem limite com Itu e por possuírem características gerais semelhantes (sobretudo Salto e Indaiatuba). Sorocaba é o grande centro regional e Cabreúva é o menor deles.

Os dados da tabela abaixo (Tabela 2), mostram o número bruto de estabelecimentos industriais, o valor total regional, e o crescimento em porcentagem do número de indústrias nos referidos municípios ao longo de 15 anos.

Pelas informações podemos perceber que o município de Itu foi o que menos cresceu em números de estabelecimentos industriais comparativamente a outros municípios vizinhos. 
Tabela 2 - Evolução do número bruto, total geral e crescimento em \% do número de estabelecimentos Industriais de Itu, Sorocaba, Salto, Indaiatuba e Cabreúva entre $1991-2005$

\begin{tabular}{|c|c|c|c|c|c|c|}
\hline & \multicolumn{5}{|c|}{ Número de Estabelecimentos Industriais } & \\
\hline Ano & Itu & Sorocaba & Salto & Indaiatuba & Cabreúva & Total \\
\hline 1991 & 329 & 808 & 153 & 291 & 66 & 1647 \\
\hline 1992 & 315 & 791 & 146 & 297 & 75 & 1624 \\
\hline 1993 & 299 & 774 & 152 & 290 & 63 & 1578 \\
\hline 1994 & 373 & 755 & 153 & 310 & 82 & 1673 \\
\hline 1995 & 393 & 821 & 192 & 401 & 89 & 1896 \\
\hline 1996 & 398 & 876 & 178 & 424 & 86 & 1962 \\
\hline 1997 & 382 & 906 & 181 & 491 & 86 & 2046 \\
\hline 1998 & 382 & 893 & 182 & 485 & 94 & 2036 \\
\hline 1999 & 386 & 906 & 189 & 484 & 90 & 2055 \\
\hline 2000 & 402 & 946 & 191 & 509 & 100 & 2148 \\
\hline 2001 & 412 & 1048 & 194 & 544 & 113 & 2311 \\
\hline 2002 & 417 & 1057 & 207 & 573 & 120 & 2374 \\
\hline 2003 & 435 & 1078 & 230 & 578 & 131 & 2452 \\
\hline 2004 & 442 & 1117 & 235 & 611 & 129 & 2534 \\
\hline 2005 & 456 & 1205 & 255 & 648 & 137 & 2701 \\
\hline Crescimento $(\%)$ & $39 \%$ & $49 \%$ & $67 \%$ & $123 \%$ & $100 \%$ & \\
\hline
\end{tabular}

Fonte: Fonte: www.seade.gov.br, acesso em Janeiro de 2008. Organizado por Rodrigues, 2008.

Enquanto Itu cresceu apenas 39\% neste período, municípios como Salto (67\%), Cabreúva (108\%) e Indaiatuba (123\%) tiveram um incremento maior no número de Indústrias e consequentemente na economia. O gráfico a seguir (Figura 31) mostra melhor estas informações. 


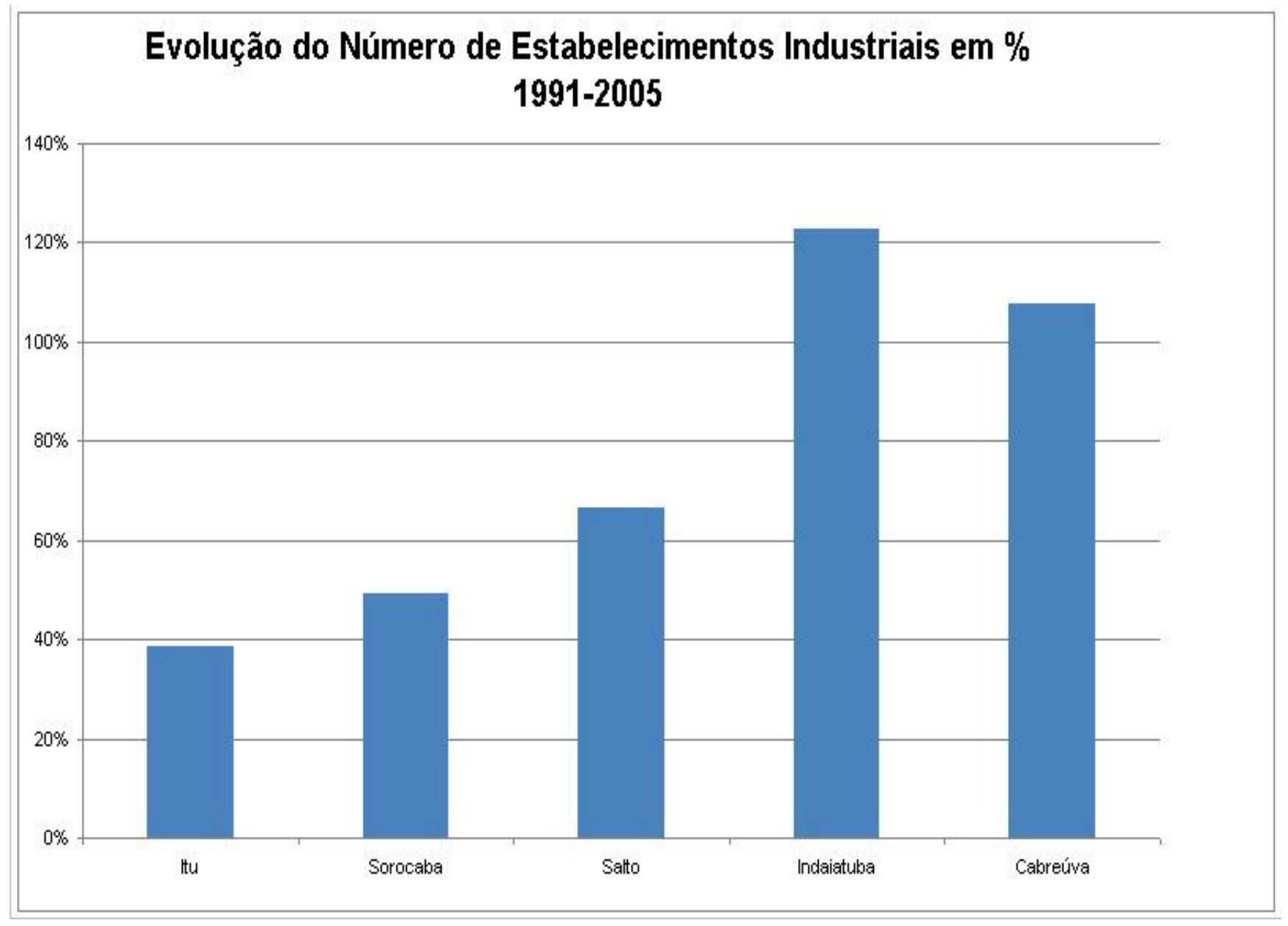

Figura 31 - Evolução do número de estabelecimentos industriais em \% em Itu, Sorocaba, Salto, Indaiatuba e Cabreúva entre 1991 - 2005.

Fonte: SEADE, 2008. Organizado por Rodrigues, 2008.

Podemos ainda mostrar estes dados num gráfico de evolução relativa (base 100), o que nos dá uma melhor visão dos fatos (Figura 32). 


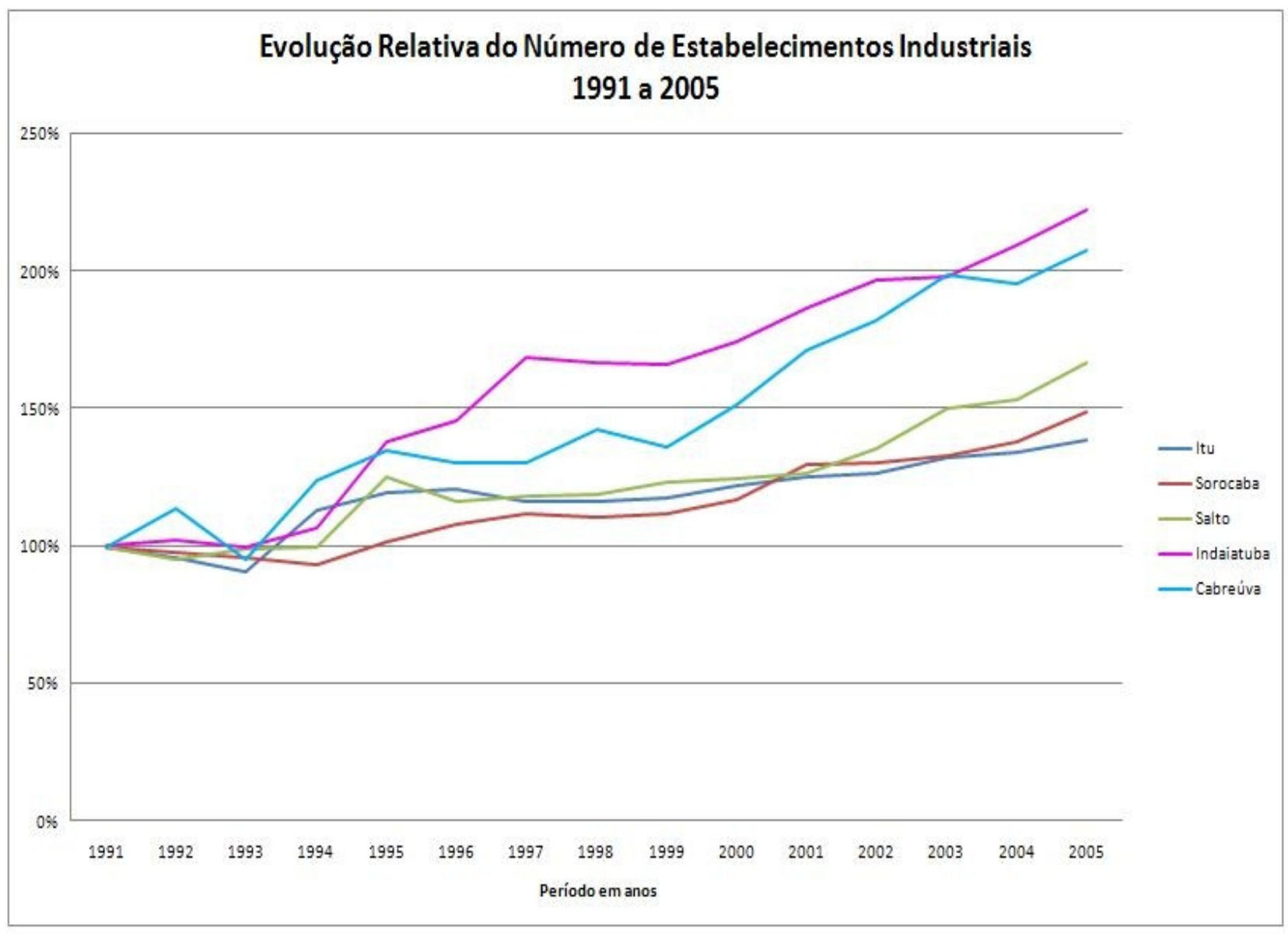

Figura 32 - Evolução relativa do número de estabelecimentos industriais em Itu, Sorocaba, Salto, Indaiatuba e Cabreúva entre 1991 - 2005.

Fonte: SEADE, 2008. Organizado por Rodrigues, 2008.

Considerando a participação que estes municípios possuem no número de estabelecimentos industriais nos tempos atuais (2005) em relação 1991, podemos ver que Itu foi o que mais perdeu importância no cenário regional (Tabela 3). 
Tabela 3 - Evolução em \% da participação dos municípios de Itu, Sorocaba, Salto, Indaiatuba e Cabreúva no número de estabelecimentos Industriais entre 1991 - 2005.

\begin{tabular}{|c|c|c|c|c|c|}
\hline & \multicolumn{5}{|c|}{ Participaçäo do Municipio no Número de Estabelecimentos Industriais na Regiäo Avaliada } \\
\hline Ano & Itu & Sorocaba & Salto & Indaiatuba & Cabreúva \\
\hline 1991 & $20 \%$ & $49 \%$ & $9 \%$ & $18 \%$ & $4 \%$ \\
\hline 1992 & $19 \%$ & $49 \%$ & $9 \%$ & $18 \%$ & $5 \%$ \\
\hline 1993 & $19 \%$ & $49 \%$ & $10 \%$ & $18 \%$ & $4 \%$ \\
\hline 1994 & $22 \%$ & $45 \%$ & $9 \%$ & $19 \%$ & $5 \%$ \\
\hline 1995 & $21 \%$ & $43 \%$ & $10 \%$ & $21 \%$ & $5 \%$ \\
\hline 1996 & $20 \%$ & $45 \%$ & $9 \%$ & $22 \%$ & $4 \%$ \\
\hline 1997 & $19 \%$ & $44 \%$ & $9 \%$ & $24 \%$ & $4 \%$ \\
\hline 1998 & $19 \%$ & $44 \%$ & $9 \%$ & $24 \%$ & $5 \%$ \\
\hline 1999 & $19 \%$ & $44 \%$ & $9 \%$ & $24 \%$ & $4 \%$ \\
\hline 2000 & $19 \%$ & $44 \%$ & $9 \%$ & $24 \%$ & $5 \%$ \\
\hline 2001 & $18 \%$ & $45 \%$ & $8 \%$ & $24 \%$ & $5 \%$ \\
\hline 2002 & $18 \%$ & $45 \%$ & $9 \%$ & $24 \%$ & $5 \%$ \\
\hline 2003 & $18 \%$ & $44 \%$ & $9 \%$ & $24 \%$ & $5 \%$ \\
\hline 2004 & $17 \%$ & $44 \%$ & $9 \%$ & $24 \%$ & $5 \%$ \\
\hline 2005 & $17 \%$ & $45 \%$ & $9 \%$ & $24 \%$ & $5 \%$ \\
\hline Crescimento (\%) & $-15 \%$ & $-9 \%$ & $2 \%$ & $36 \%$ & $27 \%$ \\
\hline
\end{tabular}

Fonte: Fonte: www.seade.gov.br, acesso em Janeiro de 2008. Organizado por Rodrigues, 2008.

A ilustração dessas informações num gráfico de colunas também pode ser feita, permitindo-nos uma melhor visualização das informações citadas acima (Figura 33). 


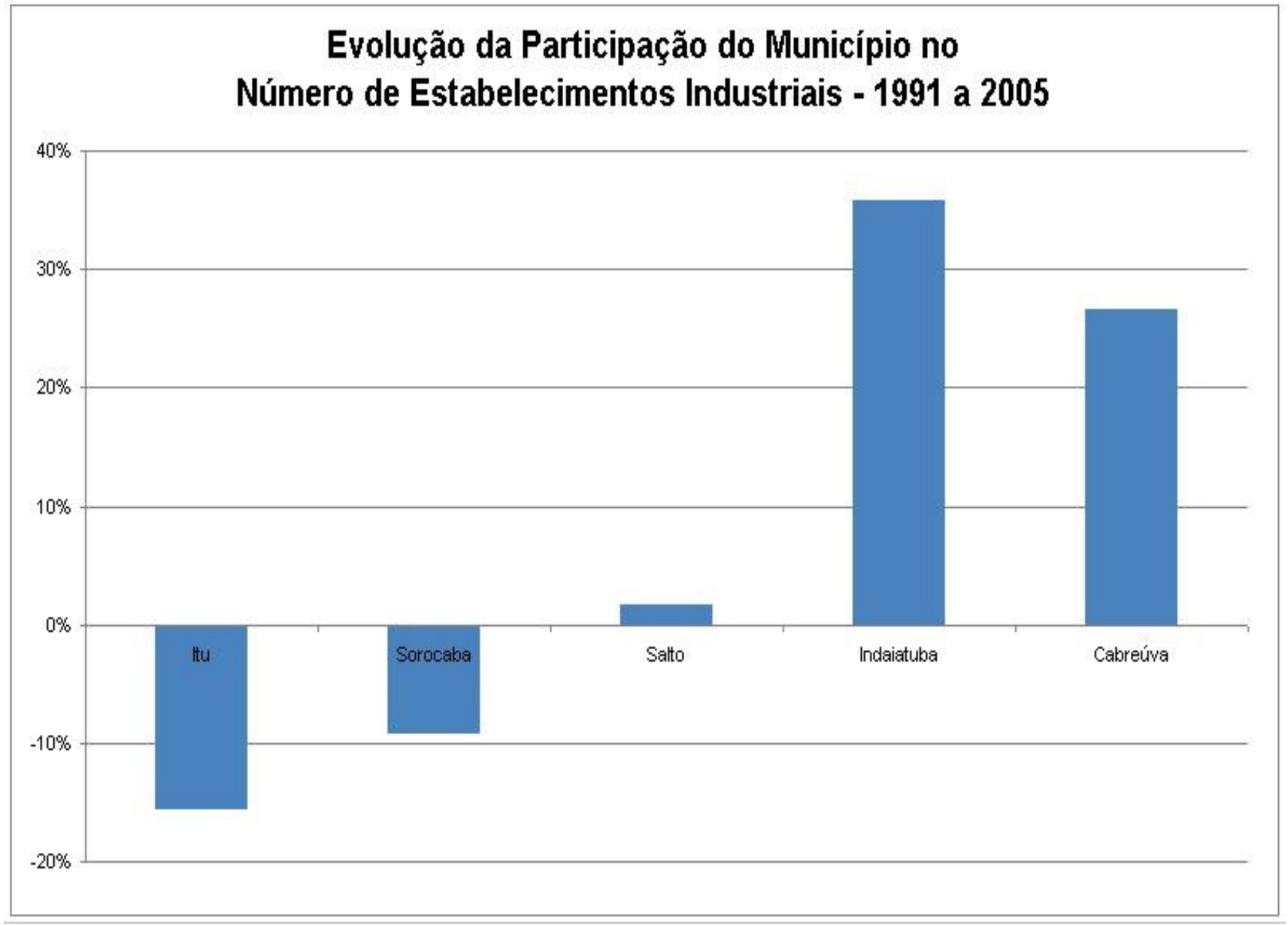

Figura 33 - Evolução da participação dos municípios de Itu, Sorocaba, Salto, Indaiatuba e Cabreúva no número de estabelecimentos industriais em \% entre 1991 - 2005.

Fonte: SEADE, 2008. Organizado por Rodrigues, 2008.

O gráfico abaixo (Figura 34) nos mostra informações referentes à participação relativa (base 100) dos municípios no número de estabelecimentos industriais entre o período de 1991 - 2005. Através dele podemos perceber que a linha que representa Itu está numa queda quase contínua após o ano de 1994 até 2005. Vale ressaltar que no ano de 2000 existe uma queda ainda maior na participação de Itu no número de 
estabelecimentos industriais da região, em contrapartida houve um incremento na participação da maioria dos municípios vizinhos .

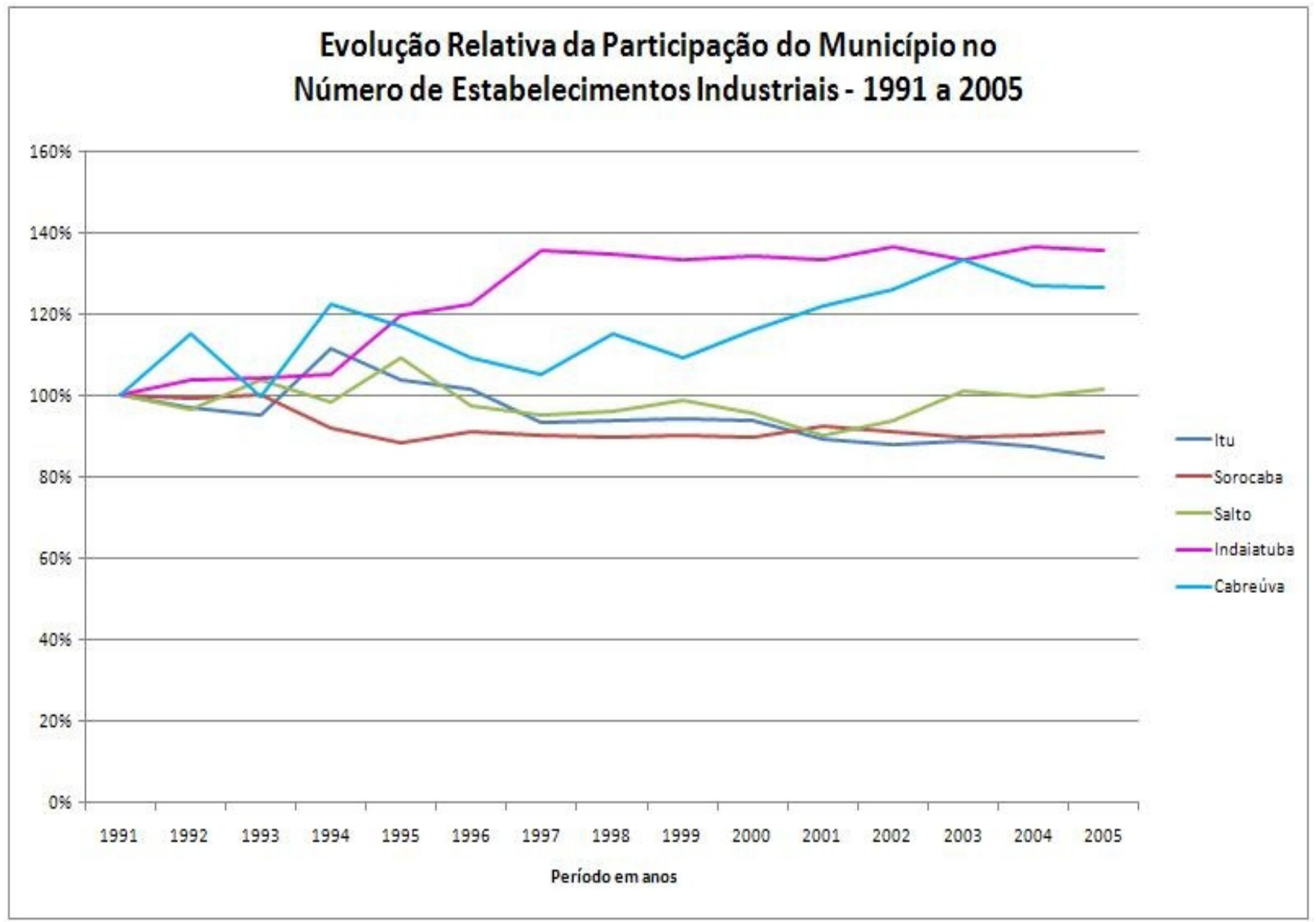

Figura 34 - Evolução relativa da participação dos municípios de Itu, Sorocaba, Salto, Indaiatuba e Cabreúva no número de estabelecimentos industriais entre 1991 - 2005.

Fonte: SEADE, 2008. Organizado por Rodrigues, 2008.

O delegado do CRECI (Conselho Regional dos Corretores de Imóveis) de Itu Sr Newton Loyola, que trabalha à quase 30 anos no setor de compra e venda de imóveis no 
município, afirmou que a falta de água para abastecimento público causou ao longo das últimas décadas prejuízos para os corretores de imóveis ituanos. Segundo ele muitos empresários que pretendem abrir algum negócio em Itu optam por cidades vizinhas quando tem conhecimento do problema da falta de água. O mercado imobiliário tem visto propagandas negativas do município nesta questão, por estes e outros motivos apontados adiante Itu apresenta um inexpressivo crescimento deste ramo da sua economia.

Ele destaca que em Itu o problema é de incapacidade administrativa, pois o município tem como obter recursos econômicos, além de ter excelente situação geográfica e estar localizado próximo às grandes centros urbanos e importantes rodovias. Mesmo assim os investidores preferem ir para municípios próximos como Sorocaba, Jundiaí, Indaiatuba, Salto, Porto Feliz e Cabreúva por terem menos problemas burocráticos e maior oferta de água nestas localidades.

Segundo o Delegado do CRECI de Itu "As cidades vizinhas cresceram demasiadamente, pois a incapacidade administrativa de Itu fez com que muitos empresários deixassem de se instalar aqui e procurassem estas localidades. Isso ocasionou um expressivo desenvolvimento destes núcleos urbanos em vários setores e conseqüente melhoria nas condições de vida da população local, enquanto nós permanecemos estagnados sem apresentar crescimento significativo em nenhum setor há muito tempo." Newton demonstrou preocupação com o crescimento do número de condomínios em Itu já que a maior parte deles tem captação de água subsuperficial através de poços artesianos ou ainda compram água de particulares, o que estimula cada vez mais o aparecimento deste tipo de empresa no município. Na sua opinião a responsabilidade é do próprio SAAE que demora até noventa dias para fazer uma instalação de água em um estabelecimento comercial ou industrial, prejudica o novo 
empresário e contribui para que a má fama do município persista. "Algo tem que ser feito para que esta autarquia funcione de maneira eficiente, caso contrário a situação tende a piorar cada vez mais. O SAAE está falindo, sem grandes arrecadações e conseqüentemente sem capital para novos investimentos no setor" comentou.

Sabíamos que o problema existia, mas ao entrar em contato com dados técnicos e pessoas que nos passaram valiosas informações, pudemos perceber que a gravidade da situação é ainda maior do que a anteriormente imaginada.

Estas informações se referem, sobretudo, à atual situação do SAAE em relação à demanda de água residencial, comercial e industrial e aos reflexos econômicos do problema em foco principalmente na última década (atenção especial para os anos de 1999, 2000 e 2001). É importante ressaltar que a escolha deste período para análise foi em função de ter sido até hoje o mais crítico enfrentado pelo município em relação à falta de água para abastecimento público. Os dados e resultados estão na forma de gráficos, o que possibilita uma visão real e detalhada dos fatos.

Os primeiros gráficos que iremos mostrar tratam do consumo de água entre os anos de 1997 e 2006 nos setores mencionados anteriormente. Nota-se que no setor residencial ocorreram oscilações consideradas normais por se tratarem de domicílios, mesmo assim a maior demanda ocorreu no ano de 1998 antes do período mais crítico, entre 1999 e 2001 (Figura 35). 


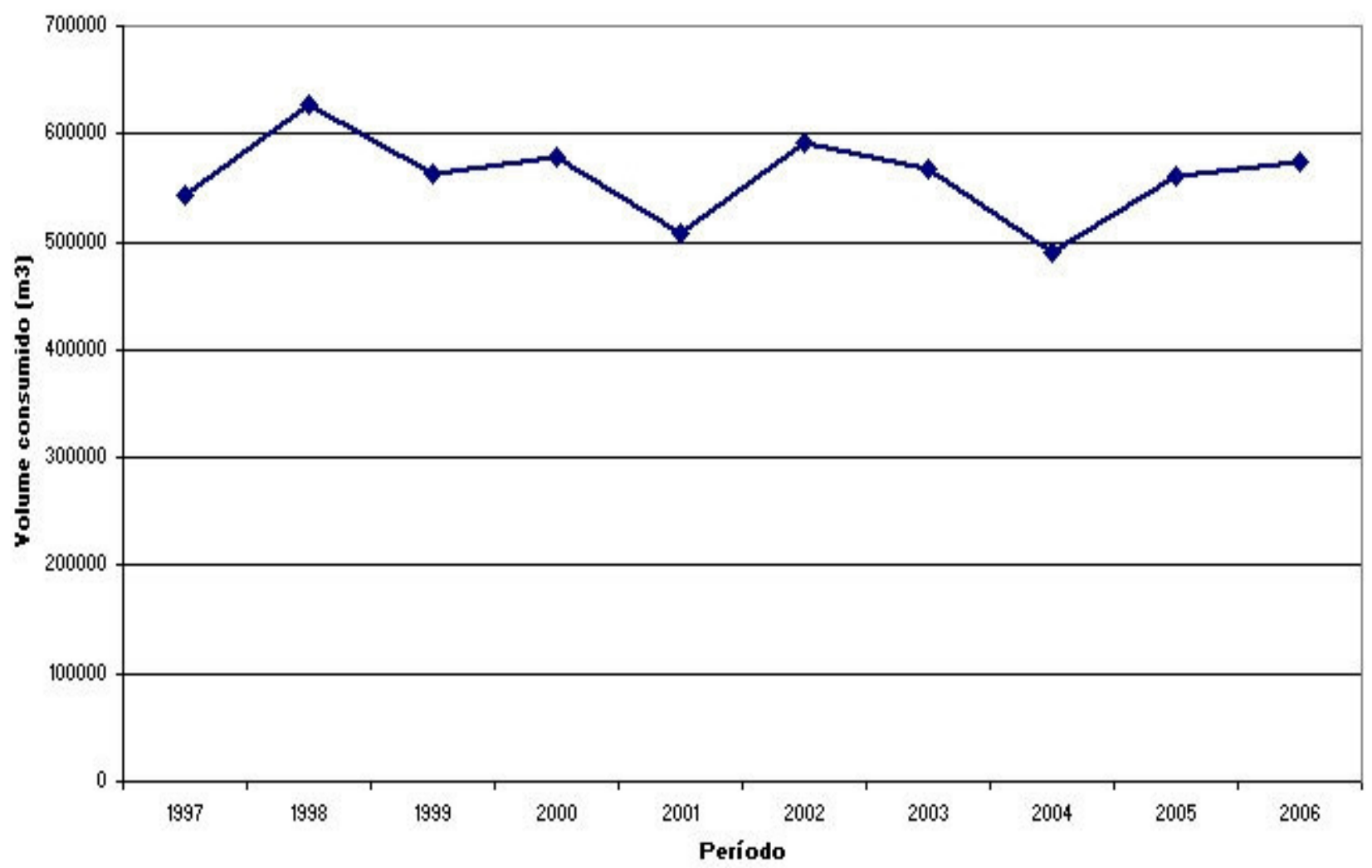

Figura 35 - Volume consumido pela categoria residencial entre os anos de 1997 e 2006. Fonte: SAAE, 2007. Organizado por Rodrigues, 2007.

No setor comercial (Figura 36), nota-se uma queda no consumo a começar em 1998 e terminar em 2001 quando volta a elevar-se. Esta queda certamente está relacionada ao problema crônico vivido pelo município no período em questão. Certamente os prejuízos causados ao comércio local por este problema não foram poucos. 


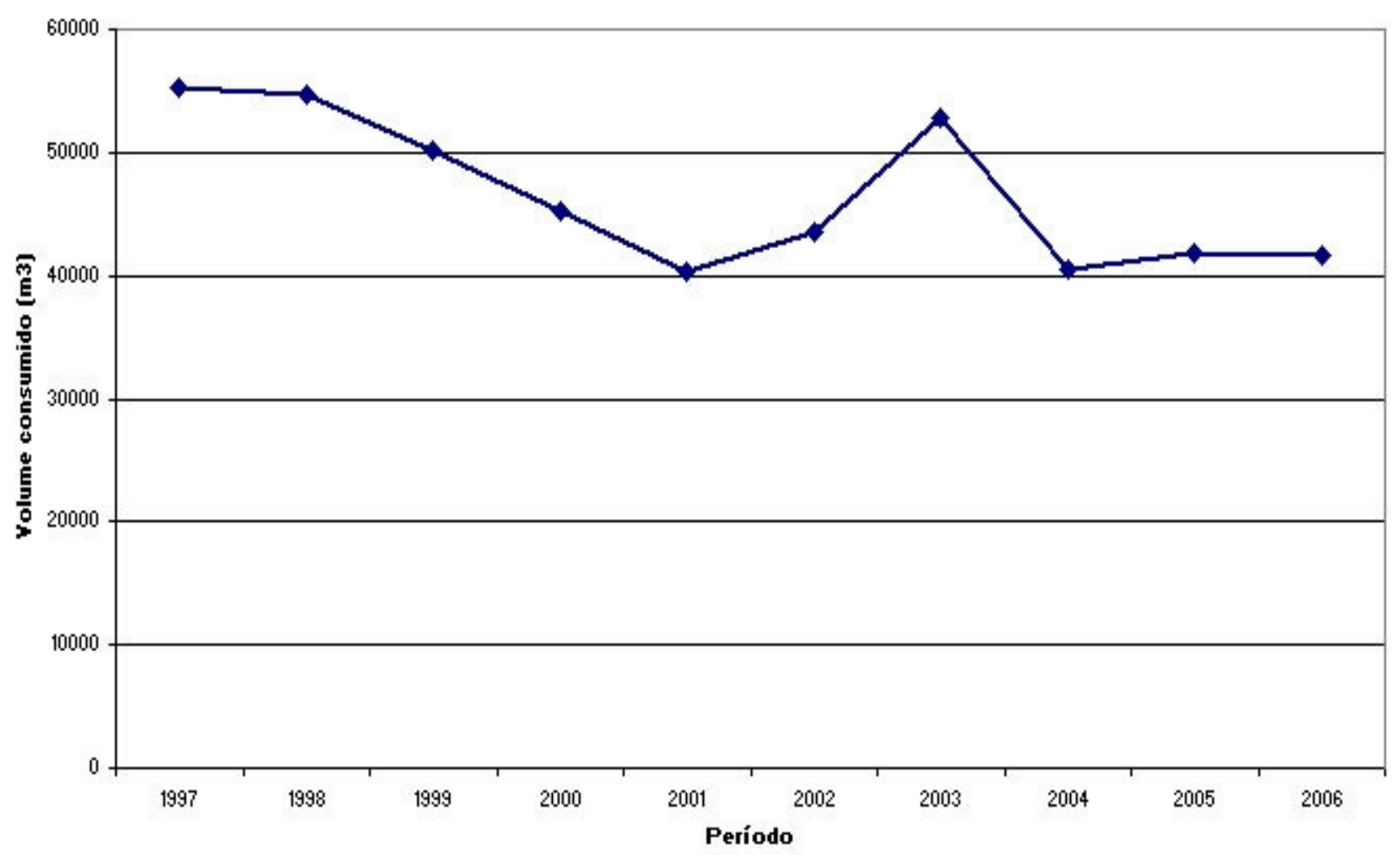

Figura 36 - Volume consumido pela categoria comercial entre os anos de 1997 e 2006. Fonte: SAAE, 2007. Organizado por Rodrigues, 2007.

Porém foi no ramo industrial (principal gerador de emprego e impostos) que a queda no consumo foi maior, ela se iniciou já em 1997 e foi até 2001 (Figura 37). Pelos dados e entrevistas que foram feitas estes dados sugerem uma possível "fuga de capital" com a mudança destas empresas para cidades próximas e uma diminuição no consumo da água fornecida pelo SAAE. Muitas empresas já há algum tempo estão preferindo comprar água de particulares uma vez que esta água, apesar de um pouco mais cara, é 
garantida e fornecida de forma contínua o que não atrapalha a produção. Já o SAAE apesar de fornecer água mais barata tem uma produção instável e constantemente ameaçada pelos racionamentos, o que prejudica muito as empresas instaladas no município.

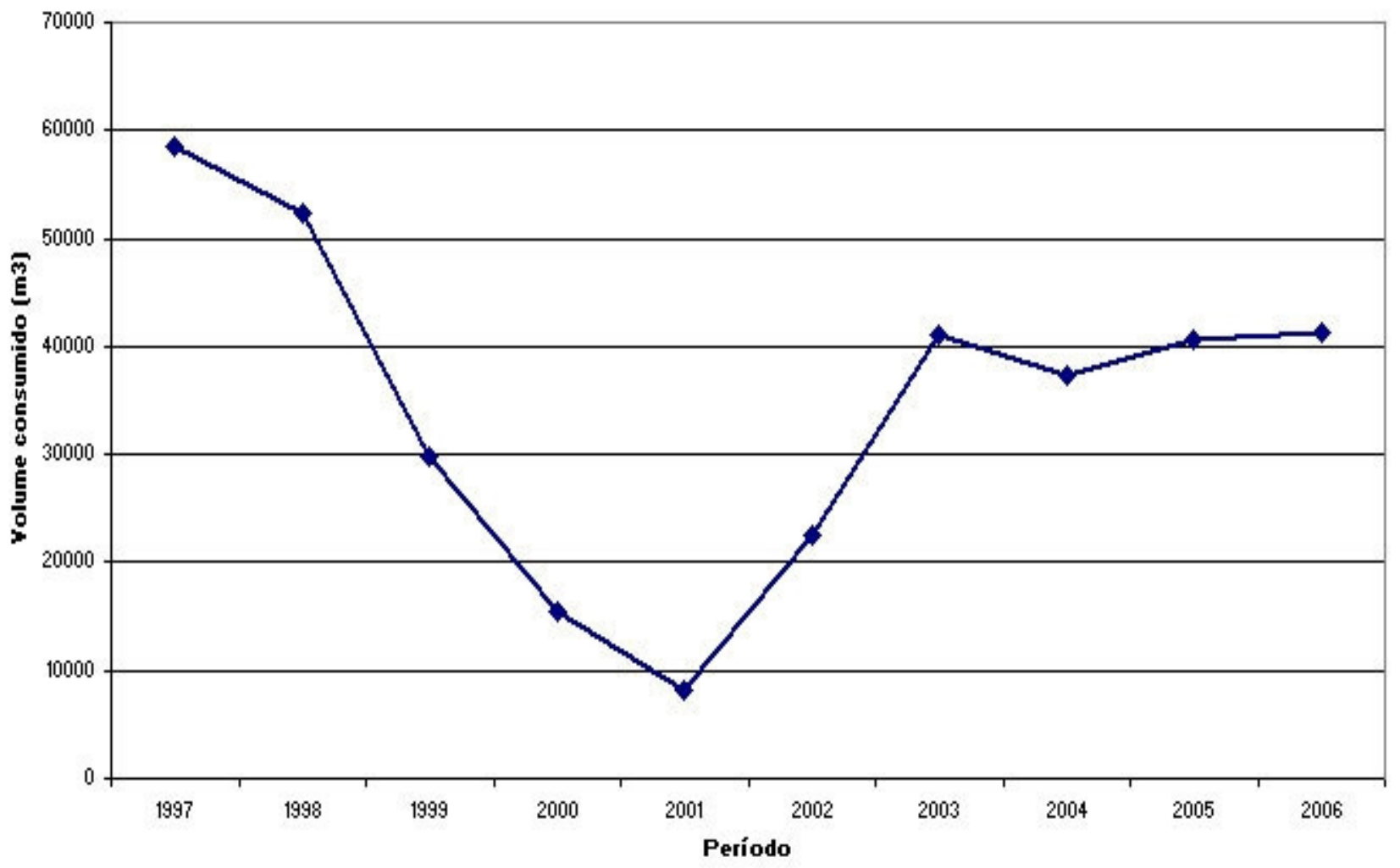

Figura 37 - Volume consumido pela categoria Industrial entre os anos de 1997 e 2006. Fonte: SAAE, 2007. Organizado por Rodrigues, 2007.

Seguindo esta linha apresentaremos os gráficos referentes ao faturamento do SAAE em reais no mesmo período (1997-2006) sabendo que não ocorreram 
modificações significativas no valor do metro cúbico da água neste tempo. Como base para os cálculos foram usados os valores referentes ao valor do real de 2006.

O gráfico que mostra o faturamento do SAAE com o setor residencial (Figura 38) indica um crescimento constante do faturamento entre pequenas oscilações, este fato está associado ao aumento natural da população do município (Tabela 1) e, por conseguinte, um aumento no número de consumidores.

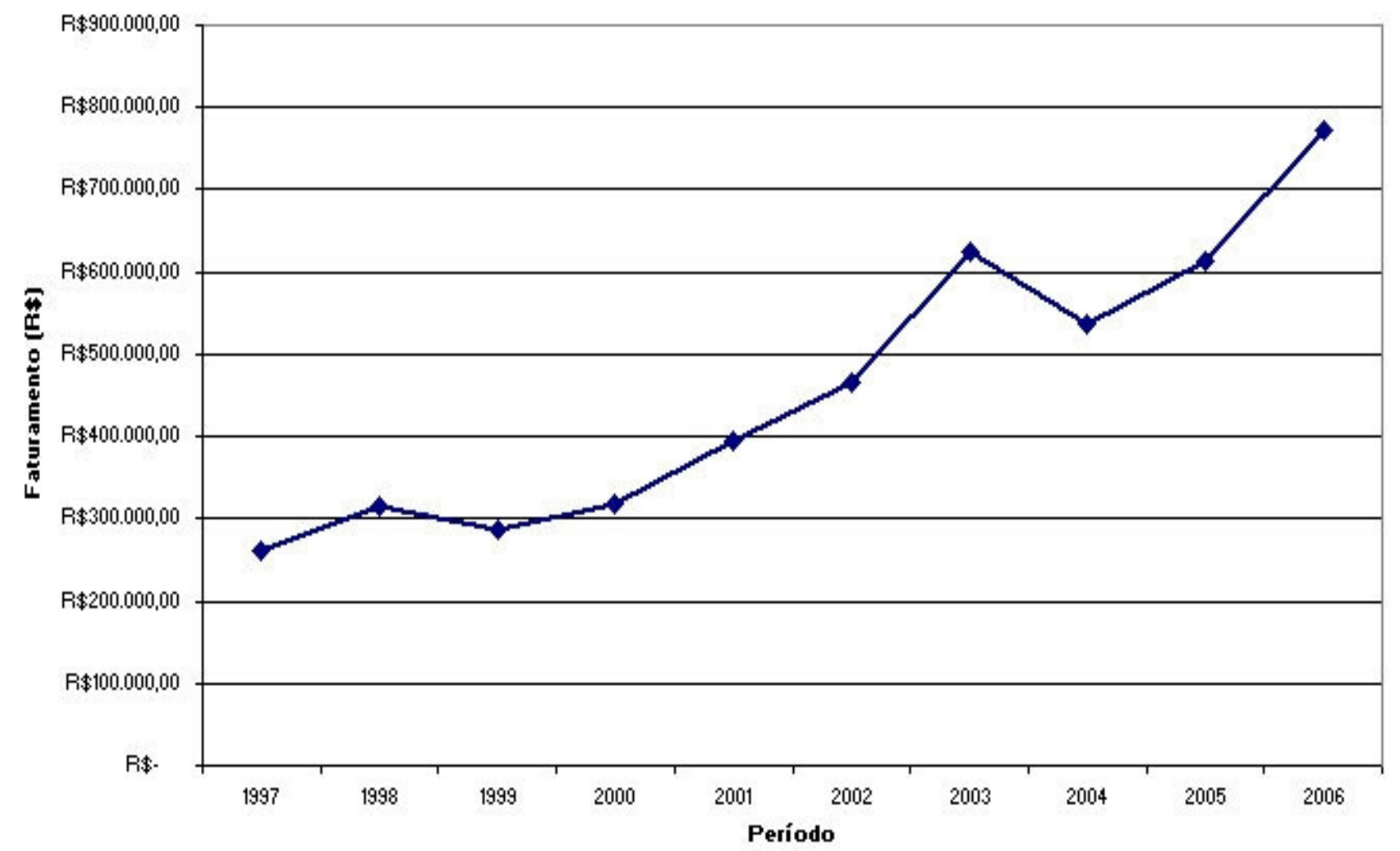

Figura 38 - Faturamento do SAAE na categoria residencial entre os anos de 1997 e 2006.

Fonte: SAAE, 2007. Organizado por Rodrigues, 2007. 
Com relação ao faturamento na categoria comercial (Figura 39), podemos observar uma queda de 1997 até 2002 e após este período, um aumento significativo na arrecadação do SAAE. Nota-se que o período mais crítico coincide com a pior fase enfrentada pelo município no que diz respeito à escassez de água para abastecimento público. Certamente esta diminuição ocorreu em virtude da redução da água oferecida pela autarquia, uma vez que o município passava por severos racionamentos naquela época.

O crescimento da arrecadação a partir de 2003 se deve a um aumento do número de estabelecimentos comerciais no município e na oferta de água pelo SAAE, uma vez que estes anos apresentaram índices pluviométricos maiores que os anteriores.

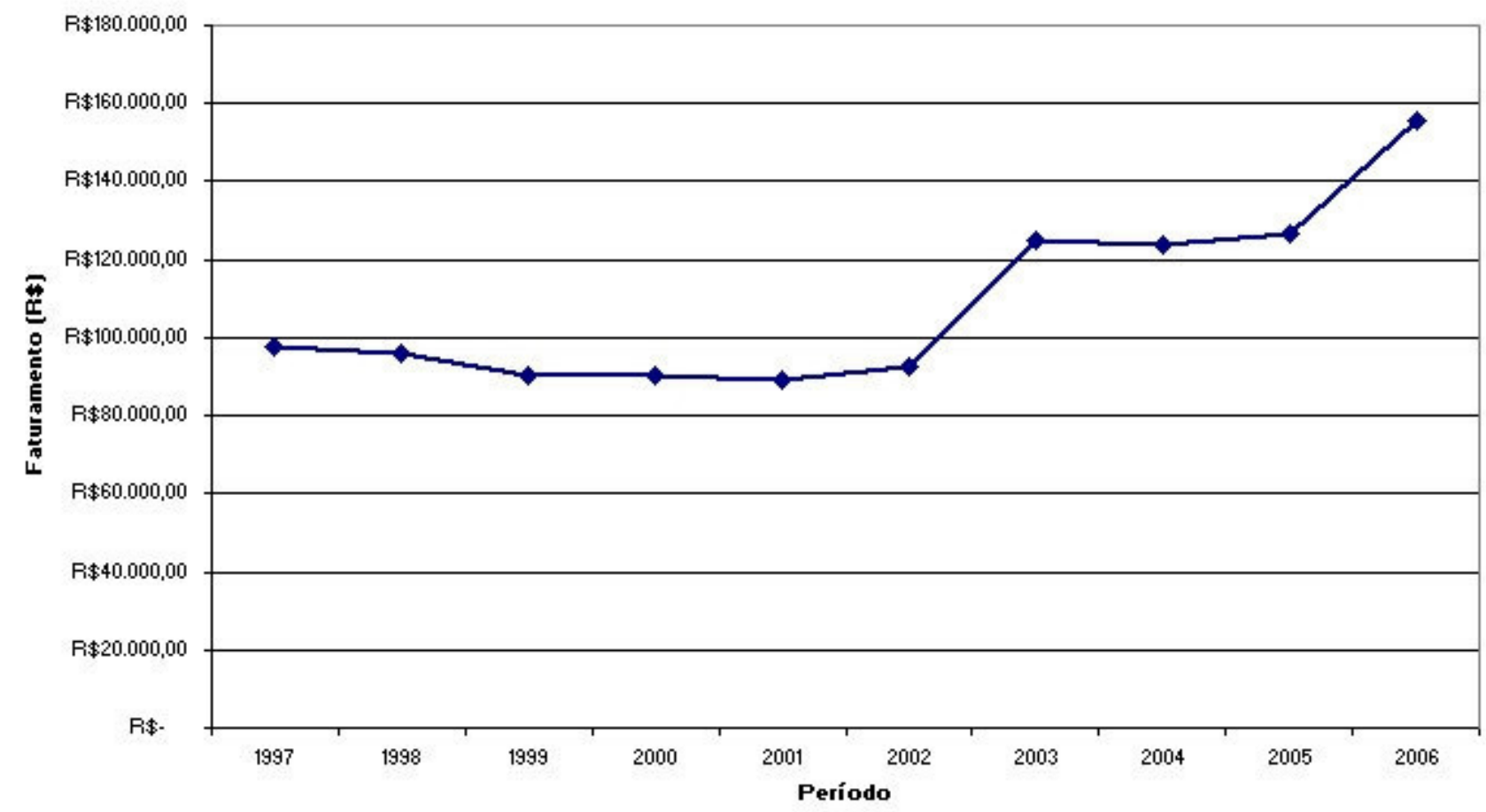

Figura 39 - Faturamento do SAAE na categoria comercial entre os anos de 1997 e 2006.

Fonte: SAAE, 2007. Organizado por Rodrigues, 2007. 
No setor industrial os números impressionam. de 1997 até 2001 a arrecadação caiu $700 \%$ (Figura 40) o que mostra a fragilidade do sistema de água do município de Itu. Com esta vertiginosa queda na categoria de sua maior arrecadação, diminuíram os investimentos do SAAE no setor de abastecimento de água e de esgoto. Esse fato atrelado à diminuição constante da demanda por parte das indústrias como já dito anteriormente, deixou o SAAE cada vez mais fraco e sem recursos. Não identificamos o fato causador do expressivo aumento no faturamento no ano de 2005 e posterior queda no ano de 2006, mas tendo como referência um pequeno crescimento na arrecadação dos setores residencial e comercial nestes anos, acreditamos em falha nos dados de 2005.

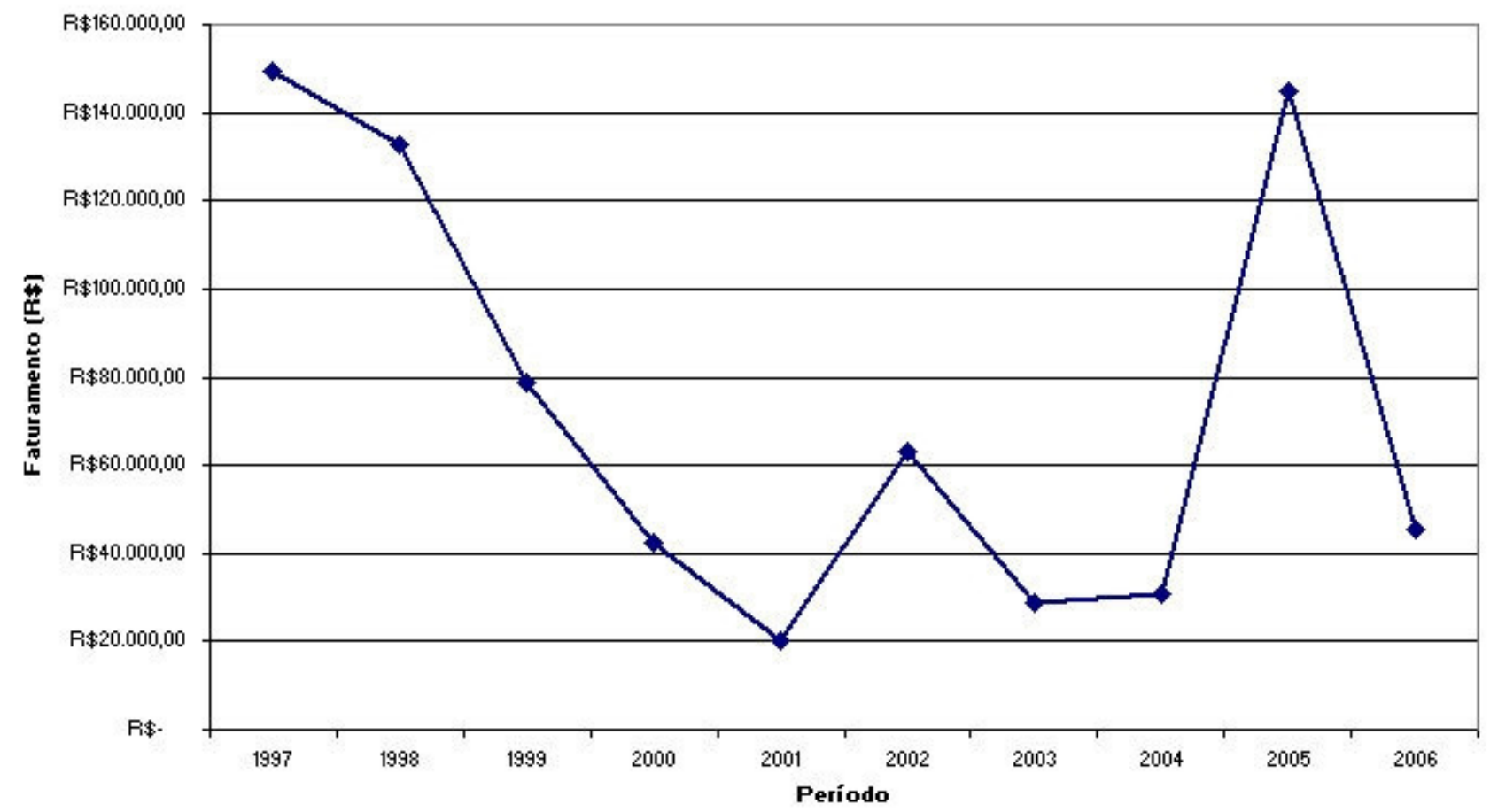

Figura 40 - Faturamento do SAAE na categoria industrial entre os anos de 1997 e 2006.

Fonte: SAAE, 2007. Organizado por Rodrigues, 2007. 
Pela análise das informações contidas nos gráficos acima, fica evidente uma grande perda na arrecadação do SAAE nos setores industrial e comercial. Isso faz com que a autarquia reduza seu caixa e tenha cada vez menos capital para realizar investimentos visando à melhoria do sistema de água. A arrecadação cai porque o SAAE não consegue fornecer a quantidade de água necessária para o bom funcionamento do comércio e principalmente das indústrias, e estas por sua vez passam a comprar água de particulares. Como conseqüência desta situação (já citada anteriormente), cresce cada vez mais em Itu um mercado paralelo de água que prejudica o próprio serviço municipal, mas que enriquece muitos empresários locais.

O mais curioso é que pudemos constatar que há muito tempo pessoas se aproveitam desta situação para enriquecer-se, comercializar água e estabelecer uma concorrência desleal com a própria autarquia já que estes empresários possuem uma infra-estrutura muito melhor que a do SAAE. Claro que impera a lei de mercado e o principal culpado por esta situação é o próprio poder público que passou a oferecer um serviço de abastecimento de água cada vez pior, o que permitiu que este tipo de prática ocorresse.

Baseando-nos mais uma vez nos escritos de Nardy Filho, pudemos comprovar que há séculos atrás já existia o comércio paralelo de água em Itu:

Em 1877 luctando com a falta de água, ia vivendo a população de Ytu (...) dando lucros aos que faziam o commercio da venda de água em pipas. (NARDY FILHO, 1999, vol.1, p.219). 
Pela citação acima podemos concluir que há mais de um século este tipo de comércio extremamente lucrativo existe no município em questão, e o que se verifica é que ele aumenta gradativamente. A cada ano cresce o número de poços artesianos perfurados bem como o represamento de pequenos córregos em áreas particulares. Esta prática está relacionada a um aumento no comércio da água na época da escassez para abastecimento público.

As conseqüências deste tipo de atividade são muitas, algumas positivas como uma maior oferta de água nas épocas críticas - as classes mais abastadas são favorecidas diretamente e diminui a pressão sobre o serviço público que passa a ter uma oferta maior do recurso favorecendo as classes menos abastadas que dependem deste serviço - e a geração direta ou indireta de empregos definitivos ou temporários. Dentre os desdobramentos negativos podemos destacar, a visível perda de arrecadação do SAAE, a utilização excessiva dos recursos hídricos superficiais e subsuperficiais, além de um fluxo constante de caminhões pipa nas ruas (com conseqüências ruins para o trânsito como uma maior lentidão, além de danificar o asfaltamento do município).

Os reflexos do problema da falta de água na economia ituana são tão fortes que afetam inclusive o Produto Interno Bruto (PIB) municipal (Figura 41). Se analisarmos o PIB do município entre 1999 a 2004, percebemos uma nítida queda de 1999 a 2001 voltando a subir em 2002. Esta queda coincide com o período mais crítico do problema, e mostra que existe uma relação direta entre a problemática da falta de água e a economia de Itu. Certamente inúmeros foram os prejuízos econômicos acumulados pelo município nesta fase. 


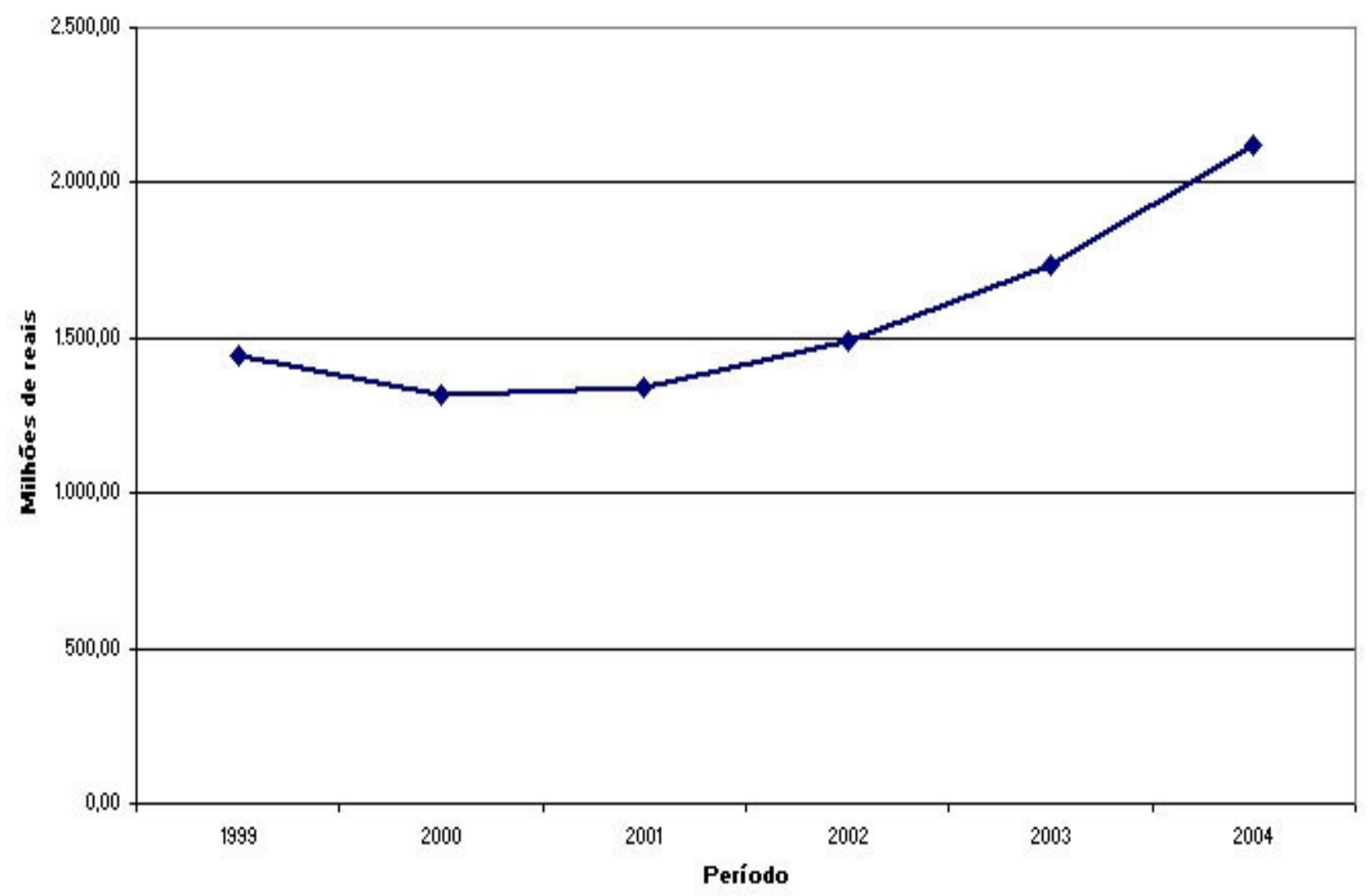

Figura 41 - Evolução do PIB do município de Itu em milhões de reais entre os anos de 1999 e 2004.

Fonte: IBGE, 2007. Organizado por Rodrigues, 2007.

Neste outro gráfico (Figura 42) podemos perceber que a participação do município no PIB do Estado de São Paulo caiu neste mesmo período, o que reforça a idéia de que o problema da falta de água interfere negativamente na economia municipal. 


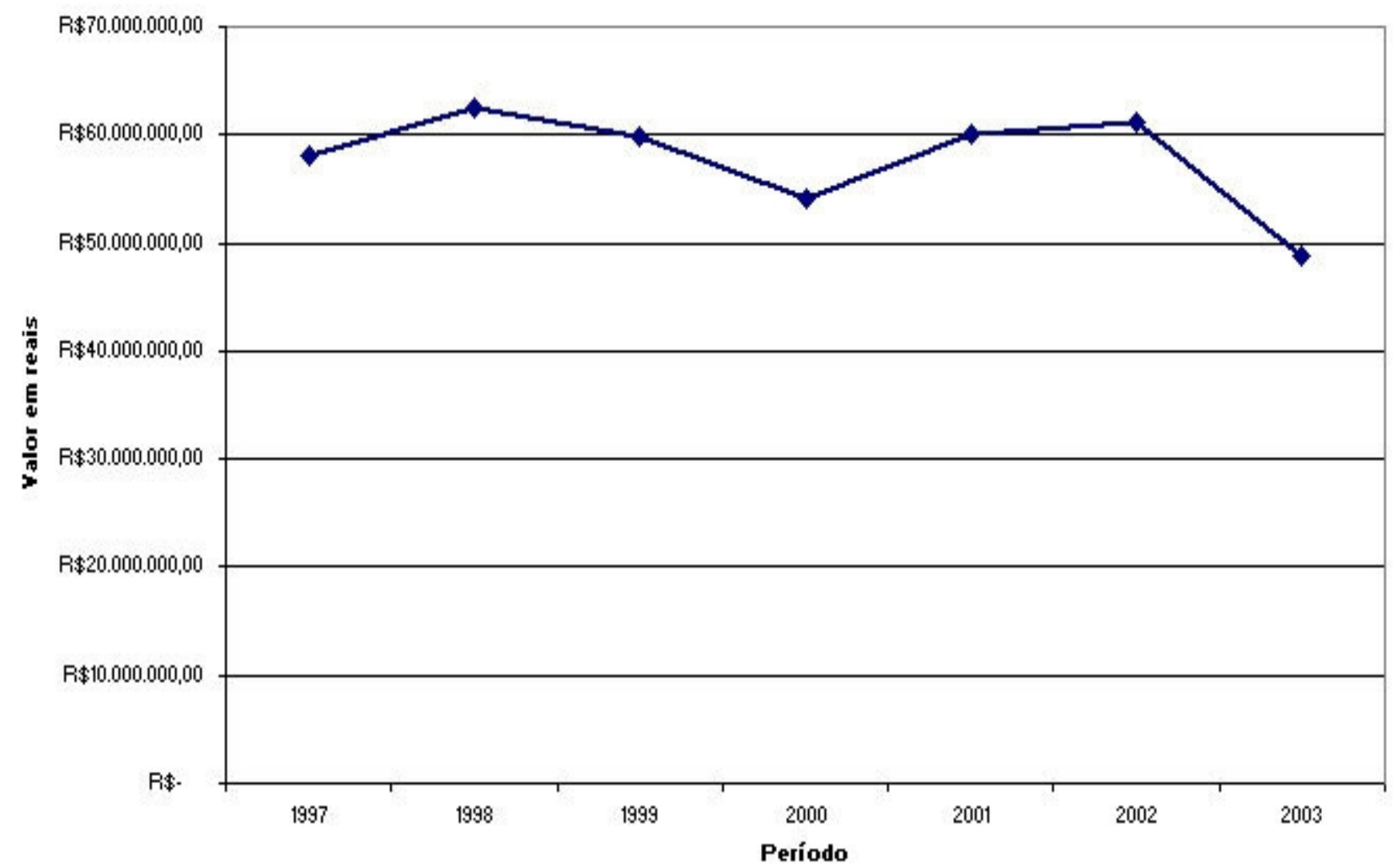

Figura 42 - Total da participação do município de Itu na receita do Estado de São Paulo em reais entre os anos de 1997 e 2003.

Fonte: IBGE, 2007. Organizado por Rodrigues, 2007.

Por todos os dados que foram mostrados neste subitem, podemos ter a noção real de quanto o município de Itu é prejudicado economicamente pela falta de água para abastecimento público. 
10.1.2 - Reflexos sociais da falta de água para abastecimento público no município de Itu-SP

Diversos são os reflexos sociais do problema da falta de água em Itu, a começar pela queda na qualidade de vida da população. A água é um elemento vital a todo ser vivo e a dificuldade de acesso ou ausência deste recurso traz diversos problemas e em alguns casos até a morte. Em Itu, a população em geral sofre com o problema, que atinge todas as classes sociais, mas sem dúvida as que mais sentem são as menos favorecidas. Enquanto a parcela mais rica soluciona rapidamente a questão comprando água de particulares, os mais carentes vivenciam dia-a-dia o problema, pois dependem totalmente do serviço público. Nos períodos de racionamento, creches, escolas, asilos, hospitais públicos e os bairros mais pobres chegam a ficar mais de 12 horas sem água acarretando a suspensão parcial ou total de suas atividades. Imaginemos os desdobramentos presentes e futuros desta situação que há muito tempo acontece em Itu durante os racionamentos, períodos mais curtos de atendimento das creches, aulas mais curtas ou suspensas, asilos sem água e até mesmo hospitais apelando para doações de água de particulares. Isso sem contar o comércio e principalmente as indústrias locais que muitas vezes tiveram que diminuir sua produção devido à escassez de água, e promoveram férias coletivas ou mesmo demitiram funcionários. Há ainda casos de empresas que não se instalam no município, ou mesmo que se mudam para outros locais onde a oferta de água é maior e dificilmente enfrentariam este tipo de problema, como declararam as pessoas entrevistadas neste capítulo. Os fatores relacionados acima reforçam os dados mostrados por meio de tabelas e gráficos de que Itu foi o município que menos cresceu e 
que mais diminuiu a participação no número de estabelecimentos industriais da região na última década.

Um outro caso que merece destaque é o da saúde pública. Em anos de racionamentos severos, a população fica a mercê de muitas doenças causadas pela contaminação da água que é armazenada em recipientes impróprios. Como uma grande parcela da população carente não possui caixa d'água ou possui caixas pequenas como pouca capacidade, costumam guardá-la em tambores e latões na tentativa de aumentar sua oferta. Isso ocorre, pois sabem que só terão o recurso disponível em suas torneiras dentro de muitas horas ou até dias, como nos casos de pequenas comunidades rurais afastadas do centro urbano principal. Essa prática ocasiona um risco bem maior de doenças que são transmitidas pela água contaminada, como parasitas que provocam infecções digestivas e estomacais entre outras.

Analisando os gastos do município de Itu com saúde, pudemos observar um relevante aumento no gastos nos anos de 1999, 2000 e 2001, o período mais crítico enfrentado pelo município no que diz respeito à escassez de água. Pelos dados do gráfico abaixo fica claro que o município gastou mais em saúde nos anos onde o problema foi mais grave. (Figura 43). 


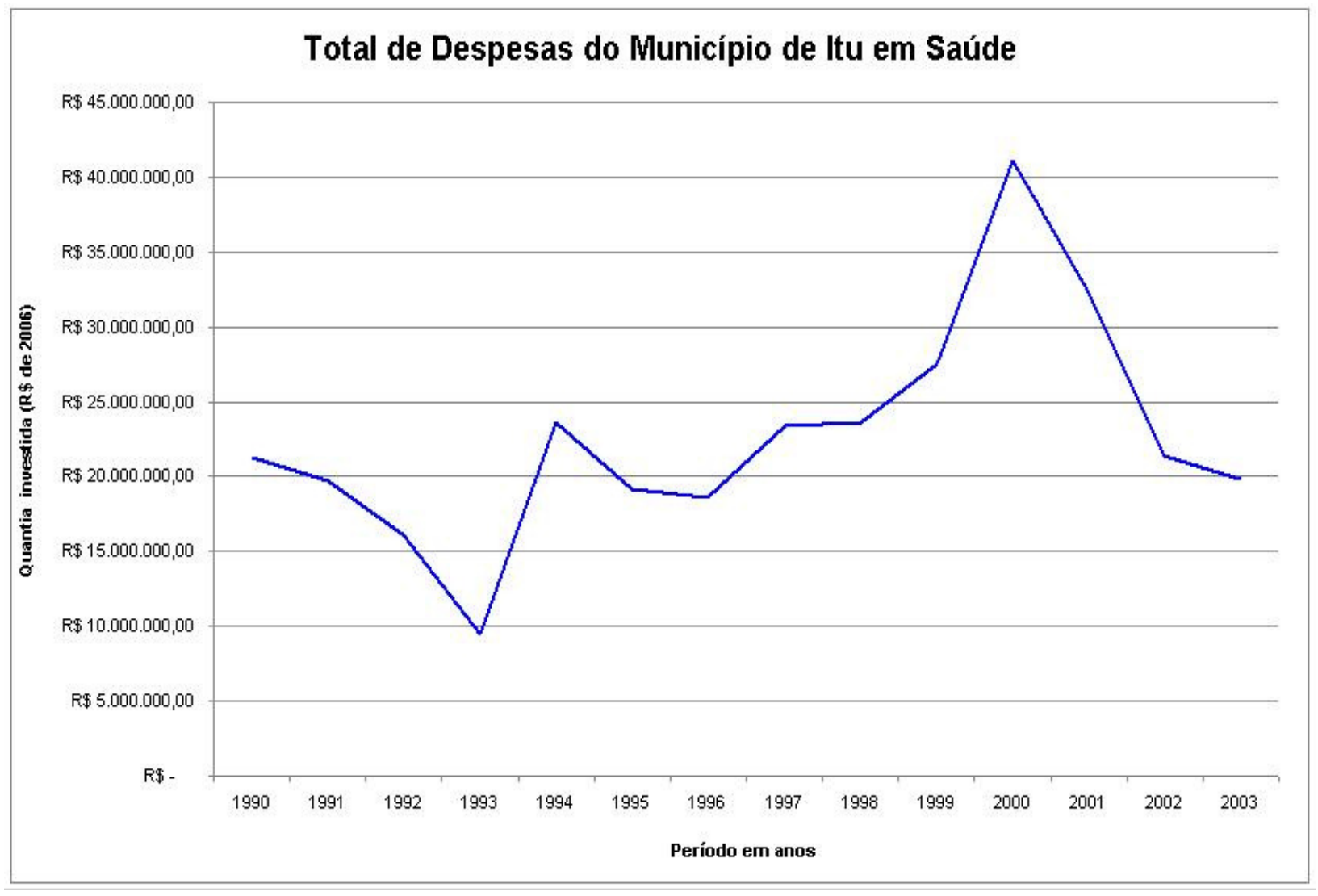

Figura 43 - Total de despesas do município de Itu em saúde entre 1990 - 2003. Fonte: SEADE, 2008. Organizado por Rodrigues, 2008.

Esses dados nos provam que a problemática da água interfere significativamente também nos setores sociais de Itu, o que contribui para um maior gasto por parte do poder público municipal quando o período de escassez de água e os racionamentos ocorrem. 


\section{1 - Considerações Finais}

Na presente dissertação, pudemos realizar uma análise do problema da escassez de água para abastecimento público que atinge o município de Itu-SP. Primeiramente, nos deparamos com a dimensão real do problema. Depois pudemos constatar que se trata de um problema secular, e, apesar de sempre causar muitos tormentos à população ao longo de todo este período, nunca foi abordado conscientemente ou enfrentado de maneira a solucionar a questão definitivamente. O descaso de muitas administrações e a falta de uma política pública adequada fizeram com que o problema atingisse proporções inimagináveis e deixasse o município de Itu por diversas vezes à beira de um colapso.

Ao invés de tentar resolver a questão, ou ao menos contribuir para tal, muitas administrações tentaram alegar uma justificativa "natural" para a falta de água. Sustentaram por décadas a idéia de que a falta de chuvas era a causadora máxima do problema, quando, na verdade, a falta de uma política séria e de investimentos reais no setor sempre foram os verdadeiros responsáveis pelas muitas situações calamitosas enfrentadas pelo município de Itu. Diversos políticos inclusive tiveram como lema de sua campanha eleitoral "a solução do problema da falta de água", mas depois que se elegeram pouco ou nada fizeram para minimizar os reflexos da problemática na vida do povo ituano.

O próprio Serviço Autônomo de Água e Esgoto de Itu (SAAE), criado na década de 70 nunca conseguiu melhorar significativamente a qualidade dos serviços de saneamento prestados à população. Apesar do nome, na prática o SAAE nunca foi autônomo, sempre sofreu interferência direta do poder público local, sobretudo, em épocas de transição de governo. Por diversas vezes o governo local retirou dinheiro do SAAE, fruto da 
arrecadação com o comércio de água, para quitar folhas de pagamento de outros departamentos municipais que nada tinham a ver com ele.

É evidente que, se o repasse de dinheiro é pequeno, e os lucros gerados dentro da autarquia são redirecionados, fica praticamente impossível administrar o setor oferecendo um serviço de qualidade. Como poderão ser feitos novos investimentos visando a melhoria do sistema de saneamento sem dinheiro para tal? Sem investimentos no setor de água e esgoto de Itu a queda na qualidade dos serviços foi inevitável, com o passar dos anos, o SAAE começou a perder campo para as empresas privadas que ofereciam um serviço mais eficiente e de qualidade superior.

Mesmo pagando mais pela água fornecida por particulares, muitos setores do município de Itu passaram a adquirir o recurso destas empresas. O maior exemplo foram as indústrias, que eram as principais compradoras de água do SAAE, e, também, as maiores responsáveis pela arrecadação da autarquia. Com a queda da arrecadação no setor secundário, a qualidade dos serviços prestados à população piorou ainda mais, levando o SAAE ao colapso. A partir de então, o poder público municipal resolveu conceder os serviços operacionais de saneamento para a iniciativa privada por um período de trinta anos, argumentando ser a melhor solução para o problema no estágio em que se encontrava.

Diante do quadro vivido pelo Serviço de Água e Esgoto de Itu nas últimas décadas e da intensificação do problema, os reflexos da escassez de água para abastecimento público foram muitos, e em âmbito econômico pudemos comprovar o quanto o município foi afetado nas últimas décadas.

Os dados nos mostraram que dentre os municípios da região analisados, Itu foi o que teve o menor acréscimo industrial nos últimos vinte e cinco anos. Da mesma forma 
diminuiu significativamente sua participação no número de estabelecimentos industriais da região, passou do segundo lugar entre os cinco municípios analisados para o último em pouco mais de vinte anos.

Ficou claro que o problema do abastecimento público de água influenciou significativamente nestes números, uma vez que a água é um elemento indispensável na maioria das fábricas e a escassez dela provoca muitos problemas. As indústrias que estão localizadas no município de Itu passaram por muitas dificuldades durante os últimos anos devido à problemática da escassez de água para abastecimento público, isso sem dúvida prejudicou de diversas maneiras a economia local.

A economia do município de Itu apresentou nos anos de 1999, 2000 e 2001 uma relação direta com a escassez de água o que indicou que produção industrial e o comércio foram afetados, influenciando na diminuição do PIB local e em uma menor participação do município na receita do Estado de São Paulo.

As conseqüências sociais da escassez de água para abastecimento público também foram muitas durante todo o tempo em que Itu a enfrentou. Porém com a intensificação do problema nas últimas décadas (70, 80 e 90), os reflexos da situação passaram a atingir um número maior de pessoas, principalmente as de baixa renda. Um exemplo é a dificuldade de se obter água para afazeres básicos do dia-a-dia como tomar um banho ou preparar alimentos. A necessidade de conseguir e principalmente de armazenar o recurso de alguma forma, o que geralmente não é feito de maneira adequada, provoca a contaminação desta água e, consequentemente, diversos problemas de saúde para quem a consumir. O resultado deste quadro comum no município de ltu é um gasto maior com saúde. 
Um outro problema social gerado pela falta de água é o desemprego industrial ocasionado por uma menor produção fabril em Itu. Isso pode ocorrer periodicamente durante o racionamento, ou pelo fato de menos indústrias terem escolhido o município para se instalar nas últimas décadas, ou mesmo por algumas terem se mudado. É evidente que ao conhecer o problema, uma indústria que necessite bastante do recurso não vai optar por se instalar em Itu, ou mesmo uma que já está instalada, mas que acumula prejuízos em épocas de racionamento, pode optar por se mudar para outro lugar. O comércio local também é afetado de diversas maneiras como no caso de restaurantes e bares que em épocas de racionamento ficam sem o recurso vital para seu funcionamento. Além disso, se menos pessoas trabalham, menor será o consumo e maior será o prejuízo no setor.

Comumente as escolas reduzem o seu período de funcionamento durante os racionamentos, o que resulta em uma piora na formação dos alunos. Podemos imaginar os impactos a curto, médio e longo prazo gerados por essa situação tendo como base a importância da educação e a freqüência com que estes racionamentos acontecem no município de Itu.

Enfim, a problemática é extremamente séria, portanto merece prioridade e total atenção do poder público municipal, não se deve deixar que a questão seja usada em âmbito político ou econômico para benefício de alguns, enquanto a maioria da população ituana sofre graves conseqüências. É preciso agir de forma determinada a enfrentar e resolver o problema por meio de uma política pública correta e direcionada. Como a opção foi a de conceder o setor de saneamento a iniciativa privada, cabe ao município por meio do SAAE e a população fiscalizar as ações da concessionária e exigir um serviço de qualidade a um preço justo. 
Sem dúvida, este seria o mais importante passo a ser tomado na tentativa de melhorar o quadro socioeconômico do município de Itu-SP, e, consequentemente, a qualidade de vida de seus habitantes. Espera-se que o problema da escassez de água para abastecimento público em Itu seja solucionado ou ao menos amenizado num futuro próximo, e que esta pesquisa possa contribuir de alguma forma para que isso aconteça. 


\section{2 - Referências Bibliográficas}

AB'SABER, A. N. A terra paulista. Boletim Paulista de Geografia. São Paulo-SP, 1956.

ALMEIDA, F. F. M. de. Fundamentos geológicos do relevo paulista. Bol. Inst. Geogr. e Geol., IGG, (41): 169-263 , São Paulo-SP, 1964.

ALUCCI, M. P; CARDIA, N; VARGAS, M. C. Subsídios às campanhas de educação pública voltadas à economia de água. Brasília, Programa Nacional de Combate ao Desperdício de Água (PNCDA), Ministério do Planejamento e Orçamento, Brasília-DF, 1998.

ALVES, R. F. F; CORNEJO, J. G. L; MIRANDA, E. C. de; SILVA, R. T. Indicadores de perdas nos sistemas de abastecimento de água. Brasília, Programa Nacional de Combate ao Desperdício de Água (PNCDA), Ministério do Planejamento e Orçamento, Brasília-DF, 1998.

BRAGA, R. \& CARVALHO, P. F. (org). Recursos hídricos e planejamento urbano regional. LPM, DEPLAN, UNESP, Rio Claro-SP, 2003. 
CNS - CONFERÊNCIA NACIONAL DE SANEAMENTO - Comissão de Desenvolvimento Urbano e Interior da Câmara Federal - Subcomissão de Saneamento. Relatório síntese da conferência nacional de saneamento. Brasília-DF, 1999.

DEPARTAMENTO de GEOLOGIA APLICADA - DGA. Subsídios para elaboração do plano diretor de águas da Estância Turística de Itu/SP. Relatório Técnico. Fundunesp, UNESP, Rio Claro-SP, 1998.

EMPRESA BRASILEIRA DE PESQUISA AGROPECUÁRIA - EMBRAPA. Sistema brasileiro de classificação de solos. Centro Nacional de Pesquisa de Solos. 412p. Brasília, 1999. Disponível em: http://www.cnps.embrapa.br/ Acesso em 15 Mar. 2007.

ENDONUCLEUM SERVIÇOS S/C Ltda. Diagnóstico do sistema de saneamento básico e o aproveitamento dos recursos hídricos do município de Itu. Relatório Técnico. São PauloSP, 2001.

FUNDAÇÃO GETÚLIO VARGAS - FGV. Diagnóstico total das potencialidades atuais e necessidades futuras objetivando a modelagem de alternativas institucionais e gerenciais para prestação dos serviços públicos relacionados ao abastecimento de água e saneamento básico das áreas urbanas do município de Itu. Relatório Técnico. São PauloSP, 2000. 
FUNDAÇÃO SISTEMA ESTADUAL DE ANÁLISE DE DADOS - SEADE. Sistema de informações dos municípios paulistas - IMP. Disponível em: http://www.seade.gov.br. Acesso em: 04 Jan. 2008.

FÓRUM PERMANENTE DAS RELAÇÕES UNIVERSIDADE-EMPRESA - Instituto UNIEMP. Modelagem do sistema de gestão dos serviços de água e esgoto. Relatório Técnico. São Paulo-SP, 2006.

INSTITUTO BRASILEIRO DE GEOGRAFIA E ESTATÍSTICA - IBGE. Censo demográfico 1970, 1980, 1991, 1996, 2000 e estimativa para 2007. Disponível em: http://www.ibge.gov.br Acesso em: 26 Abr. 2008.

INSTITUTO de PESQUISAS TECNOLÓGICAS do ESTADO de SÃO PAULO - IPT. Mapa geomorfológico do estado de São Paulo. Volume 1, São Paulo-SP, 1981.

INSTITUTO GEOLÓGICO - IG. Subsídios do meio físico-geológico ao planejamento do município de Itu/SP. Relatório Interno. IG/SMA, São Paulo-SP, 1991.

MONTEIRO, C. A. F. A dinâmica climática e as chuvas no estado de São Paulo: estudo geográfico sob forma de atlas. Universidade de São Paulo, Instituto de Geografia, São Paulo-SP, 1973. 
MORAES, M. C. C. C \& CORREA, M. A. S. D. Isto é Itu. Prefeitura da Estância Turística de Itu, 4ª edição, Itu-SP, 1995.

NARDY FILHO, F. A cidade de Ytu. Universidade de São Paulo, volume 1, $2^{\mathrm{a}}$ edição, Instituto Histórico e Geográfico de São Paulo, Ottoni, Itu-SP, 1999.

A cidade de Ytu. Universidade de São Paulo, volume 1, $6^{\text {a }}$ edição, Instituto Histórico e Geográfico de São Paulo, Ottoni, Itu-SP, 1999.

OGERA, R.C. \& PHILIPPI JR, A. Gestão dos serviços de água e esgoto nos municípios de Campinas, Santo André, São José dos Campos e Santos, no Período de 1996 a 2000. Rev. Eng. Sanit. Ambient., ABES, vol.10, nº1, Rio de Janeiro, Jan./Mar. 2005. Disponível em:http://www.scielo.br/scielo.php?pid=S1413-41522005000100009\&script=sci arttext Acesso em: 18 Mar. 2008.

REBOUÇAS, A. C; BRAGA, B; TUNDISI, J. G. Águas doces do Brasil; capital ecológico, uso e conservação. Escrituras, São Paulo-SP, 1999.

RIBEIRO, A. G. O consumo de água em Bauru-SP: O tempo cronológico e o tempo meteorológico aplicados na elaboração de subsídios à previsão de demanda de água. Tese de Doutorado, FFLCH - USP, São Paulo-SP, 1975. 
ROCHA-CAMPOS, A. C. 2000. Varvito de Itu-SP. In: Schobbenhaus,C.; Campos,D.A.;

Queiroz,E.T.; Winge,M.; Berbert-Born,M. (Edit.) Sítios Geológicos e Paleontológicos do Brasil. Disponível em: http://www.unb.br/ig/sigep/sitio062/sitio 062.htm Acesso em: 15 Abr. 2007.

RODRIGUES, M. R. O Problema do abastecimento público de água em Itu/SP: Uma abordagem geográfica com ênfase nos aspectos climatológicos. TCC, UNESP, Rio ClaroSP, 2003.

TUNDISI, J. G. Água no Século XXI; enfrentando a escassez. Rima/IIE. São Carlos-SP, 2003. 
ABASTECIMENTO SAEE suspende o fornecimento das 8hàs 18 h diariamente; região não tem chuva agricola há 54 dias

\section{Itu tem corte de água em toda a cidade}

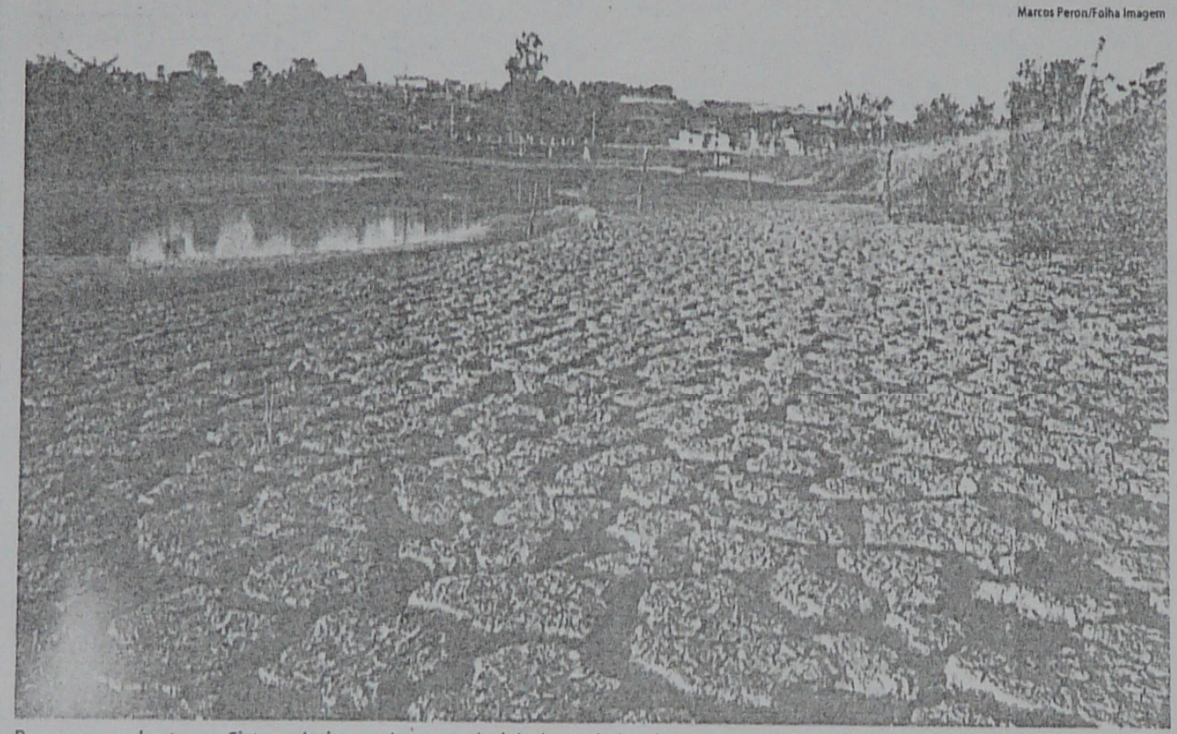

Represa que abastece o Sistema Itaim, em Itu, com nivel de água abaixo do normal; problemas no abastecimento preocupa escolas

\section{Região tem índice de chuvas 30\% abaixo do normal}

DAFOLHACAMPINAS

Um levantamento feito pelo $\mathrm{Ce}$ pagri da Unicamp mostra que as chuvas de primavera e verão ficaram cerca de 300 milímetros abaixo do normal na regiāo, o que provocou a antecipação da estiagem registrada entre julho e outubro. 0 indice de chuvas ficou $30 \%$ abaixo do registrado em 99 .

"Choveu inuito pouco no verä̀o. Entre os meses de outubro e marco tivemos 900 milimetros de chuva, quando esperávamos 1.200 milimetros", disse o coordenador do Cepagri, Hiltom Silveir

A falta de chuva provoca a diminuiçâo da água nos ríos e consequente prejuizo ao abastecimento. Outra consequència, segundo - Cepagri, é a secagem das fontes de abastecimento de água para irrigaçäo.

Com a estiagem, as chances de ocorreremincèndios aumentame agravam os indices de poluição.
As perspectivas nã̃o sẵo animadoras. A previsão do Cepagri é que só volte a chover na regiāo a partirde outubro.

\section{Abastecimento}

Segundo o Grupo Técnico de Monitoramente Hidrológico, o Sistema Cantareiras, responsável pelo abastecimento da regiảo metropolitana de São Paulo, pode não cumprir o papel estratégico na liberação de água para as cathas dos rios Atibaia e Jaguari, que normalmente ocorre nos mes de julho, agostoe setembro. A liberação de água garante uma vazão minima no rio Piracicaba e diminui, em seu percurso as áquas poluidoras Com a ameaça de escassez, entretanto, a vazăo a Sabesp (Companhia de Saneamento Básico do Estado de São Paulo) nāo terá condicōes de aumentar a liberação de água, o que pode prejudicar 0 abastecimento na regiẫo, do rio Piracicaba deve diminuir e
DAFOLHACAMPIAS

OSAEE (Servico Autónomo de Água e Esgoto) de Itu (55 km de Campinas) começou ontem oraconamento de água em toda a cidade. A medida afeta 120 mil moradores e é por tempo indeterminado. 0 abastecimento de água está sendo cortado diariamente das 8 hàs $18 \mathrm{~h}$.

As quatro represas de água que abastecem a cidade estāo três metros abaixo no nivel considerado normal. As duas maiores, Itaim e Fubalero, têm apenas 1 metro de

Os sistemas Itaim e Fubalero juntos, são responsáveis pelo abastecimento de $70 \%$ da cidade. Os dois outros sistemas, Braiaiá e Santo Antônio, abastecem o restante do município e ontem estavam com nível de água de dois metros.

Segundo 0 diretor técnico do SAEE, José Carlos Rodrigues, preciso chover pelo menos 400 milimetros para que 0 abastedimento volte ao normal, Rodrigues afirma que a chuva tem que ser continua e durar vários dias para as represas voltarem ao nível de 3 metros deágua

De acordo com o Cepagri (Centro de Ensino e Pesquisas para Agricultura) da Unicamp (Universidade Estadual de Campinas), a região completou ontem 54 dias sem chuvas agicolas (mais de 10 milímetros por dia). Éo maior penodo de estiagem na região des 1890, segundo o Cepagri

0 racionamento parcial de água em Itu comecou há uma semana com o corte de água das $8 \mathrm{~h}$ às 18 aos moradores abastecidos pelo Inim, na zona oeste daciade. Ontem, a medida foi an pliada para toda a cidade.

O SAEE vai tomar providéncias emergenciais para tentar resolver oproblema da falta deágua. Entre las estão o desvio de córregos, a abertura de poços e o fomecimento de caminhōes-pipas para bastecer escolas e postos.

Ontem, segundo a Secretaria do Governo de ltu, nenhum setor foi prejudicado pela falta de água. 0 SAEE, entretanto, prevế que a siuncẫo se agrave caso não chova nos próximos dias.

A possibilidade é que o racionamento nāo fique restrito a um perodo do dia, mas seja ampliado para 24hem dias alternados

Segundo o Grupo Técnico de Monitoramento Hidrológico, que esteve reunido no último dia 12 em Americana (28 km de Campi nas), a regiäo corre risco de en frentar crise no abastecimento nospróximosmeses.

Caso a estiagem continue, a previsāo do grupo de monitoramento é que no fim de julho toda a regiāo tenha que racionar água. Em Sumaré (26 km de Campinas), por exemplo, ainda nāo há isco de racionamento, mas o BAE (Departamento de Água e Esgoto) detertou que a represa do Marcelo, responsável pela metade do abastecimento da cidade junto com a represa do Horto, teve queda de volume de $3 \mathrm{~cm}$ por dia.

Em Campinas nāo há risco de racionamento,

$\rightarrow$ LEIAMALS sobre estiagem na pàg. C7 


\section{REPÚBLICA}

\section{Desperdício de água acarreta multa de $\mathrm{R} \$ 147$}

\section{CRISTIANE GUIMARÁES}

ITU - 0 racionamento de água em toda cidade, que começou segunda-feira, não têm data prevista para ser suspenso. Diariamente, pelo período mínimo de dez horas, o fornecimento de água é suspenso em todo município, atingindo mais de 120 mil habitantes. Esta semana, o Serviço Autônomo de Água (Saae) divulgou que iniciará um trabalho intenso de fiscalização contra 0 desperdício. A multa para 0 morador que desperdiçar água é de RS 147,71.

Na semana em que anunciou 0 racionamento, o diretor técnico do Saae, José Carlos Rodrigues, declarou que a estiagem deste ano é uma das mais fortes que já atingiu o municipio. No ano passado, 0 racionamento aconteceu no més de outubro. "A situa- ção é preocupante porque artigo $1^{\circ}$, parágrafo único, não há previsōes de chuvas para o próximo més", disse. "Racionar foi a solução encontrada para enfrentar a estiagem".

A previsão do tempo de hoje para o Estado de São Paulo, segundo o Instituto Nacional de Meteorologia (Inmet) é de parcialmente nublado - a nublado, com possibilidades de chuvas em áreas isoladas e fracas na região leste. No ano passado, quando houve o último racionamento, Rodrigues declarou que 0 restabelecimento do nível das represas dependia de chuvas continuas por vários dias.

Para evitar desperdícios, equipes do Saae foram colocadas nas ruas para percorrer os bairros, baseadas na lei que dispõe sobre a obrigatoriedade de evitar 0 desperdício em período de estiagem. En seu fica estabelecido que é considerado desperdício o uso de água para lavagem de varandas, quintais, calçadas e automóveis, a irrigação de jardins e a substituição ou reposição da água da piscina.

A lei estabelece ainda que a primeira infraçâo será punida com advertência e a segunda com multa. No início desta semana, Rodrigues disse que a multa será aplicada apenas depois da advertência. A multa estabelecida para o desperdício é de R\$ 147 , 71 - R\$ 3,29 abaixo de um salário mínimo. Em caso de reincidência, 0 valor será dobrado e chega a $R \$ 295,42$.

Segundo 0 diretor técnico, o objetivo principal da fiscalização é conscientizar a população. Reduzir 0 período dos banhos, fechar a torneira ao escovar os dentes ou fazer a barba e utilizar a água da máquina de lavar roupas para limpar 0 quintal, são atitudes que podem contribuir.

Mudança de hábito 0 racionamento diário de dez horas - em alguns pontos o periodo é maior, como é o caso de trechos do Presidente Médici e São José - modificous a rotina das donas-de-casa. "Estou lavando roupa às 5 he e aproveito para guardar água para fazer o almoso e limpar a cozinha", declarou Aparecida de Souza. Ela reside no Jardim Rancho Grande e sua casa tem uma caixa-reservatório de 250 litros. "A caixa é pequena e é melhor guardar para o banheiro", disse.

No mesmo bairro reside a dona-de-casá Joana Francisco. Ela tem dois filhos pequenos. "Eles siljam muita roupa e por isso

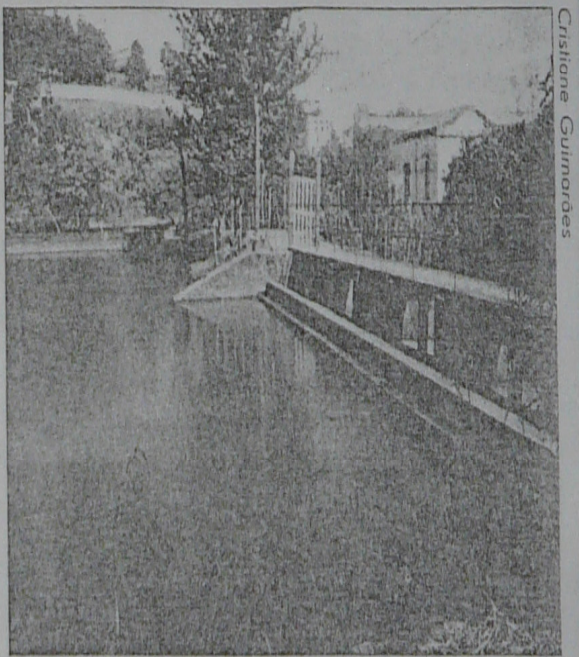

A represa do Braiciá, responsável pelo abasíecimento de mais de $70 \%$ do município

fico acordada até mais tar- do Carmo Silva, residente de para lavar Iudo". Ela do São Judas, estão levandisse que o fornecimento de do garrafinhas plásticas água é cortado por volta das com água para a escola. "As Sh e retorna pouco depois professoras pediram", codas 18h. "Para o serviço de mentou. "Para armumar a casa uso a água da caixa, casa estou levantando mais mas é preciso economizar", cedo", declarou. "Alguns declarou. "Quando acaba, dias é preciso também dejnão tem o que fazer". Xar um pouco do serviço Os filhos de Maria para a noite". 


\section{População armazena água em baldes}

\section{FREE-LANCE PARA A FOLHA CAMPINAS}

A população de Itu está reservando água em baldes e latas por causa do racionamento, que teve início há 60 dias e foi ampliado ontem peloSaae.

Segundo o Saae, cerca de 32,5 mil (25\%) dos 130 mil habitantes da cidade nầo têm reservatório em casa, principalmente no centro antigo e na periferia, e o improviso é o único meio de armazenar água.

Segundo os moradores, a água chega de madrugada e acaba pela manhä.

O aposentado Antônio Dorta, 79, disse que a falta de água é tão crítica que ele tem que comprar água mineral para beber.

"Estou pintando um tambor para reservar água para o banho e para fazer comida", disse.

O funcionário público Wanderley Borelli, 30, disse ter comprado uma caixa d'água extra para reservar água.

A dona-de-casa Ivanilde Rosa da Silva, 36, também improvisou.

Ela mantém baldes de água ao lado do tanque e disse acordar todo dia às 5 h para lavar roupa.
"Hoje a água chegou à th e, às $7 \mathrm{~h}$, já tinha acabado", afirmou.

A falta de água não é a única preocupação da dona-de-casa Maria Aparecida de Oliveira.

Ela teme que a necessidade de reservar água em baldes crie focos do mosquito Aedes aegypti, causador da dengue.

A desempregada Deise Theresinha Timóteo, 36, está reformando a casa e disse que năo tem água parafazer a limpeza.

\section{Outras cidades}

Em Várzea Paulista, o rodízio de água que começa hoje. A estiagem também preocupa os departamento de água e esgoto das cidades de Americana, Piracicaba Campinas, Paulínia e Sumaré, mas nenhuma optou, ainda, pelo racionamento.

O diretor de Operações da Sanasa (Sociedade de Abastecimento de Água e Saneamento S/A), Armando Gallo Yahn, disse que, embora o abastecimento esteja normal em Campinas, a situação é preocupante. "Esse semestre é atípico em relação aos anos anteriores, mas nāo vamos fazer racionamento", afirmou.

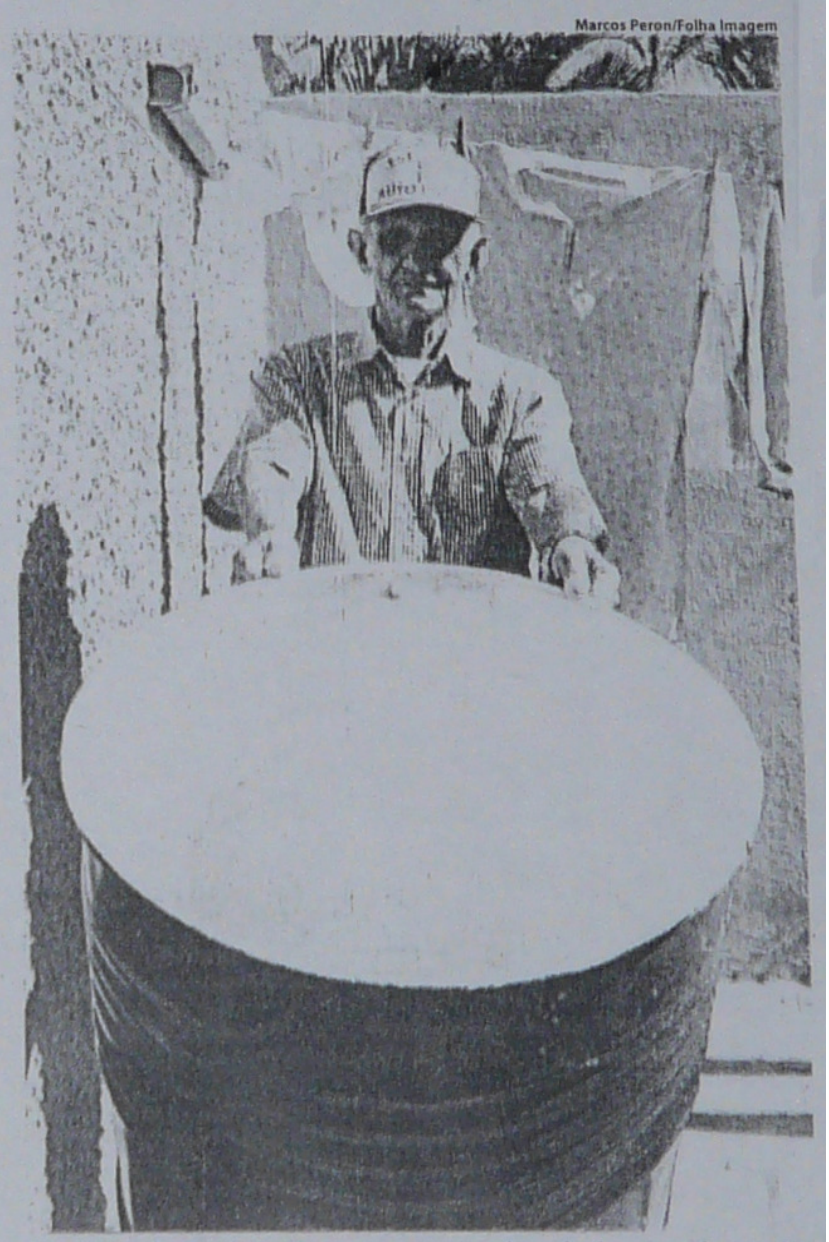

Aposentado Antônio Dorta mostra tambor de água vazio, em Itu 

socioeconômicos no município de Itu-SP.

\section{Racionamento passa a ser das $6 \mathrm{~h}$ às $22 \mathrm{~h}$}

Itu - As pessoas que já es. tão indignadas com a falta d'águ durante 0 dia em toda a cidade, ggora teráo que se adequar a ampliaçao do horário do racionamento. A partir desta semana, 0 abastecimento será interrompido das $6 \mathrm{~h}$ à $22 \mathrm{~h}$ (seráo 16 horas diárias).

Hoje, a partir das 8h, o Saae (Serviço Autônomo de Água e Esgoto) colocará uma kombi à disposicáo das pessoas que extiverem interessadas em ver a situação da represa Itaim. Um técnico da autarquia acompanhará os cidadảos e explicar toda a situaçäo arual que a cidadeatravessa. Estas visitas estaräo acontecendo durante todo o dia, de acoIdo com a lotação da kombi.

0 diretor técnico do Saae José Carlos Rodrigues, informou que a situaçáo das represas piora a cada dia, o que complica a programaçāo do racionamento. "Cedo a gente chega e as represas estāo de um jeito. $A$ tarde, já estẫo com a capacidade bem abaixo", disse. "Isso nāo nos permite programar um racionamento", completol.

Segundo José Carlos, a situaçáo da represa Fubaleiro é uma das piores no momento, superando inclusive a do Itaim. Para que a situação se normalize, é necesssá. rio chover 400 milímetros de uma forma constante, e nāo de uma única vez. Entretanto, de acordo com as previsōes, haverá chuva apenas depois do inverno, por volta do mês de outubro.

\section{Estudantes visitam barragem do Itaim}

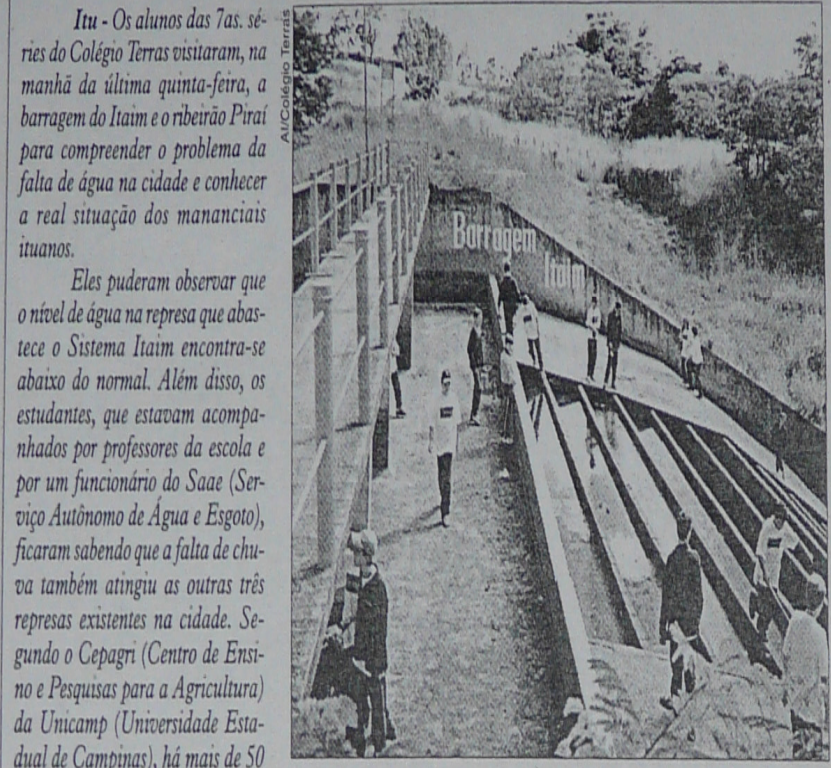

dual de Campinas, há mais de 50 dias sem chuvas fortes, a regiāo enfrenta o maior periodo de estiagem. descle 1890.

Estudantes durante visita ao Sistema Itaim

Cabreiva, os estudantes observaram realidade da água no mundo", ex-

Os estudantes também pu- um conjunto de casas precariamente plicou o professor Edson Luis deram conhecer de perto o proble- construidas por pessoas que trabalham Borsari Camargo. "Nosso objetivo ma da poluiçao que atinge o ribei- no corte de pedras, cujo esgoto e lixo é estudar Itu e partir para um proräo Piraí, principal forte de águe doméstico sío atirados diretamente no cesso de conscientizaçäo sobre a neapropriada para abastecimento da ribeirão. cessidade do racionamento e comregiäo e uma das soluçoes para a "Esta visita faz parte de um bate ao desperdicio de água além. falta de água no municipio. Em tre- projeto educacional maior, dentomina- dos limites da escola", ajumou a procho do rio ainda na cidade de do 'Agua', que comecou abordando a fessora Luisa Gertrudes de Araijo. 
Jornal Folha de São paulo

$31 / 05 / 2.000$

Quarta-feira

Marcos Peron - 27.mai.2000/Folha Imagem

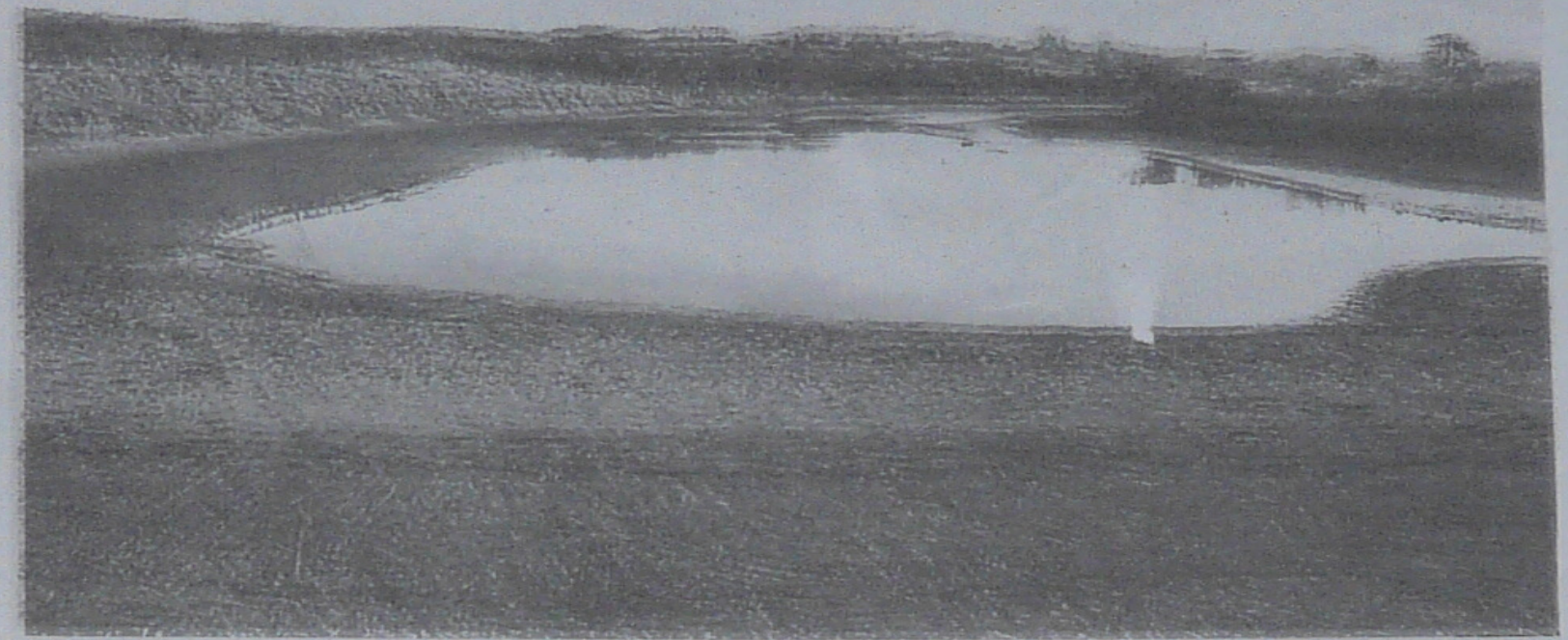

Vista da represa do Itaim com nível de água abaixo do normal; Itu enfrenta seca há 60 dias

estragem Medida deverá resultar em suspensão das aulas Itu decreta estado de calamidade

pública devido à falta d’água

\section{FREE-LANCEPARA A FOLHA CAMPINAS}

O prefeito de Itu $(55 \mathrm{~km}$ de Campinas), Leonel Salvador (PMDB) vai decretar estado de calamidade pública na cidade em razāo da falta de água que afeta e cidade há 60 dias.

O documento que descreve a situação do munić́pio será enviado hoje ao governador Mário Covas (PSDB).

A medida deve resultar na suspensão das aulas nas 15 escolas municipais. Pelo menos 7.000 alunos seräo prejudicados.

O prefeito disse que vai suspender 0 abastecimento das unidades escolares, que há 15 dias é feito por meio de um caminhão-pipa. agrícola de 15 propriedades rurais localizadas acima dos pontos onde o líquido é captado será interrompido, segundo o prefeito.

Os dois hospitais da cidade devem continuar sendo abastecidos por meio de caminhōes-pipa.

A cidade está sob estado de emergência desde de setembro do ano passado.

Segundo o diretor técnico do Saae (Serviço Autônomo de Água e Esgoto), José Carlos Rodrigues, o documento não foi revogado porque a situaçāo de seca continuou afetando a cidade.

Anteontem, o Saae decidiu aumentar o racionamento de dez horas para 16 horas. O fornecimento é cortado das $6 \mathrm{~h}$ às $22 \mathrm{~h}$.

O volume de água tratada caiu $40 \%$ nos últimos meses. 
Jornal Folha de São Paulo

$30 / 05 / 2.000$

Terça-feira

\section{FOLHACAMPINAS \\ Tel: $0 / x \times / 19 / 254-144$}
Internet: http://www.uol.com.br/isp/campinas
\[ \text { Fax: 0/xa/19/251-002 } \]
Internet: hrtp: $/ /$ www. vol.com.br/isp/campinas
\[ \text { Fax: } 0 / x / 19 / 251-0025 \]

PÁGINAC $1 \star$ SãoPAULO, TERÇA-FEIRA, 30 DE MAIO DE $2000 \star$ INCLUI COTIDIANO

Servicode

$0 / x=/ 11 / 224-3090$

cLimA Estiagem afeta o abastecimento de água da cidade há dois meses; Campinas tem temperatura mais baixa do ano

\section{Itu amplia racionamento para 16 horas}

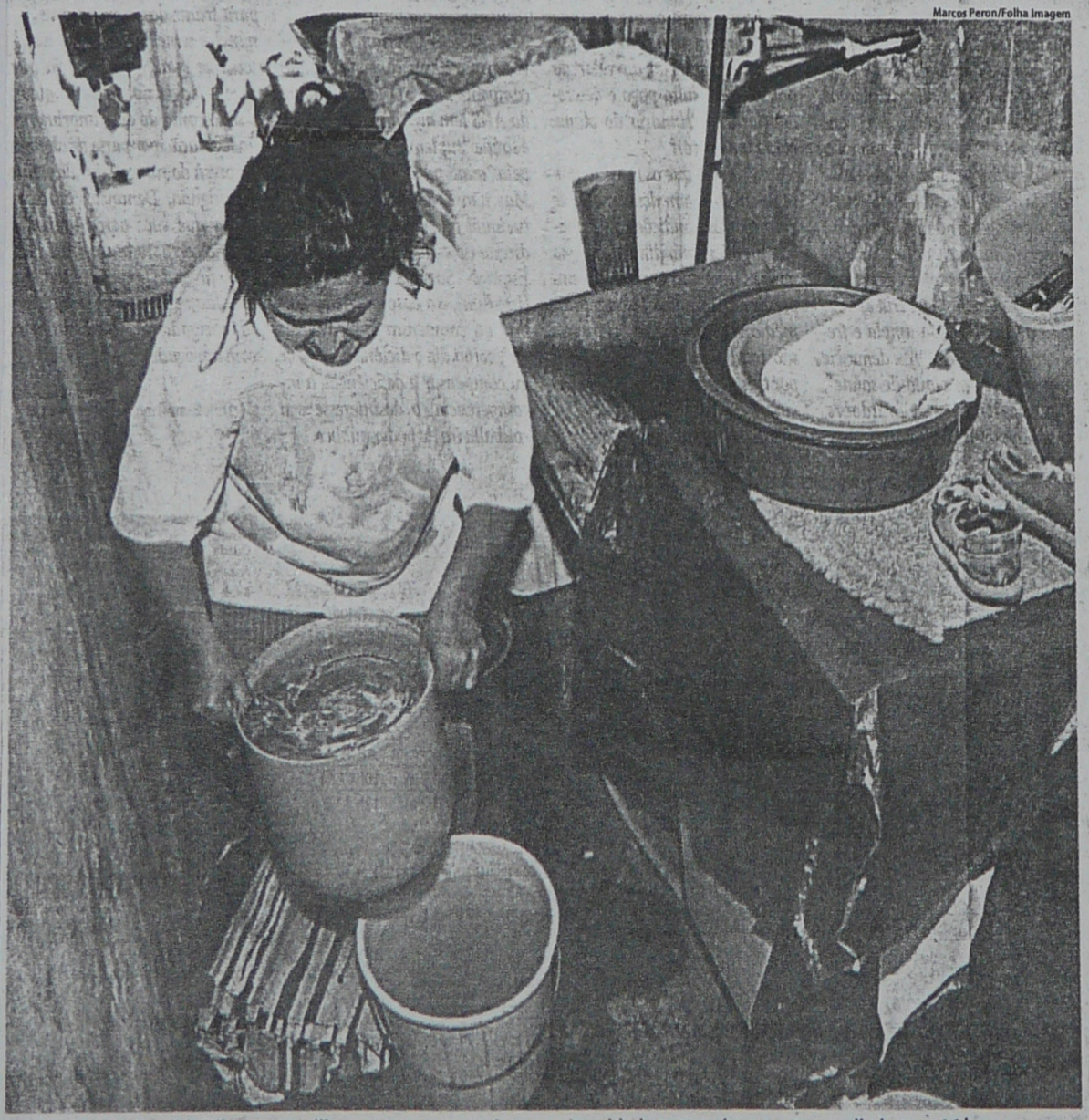

A dona-de-casa Ivanilde Silva com vasilhas para armazenar água, em Itu; cidade teve racionamento ampliado para 16 horas
ANA PAULA MARGARIDO EREE-LANCEPARAAFOLHACAMPINAS

O Saae (Serviço Autónomo de Água e Esgoto) de Itu (55 km de Campinas) decidiu ontem ampliar 0 racionamento de 10 horas para 16 horas em toda a cidade. 0 corte no fornecimento comeca às 6 he vai até as $22 \mathrm{~h}$ diariarnente. 0 prefeito de Itu, Leonel Salvaestado de emergência devido à crise no abastecimento de água que afeta a cidade há dois meses. 0 municipio tem 130 mil habitantes e pelo menos 32,5 mil (25\%) moradores, segundo o Saae, não têm caixa d'água em casa, dificultando 0 armazenamento durante as poucas horas em queháágua nas torneiras.

Segundo o diretor do Departamento Técnico do Saae, José Carlos Rodrigues, a cidade já está sob estado de emergência.

"O decreto de emergência do ano passado ainda nāo foi revogado", disse o diretor.

Segundo Rodrigues, o novo decreto traria medidas mais rígidas do que o do ano passado, tais como o racionamento da água usada para irrigaçāo na agricultura, a aplicação de multas de até $R \$ 6,38$ para quem for flagrado desperdicando água e a abertura de barr gens particulares.

0 volume de água tratada já diminuiu $40 \%$ desde o início da estiagem, iniciada no final de marco. O Saae trata 19 milhōes de litros por dia. Na época das chuvas, litros diariamente A dona-de-casa Ivanilde Rosa da Silva, 36 , disse que acorda às $5 \mathrm{~h}$ para lavar a roupa e, mesmo assim, guarda água em baldes para cozin

"Ontem a água veio de madrugada e acabou rapidinhon ${ }^{n}$, disse (leia texto nesta página).

Várzea Paulista

A Sabesp (Companhia de Saneamento Básico do Estado de São Paulo) deve iniciar hoje, em Várzea Paulista (78 km de Campinas), o sistema de rodízio no fornecimento deágua.

Segundo o gerente da Sabesp em Várzea, Augusto Cimatti, 12 bairrós serão afetados nos próximos 15 dias.

Pelo menos 32 mil pessoas podem ficar sem água na cidade.

Cimatti disse que vai tentar um acordo com a prefeitura para impor multas àqueles que desperdiçaremágua.

Em Sumaré ( $26 \mathrm{~km}$ de Campinas), cerca de 80 mil pessoas devem ficar sem água hoje por caus da manutenção da rede da CPFL Companhia Paulista de Força Luz).

0 corte de energia elétrica vai paralisar o bombeamento na represa do Marcelo e interromper 0 abastecimento de 19 bairros. A estiagem completou ontem 61 dias e não há perspectivas de chuas agricolas (acima de $70 \mathrm{~mm}$ em 30 dias) até outubro, segundo 0 Cepagri (Centro de Ensino e Pesquisa em Agricultura) da Unicamp (Universidade Estadual de Campinas). Campinas registrou ontem a temperatura mais baixa do ano (leia texto nesta página). 


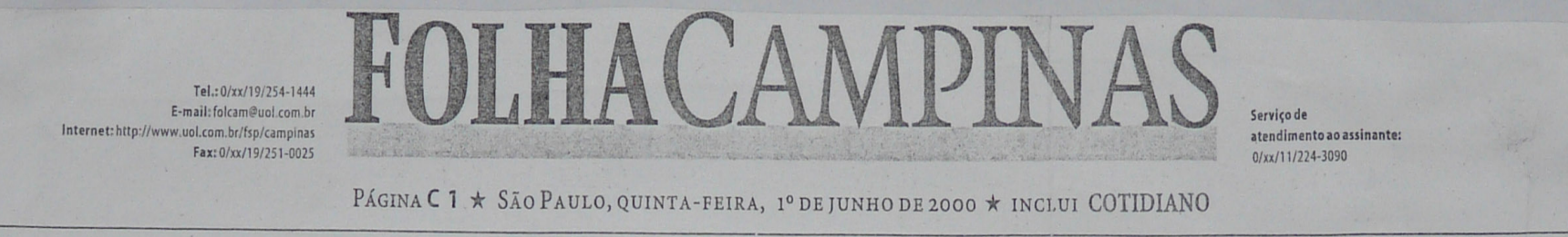

SECA Medida seráa partir da próxima segunda-feira para escolas municipais e poderá ser estendida para a rede estadual

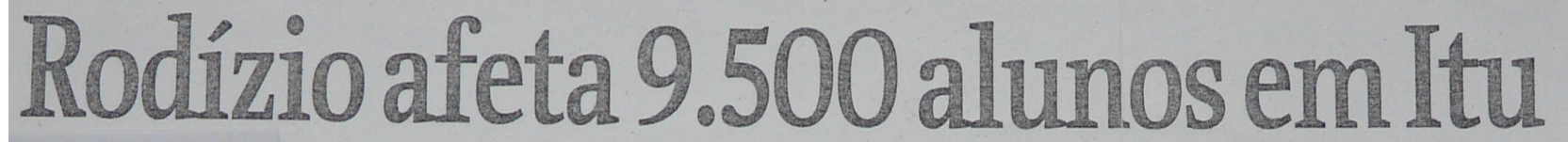

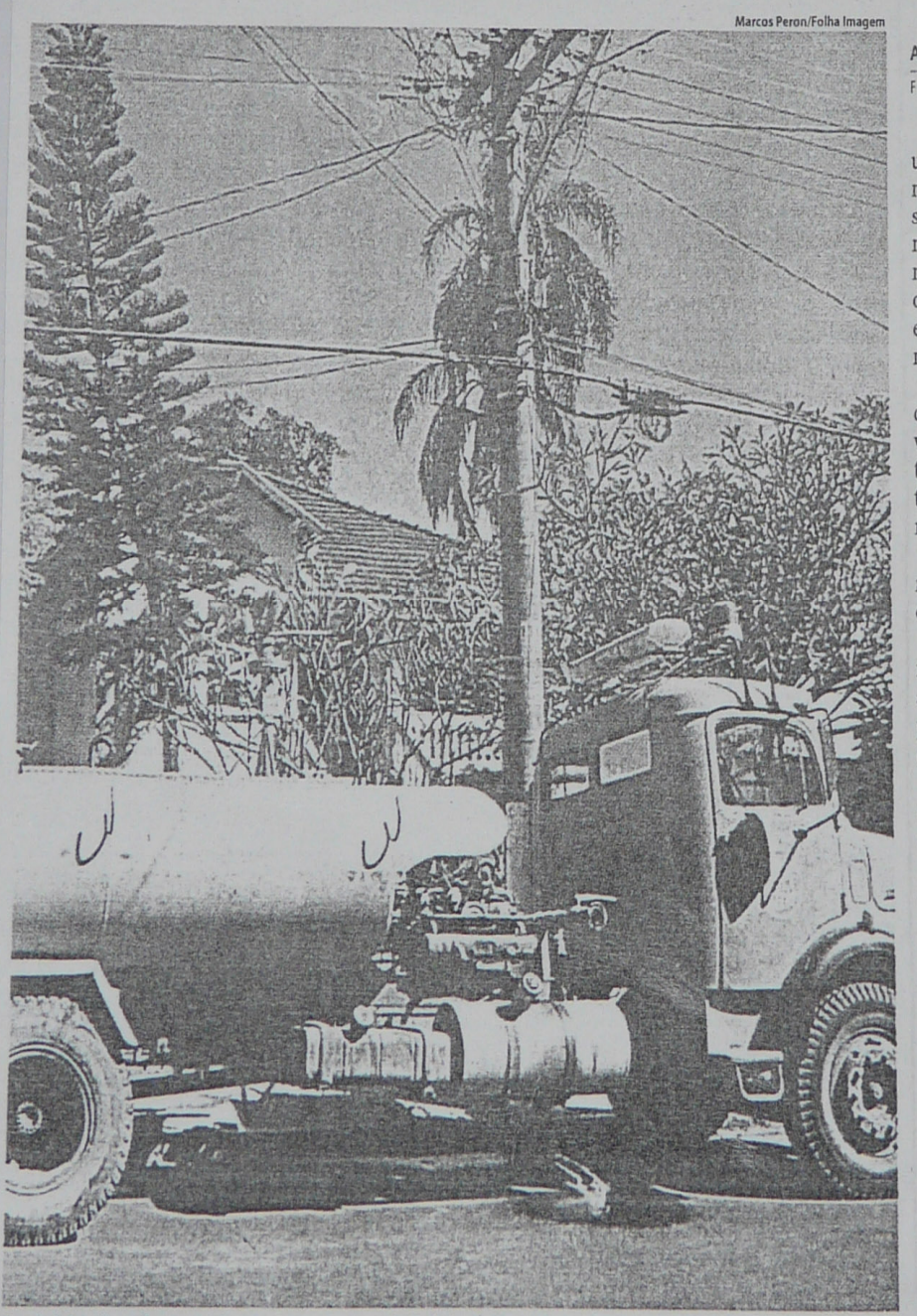

Caminhão-pipa abastece de água a Secretaria da Saúde de Itu; cidade enfrenta racionamento há 17 dias
ANA PAULA MARGARIDO REE-LANCE PARA AFOLHA CAMPINAS

A Prefeitura de Itu vai implantar um esquema de rodízio de aulas as escolas municipais a partir de gunda-feira, em ràzão da crise no abastecimento de água. Pelo menos 9.500 alunos serão afetados pela medida em 28 unidades escolares, segundo o prefeito Leonel Salvador (PMDB).

0 racionamento começou há 17 dias, Há quatro dias, o Saae (Servico Autônomo de Água e Esgoo) restringe of fornecimento a oito horas durante a madrugada para todos os moradores.

Itu tem 130 mil habitantes e pelo menos 32,5 mil não têm caixad'água, segundo o Saae.

A sugestão de alteracão de horários nas escolas municipais foi apresentada ontem ao prefeito pela secretária municipal da Educaçāo, Célia Regina Pires.

"A suspensão acontecerá em dias alternados na escolas de educação infantil", disse o prefeito.

Parte das escolas terá aulas três

dias por semana e outra parte, dois dias semanais. Segundo ele, nas très escolas de ensino fundamental e no supletivo haverá redução de carga horária de quatro horas para duas horas por dia. Nas creches e berçários, 0 atendimento será restrito às mães que moram longe do local de trabalho e näo têm com quem deixar os fithos. 0 fornecimento de água na escolas e hospitais é feito por meio de caminhōes-pipa.

Rede estadual

0 prefeito se reúne hoje com a dirigente-regional de ensino, $\mathrm{Ma}$ Zilda Cesarotto, para definir se medida será estendida para os 25,2 mil alunos das 23 escolas estaduais.

A suspensão das aulas será "Assa úlima alternativa", afirmouMariaZilda.

0 prefeito decretou estado de calamidade pública anteontem por causa da crise no abastecimento deágua.

A prefeitura já interrompeu 0 ornecimento de água para a irrigacão agrícola em 15 propriedades rurais localizadas acima dos reservatórios e pediu a abertura de barragens particulares.

Uma cópia do decreto foi enviada ontem à Defesa Civil de São Paulo e para a apreciação do governador Mário Covas (PSDB).

De acordo com a Defesa Civil, um agente regional deve ser enviado a Itu para avaliar os danos causados pela estiagem.

Só entāo, o governador deve homologar ou não o decreto.

A cidade está sob estado de emergência desde setembro do ano passado, quando o volume de água nos reservatórios caiu 70\%, segundo a assessoria de imprensa da prefeitura

De acordo com o prefeito, Itu depende do regime de chuvas.

A quantidade de chuva acumulada em marco deste ano é de 1,9 $\mathrm{mm}$ contra $34,6 \mathrm{~mm}$ do mesmo período do ano passado, segundo o índice pluviométrico (medidor de chuva) do Saae.

0 Saae trata atualmente $19 \mathrm{mi}-$ thōes de litros de água por dia, dos 47 milhöes tratados antes da estiagem, iniciada há dois meses. 


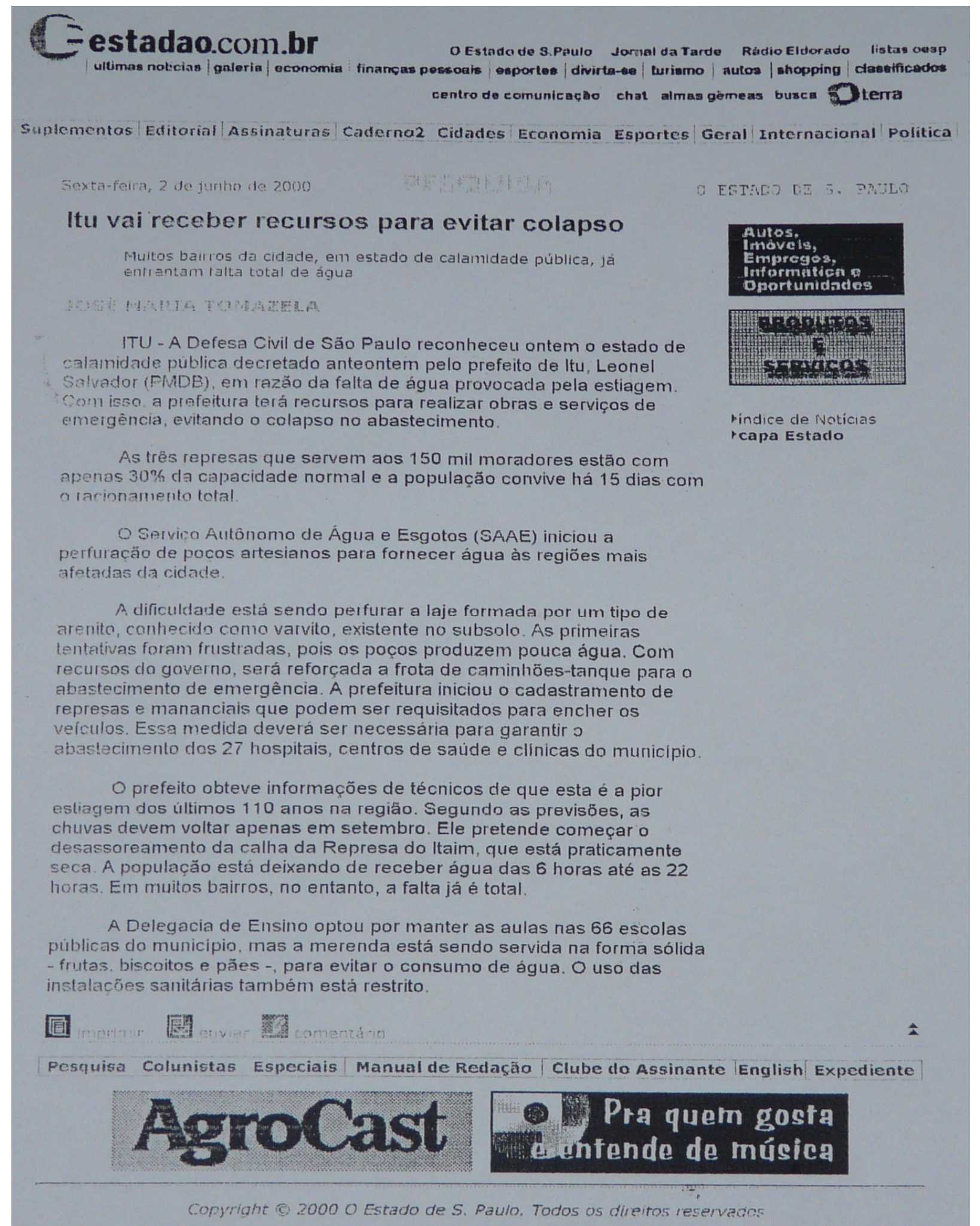




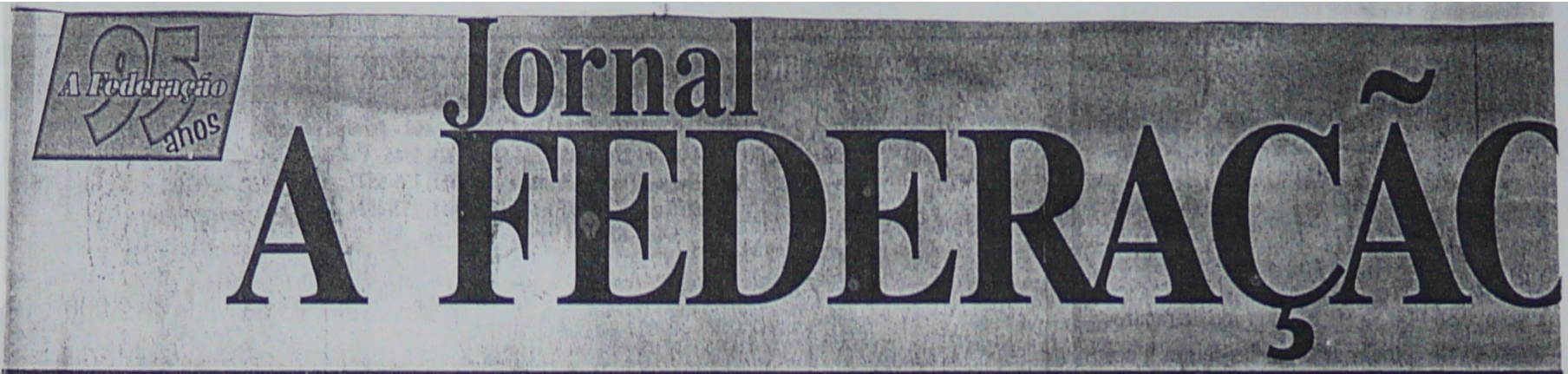

- Diretor Responsável: Ednan Mariano Leme da Costa ** Itu (SP), sábado, 03 de junho de 2000 - RS 1,50 - Ano XCV * Ediçäe

A vida dos ituanos vira um inferno

0 racionamento da água, que desta vez começou em maio, oleixa em polvorosa, principalmente, as donas-de-casa

Na página 2, em Eles disiseram..., trazemos um pouco daqu uilo que vem sendo a grita gerail na cidade, contra esse verda deiro flagelo sobre Itu.

Insurgem-se os políticos quanclo se responsabiliza as admir ıistrações nas últimas décadas. Mas é is: o que acontece. Itu ficou a mercê da imprevidência, nesse setor, por parte de gestores desprej arados, distraídos ou indiferente.

Um detalhe: a de retação de calamidade pública, num evento previsível e não cuidado a tempo, é a forma acabada de atestado público de incapacidade daqueles que se omitiram.

Pág. 2

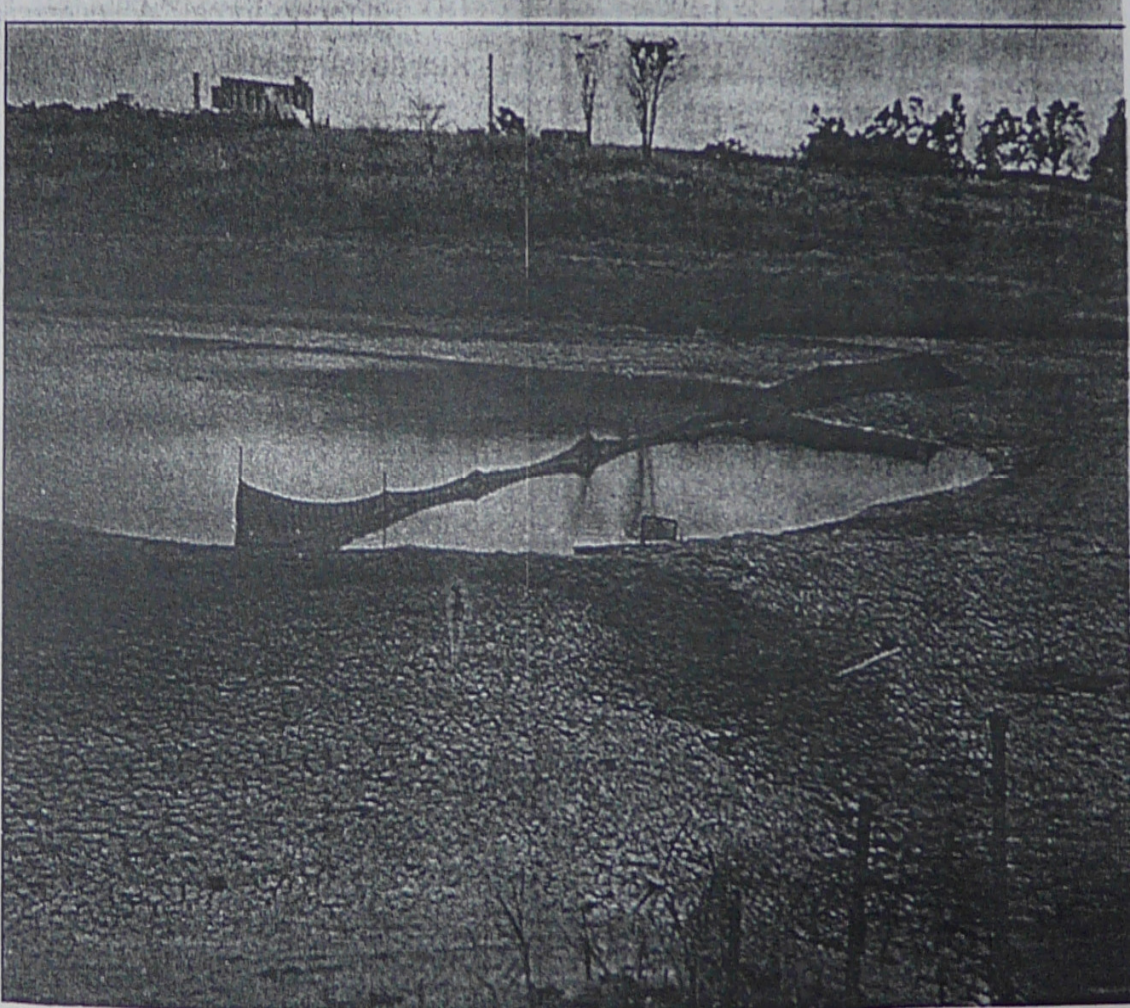




\section{Prefeitura de Itu confisca poços artesianos particulares}

Cidade esta em racionamento total de água e nivel de represas não pára de baixar

$$
\text { 95:30: }
$$

ITU - A prefeitura de Itu, a 98 quilobmetros de São Paulo, confiscou ontem dois poros antesianos particulares para amenizar a falta de água que afeta us 150 mil moradores da cidade. Os poços pertencem às empresas Curtume Kiriazi e Brinquedos Mimo e näo estavam sendo utilizados por seus proprietários. A água foi analisada antes de ser posta na
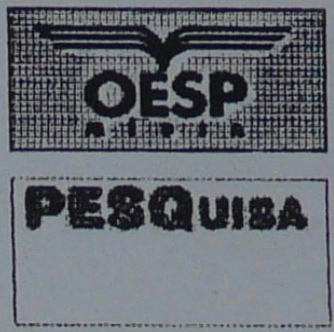

rindice de Naticias rcapa Estaxto rede.

Os 5.500 alunos das escolas municipais de educação infantil passaram ontem a ter aulas em dias alternados. Outros 4.200 estudantes dos cursos supletivos e de ensino fundamental tiveram o período escolar reduzido de cinco horas para duas horas e meia de aulas diárias.

A prefeitura reduziu também o período de funcionamento das creches. As crianças estão sendo dispensadas no início da tarde.

Calamidade - A cidade enfrenta há 18 dias o racionamento total de água e, desde quarta-feira, está em estado de calamidade pública. A situação das três represas usadas para o abastecimento piora a cada dia. As represas do Itaim e do Fubaleiro, que abastecem o centro e as regiões oeste e sul, estăo quase secas. A água está sendo usada apenas para abastecer escolas, clínicas e hospitais.

A água captada na Represa do Braiaiá esté sendo usada no esquema de racionamento. A água chega à torneiras durante a madrugada, obrigando as donas de casas a se levantarem para encher baldes e vasilhames.

A prefeitura de Itu pediu verba de $\mathrm{R} \$ 650$ mil ao governo do Estado para realizar obras de emergência. Os recursos devem ser usados em ações como o aumento na frota de caminhões-tanque e o aprofundamento do leito da Represa do Itaim. O dinheiro ainda não tinha sido liberado até ontem à tarde

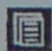

Pesquisa Colunistas Especiais / Manual de Redaçăo / Clube do Assinante English Expediente
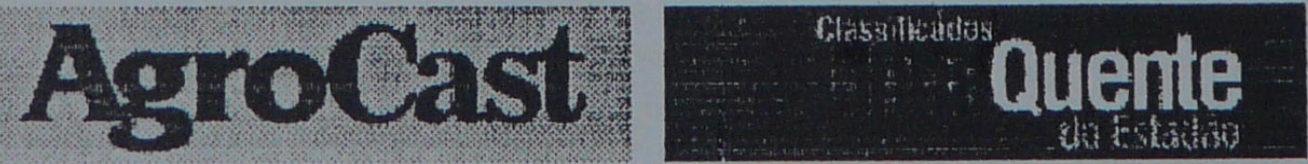

Copyright if 2000 O Estado de 5. Paulo. Todos os direitos reservados 
Jornal Folha de São Paulo

$27 / 06 / 2.000$

Terça-feira

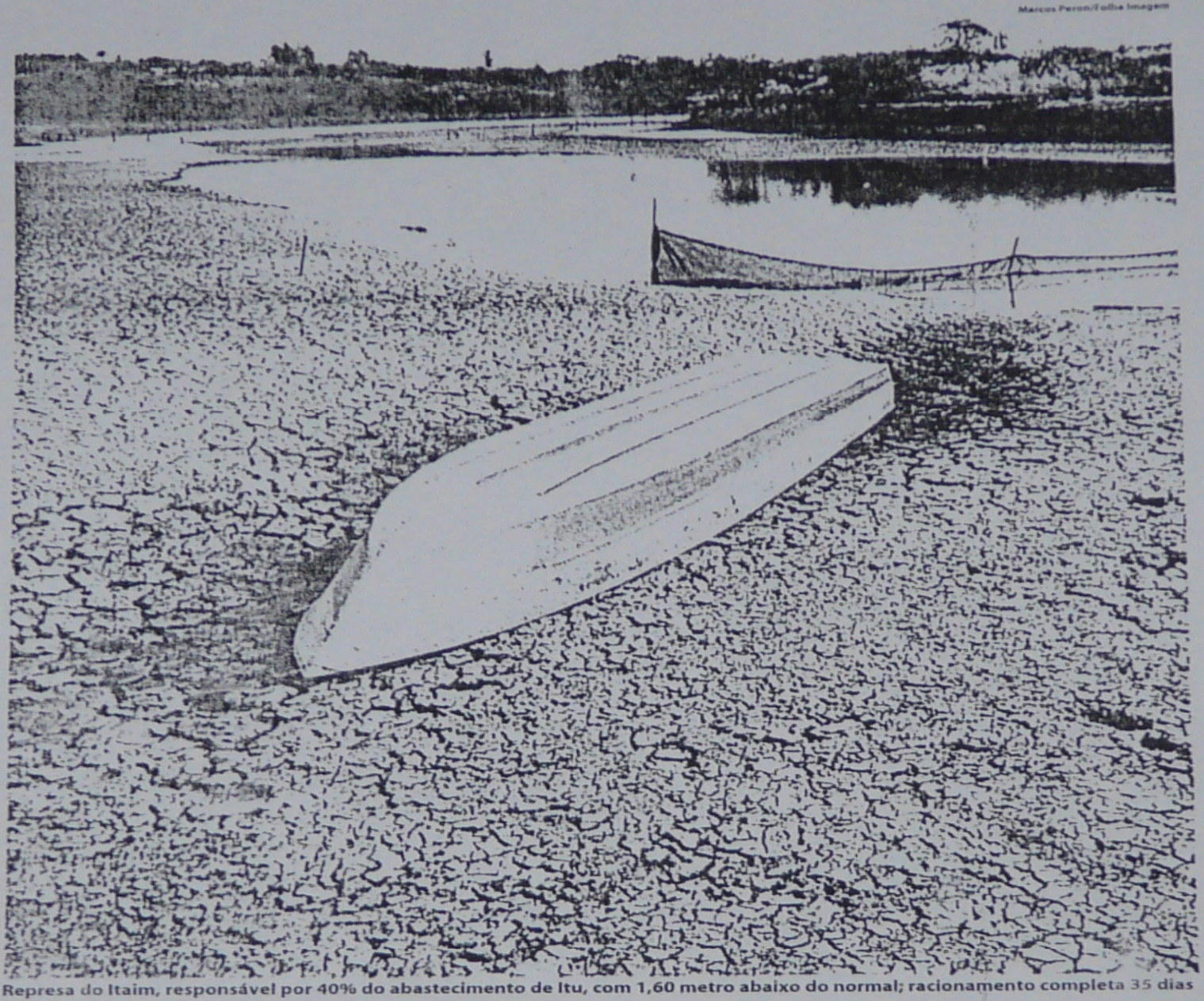

\section{Itu investe em obras de emergência}

FECE-LANCEPARAATOIHACAMPINAS

O municipio de Itu $(55 \mathrm{~km}$ de campinas) esta isvestindo em acrise de abastecimento que af a cidade $h \mathbf{i} 35$ dias.

Os 130 mil habitante da cidade enfrentam racionamento diário de 16 horas.

Sale (Serviço Autônomo de Agua e Esgoto) deve concluir em uma semana as obras de ampitaçâo da rede de captaçao de agua com o presidente da autarquia. Francisco Leite.

Antraciere. A oloracustoucetca de its $80 m i$ mil pagos pelo governo do Estado elo fornecimento de água ds esetaduais.

O Saae espera aumentar ovolume captado de 20 mil litros por hora para 70 mil litros por hora. captaçăo do rio Itaim Mirim. O aumento na captaça deve beneficiar peto menos 6.000 pes soas, que moram na regiáo leste. onde há bairros desabastecidos. A dona-de-casa Maria Aparecida Spina, 35, disse que acorda todos os dias as 4 h para encher baldes e am reservatorio de soolitros que comprou por causa do rodiifiacalru,", disse

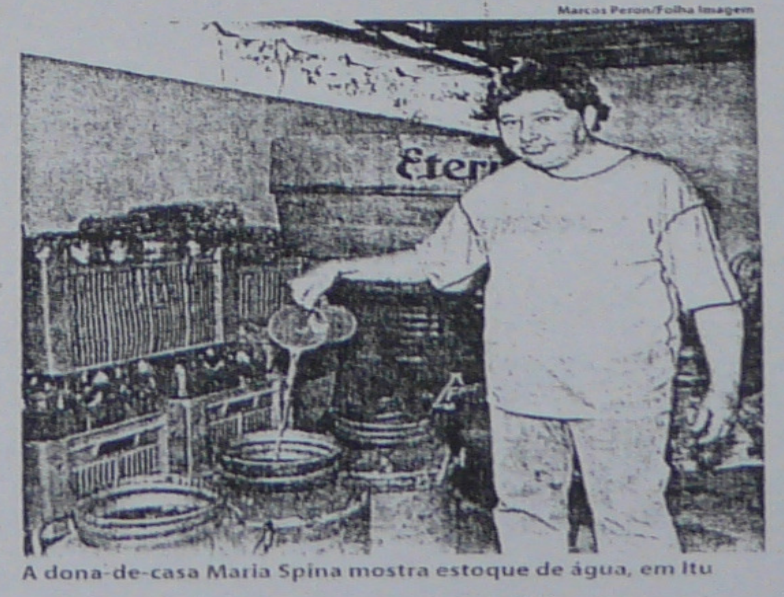




\section{ESTRACER Aumento no consumo amplia queda do nível dos reservatórios; estiagem completa 104 dias e atinge 130 mil}
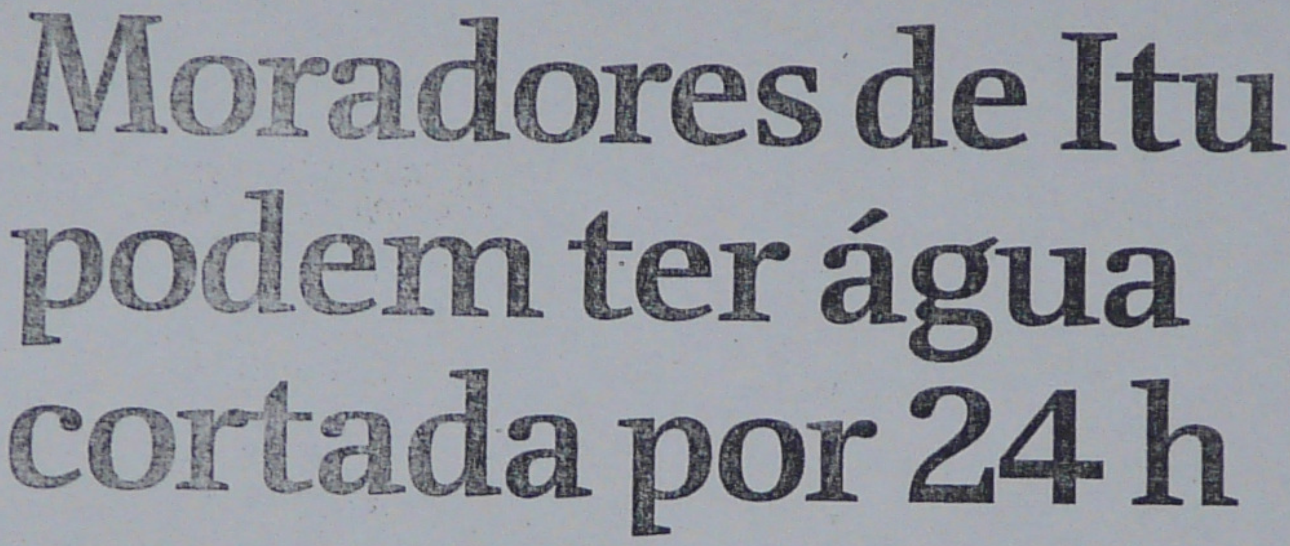

\section{ANA PAULA MARGARIDO}

FREE-LANCE PARA A FOLHACAMPINAS

O diretor do Saae (Serviço Autônomo de Água e Esgoto) de Itu (55 km de Campinas), Francisco Leite, disse ontem que estuda implantar um esquema de rodízio, que pode deixar a população sem água por 24 horas consecutivas em dias alternados.

Os 130 mil habitantes de Itu enfrentam um racionamento de 16 horas por dia há dois meses.

A medida pode ser adotada caso o nivel das represas que abastecem a cidade continue caindo.

Segundo Leite, mesmo durante o racionamento a população pode estar consumindo mais água, o que aumentou a queda do nível dos reservatórios em mais $5 \%$.
A estiagem completou ontem 104 dias na regiāo.

Há uma semana, o Saae deixa de tratar 950 mil litros de água por dia em razão da queda de mais $5 \%$ no nível dos reservatórios. O volume é suficiente para a abastecer 4.000 pessoas.

A Represa do Itaim está com o nível 2,70 metros abaixo do normal e a represa do São José está com 1,60 metro abaixo. As duas represas são responsáveis por $60 \%$ do abastecimento da cidade.

"Se o desequilíbrio aumentar, teremos de recorrer ao rodízio", disse Leite.

Para ele, a situação deve piorar se a queda nos níveis dos reservatórios chegar a $10 \%$.

Segundo Leite, a autarquia trata 18 milhões de litros por dia, con- tra os 19 milhōes que eram trata. dos no início do racionamento.

O volume tratado já é $50 \%$ me. nor que em época de chuva.

O Saae começou, na semana passada, as obras de ampliação da rede de captação de água do córrego Sāo José.

O Saae espera aumentar o volume captado de 20 mil litros por hora para $70 \mathrm{mil}$ litros por hora e beneficiar pelo menos 6.000 pessoas que moram na região leste.

A Câmara de Sumaré (26 km de Campinas) deve votar amanhã, em sessão extraordinária, projeto de lei elaborado que prevê a cobrança de multa para quem desperdiçar água. É a terceira vez que o projeto de multa é posto em votação na Câmara. Em 97 e 98 as propostas foram rejeitadas. 
Jornal Cruzeiro do Sul $15 / 07 / 2.000$

Sábado

\section{Racionamento de água já castiga Itu há dois meses}

estação de tratamenio do Jar dim Paraiso, para abastecer parte leste da cidade. O açude da Fazenda da Ponte também foi disponibllizado por seu proprietárío e deverá ajudar no abastecimento. fatiando apenas a colo cação da tubulaçāo, o que deve ocorrer até o final deste mês.

Quanto aos estudos da Unesp. de Botucatu, eles estāo em andamento e devern indicar onde podem ser perfurados poços artesianos. Essas açōes toram anuncladas no in icio do periodo de racionamento, em maio passado, e até o momento nāo foram efetivadas.

\section{$\mathbf{R} \$ 600 \mathrm{mil}$ jogados fora}

O projeto de concessão do Saae, protocolado na câmara no final do ano passado pelo prefeito Leonel Salvador (PMDB), foi por ele mesmo retirado há cerca de iuas semanas, já que enfraquecido politicamente, nāo contava com a maioria dos votos dos vereadores ituanos e optou por re tirá-lo da câmara.

Para a realização do projeto foram gastos RS $600 \mathrm{mil}$, pagos à Fundaçāo Getúlio Vargas, para demonstrar a viabilidade da concessão. Com esse dinheiro podería ser construida outra represa do tamanho do Itaim, com capaciclade de 200 milhōes de litros. $\mathrm{Com}$ a retirada do projeto da câmara. os Rs 600 mil foram prati capnente jogádos no lixo. , coin.

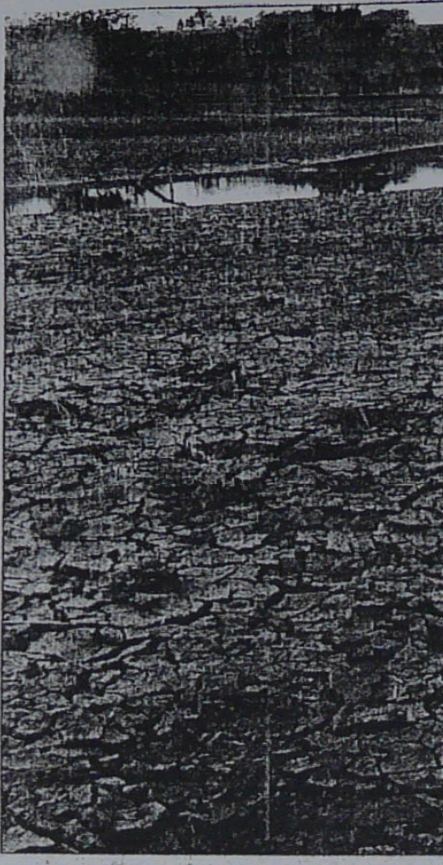

\section{Andréia Santos}

O racionamento de água que vem castigando a população de Itu completa dois meses hoje e como a situação dos mananciais é preocupante, o abastecimento continua comprometido e o tempo que as casas ficam receber âgua, que hoje é de $16 \mathrm{~h}$ por dia. pode aumentar. As represas que abastecem a cidade continuam operando com cerca de $15 \%$ da capacidade e o estado mais precário é da represa do Itaim, que mesmo funcionando apenas oito horas por dia não garante mais o abastecimento de água para cerca de $35 \%$ das residências ituanas e está sendo complementa da pela água vincia do bairro Rancho Grande. As açōes pre vistas para amenizar os proble mas de abastecimento de água ainda nāo foram oficializadas mas podem estar sendo efetivadas atê o final do mês.

De acordo com a cirretor técnico do Serviço Autônomo de Água e Esgoto (Saae), José Carlos Rodrigues, existe a possibilidade de aumento do horário de racionamento, que vem sendo estudado. "Durante os dois me ses tivemos duas chuvas que foram pequenas, mas garantiram o nivel das represas, agora esperamos que a chuva venha para podermos descartar o aumento do horárlo de racionamento. Caso nāo chova iremos ter que. rever o abastecimento, mas ain-

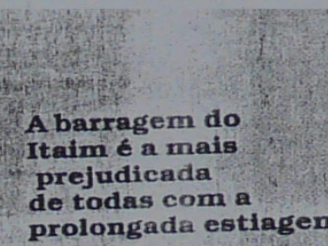

prolongada estlagem da nāo sabemos como proceder" afirmou Rodrigues.

Rodrigues adiantou que 0 projeto de desassoreamento do Itaim, para aumentar a capacidade de armazenamento de água, já foi enviado ao Departamento de Aguas e Energia Elétrica (Daee) e espera a ilberação deste para a sua efetivação. "Jâ achamos local apropriado para depositar a lama e também contamos com a boa vontade das cerámicas que pu-t rão utilizar o barro retirado da $r e$ presa", destacou o diretor

O Daee vem orfentando para a regularização de todas as repre sas da cidade laumento de capacidade) desde 1984 e quando a barragem do Itaim foi construída em 1990, o orgão sugeriu que ela já fosse regularizada mas o exprefeito Sérgio Prévidi (PMDB), optou por fazer a represa sem a regularização, o que deve ser efetivado somente no final do mês. apesar da situacāo calamítosa do municipio. Em 83, o então prefei to Lázaro José Piunti (que gover nou a cidade de 83 a 88 e de 93 a 96), já considerava a situaçào da falta de água como "calamitosa" mas pouco foi feito para evitar o grave problema atual.

Também estão previstas a utilização do córrego Itaim Mirim que deverá jogar na represa cerca de $15 \mathrm{mil} \mathrm{litros} \mathrm{de} \mathrm{água}$ por hora e do córrego Sāo José, cuja expectativa de vazâo é de 70 mil litros por hora e água deverá ser jogada diretamente na 


\section{Falta d'água gera reclamações pela cidade}

No rádio, pela manhã, prefeito falou em racionamento no município. À tarde, suspendeu a ação após pancadas de chuva

TIAGO KEESE

Itu-Na última quarta-feira, 0 diretor presidente do Saae (Servico Autônomo de Agua e Esgoto) de Itu, Maurício Dantas, concedeu uma entrevista ao Periscópio e afirmou que a falta de água em bairros da cidade nos últimos dias estava ocorrendo em virtude de questões técnicas e de manutenção na rede de distribuição de água em alguns pontos. Nos últimos dias, vários moradores têm ligado para 0 jornal reclamando da falta de água em suas residências.

0 presidente do Saae afirmou que, por enquanto, não havia problemas com falta de água na cidade: "Existiram nos últimos dias problemas na distribuição de água em Itu, mas foram por motivos operacionais. No momento, a cidade não sofre com falta de água", garantiu, acrescentando, entretanto, que havia a pre- ocupação com a escassez de chuva: "Não chove consideravelmente no município há 90 dias. Podemos dizer que já acendemos 0 sinal amarelo no Saae. Estamos em alerta", ressaltou.

Ontem pela manhã, em seu programa de rádio, o prefeito Herculano Junior chegou a falar sobre a situação, dizendo inclusive que 0 racionamento estava implantado no município. À tarde, a assessoria de imprensa do prefeito informou que o Saae estuda a possibilidade de iniciar o racionamento, mas que a medida ainda não entrou em vigor.

Nos últimos dias, dois problemas operacionais prejudicaram 0 sistema de distribuição de água em Itu, segundo Maurício Dantas. 0 primeiro foi no bairro Cidade Nova. A falta de energia na sexta-feira à noite da semana passada foi a responsável pela paralisação do serviço. " 0 corte de energia atrapalhou com- pletamente a distribuição de água na região do Cidade Nova. Porém, a situação já está se normalizando no bairro, e o serviçojá volta a funcionar normalmente", afirmou o presidente do Saae.

Outro ponto que ficou sem áfua já é considerado um problema crônico. Moradores da parte alta do Bairro Brasil reclamaram que ficaram sem água desde a manhã de domingo. Eles comentaram que a falta de água durante o dia em especial na Rua Sergipe, já virou rotina. A água chega apenas durante a noite. "Ficamos sem água desde domingo. As caixas d'água ficaram secas", comentou uma moradora.

0 Saae informou que precisou trocar uma bomb na fazenda Ponte Nova, 0 que pode ter causado falta de água no Bairro Brasil. "A Rua Sergipe sofre constantemente com falta de água pois está em um local onde é necessária muita pressão das bombas para que a água chegue nas casas", disse Dantas. Segundo ele a equipe do Saae acompanha de perto o nível das represas e mananciais, para estudar e tomar açōes para que não falte água na cidade. Para os próximos dias, há previsão de chuvas de intensidade leve, insignificante para aumentar o nível das represas, segundo ele.

A orientaçăo de Maurício Dantas para os moradores é que evitem gastos desnecessários de água: "A população precisa se conscientizar e poupar o máximo de água possível. 0 Saae faz campanhas para que as pessoas economizem água, porém, é necessária uma acão conjunta de economia. Pơr enquanto não há problemas com falta de água na cidade, mas evitar gastos desnecessários, como lavar carros e calçadas pode ajudar a afastar o risco", finalizou Dantas. 


\section{Após informar suspensão, Prefeitura confirma o começo do racionamento de água na cidade}

0 racionamento ocorrerá todos os dias, das $8 \mathrm{~h}$ às $17 \mathrm{~h}$, em todos os bairros da cidade, conforme comunicado distribuido pela Prefeitura

Itu - Depois de informar, na última sexta-feira à tarde, que 0 racionamento de água havia sido suspenso em toda a cidade, conforme noticia divulgada pelo Jornal Periscópio na edição de sábado, a Prefeitura de Itu distribuiu um comunicado à imprensa. ontem, explicando que a medida passou a vigorar por tempo indeterminado em todo 0 município.

Ontem pela manhä eno comeco da tarde, diversos leitores ligaram ao $\mathrm{Pe}$ riscópio dizendo que entraram em contato com o Saae e a informação que recebiam de funcionários era de que o jornal havia erradoe se equivocado e que não sabiam de onde havia saído tal informação. "Eles (Saae) me disseram, de forma bem mal educada e estúpida. pra ligar aí no jornal e reclamar, falando que 0 jornal fez besteira", relatou uma leitora. Um repórter do Periscópio ligou no Saae, passando-se por um cidadão, e confirmou o que os leitores relataram. $\mathrm{Na}$ verdade, a infor mação de que 0 racionamento estava suspenso por conta das pancadas de chuva na última sexta-feira partiu da própria Prefeitu$\mathrm{ra}$, que havia anunciado a medida pela manhã, por meio do próprio preféito Herculano Junior em seu programa semanal de rádio. No final de semana, panfletos anunciando 0 infcio do racionamento comecaram a ser distribuídos de casa em casa. A razão alegada para o início do racionamento é a estiagem prolongada que atinge toda a região. De acordo com o informativo, "a medida se faz necessária porque a cidade passa por um período com mais de 60 dias sem chuvas, 0 que ocasionou a diminuição da quantidade de água dos mananciais que alimentam 0 Sistema de Abastecimento de Agua de Itu, situação que se repete em várias outras cidades da região".

0 comunicado pede ainda a compreensão e a co- laboração da população, pois, apesar da queda de temperatura ocorrida nos Ǵltimos dias, 0 consumo de água continua muito elevado na cidade.

" 0 governo municipal tem tomado todas as providências possíveis para menizar o problema, mas ssume o compromisso de informar e alertar a populacão ituana de que 0 longo período de estiagem, considerando chuvas significativas, nāo traz outra solucão senão adotar 0 sistema de racionamento do abaste cimento em praticamente toda a cidade, a fim de ga. antir que, ao menos nos períodos em que a maioria das pessoas encontra-se em suas residências, possa uti. lizar a água", diz o comunicado da Prefeitura distri. buído ontem à imprensa

0 racionamento ocorrerá diariamente, das $8 \mathrm{~h}$ às $17 \mathrm{~h}$.

\section{Os bairros}

Confira a relação dos bairros atingidos pela medida: Jardim Aeroporto, Sãom Agarussi, Altos de Nova, parte do Bairro Brasil, Vila Bandeirantes, Condomínio Santo Antônio, Centro, Chácara Flora Bairro Chafariz, Vila Cleto, Jardim Convenção, Jardim Corazza, Bairro Cruz das Almas, Jardim Erídano Jardim do Estádio, Jardim Faculdade, Vila Gardiman Vila Gatti, Granja Bela Vis. a, Parque Residencia Guitti, Jardim Hélio Baptisti, Jardim das Rosas, Vila Leis, Bairro Liberdade, Vila Lucinda, Vila Militar Jardim Novo Itu, Jd. Padre bento, Vila Padre Bento Pq. Das Industrias, Pq. Jardim das Rosas, Parque In dustrial, Portal de Itu, Condomínio Portela, Vila Prudente de Moraes, Bairro Rancho Grande, Jardim Rancho Grande, Vila Roma Brasileira, Jardim Rosinha, Jardim Sāo José, Vila São José, Jardim São Jorge, Jardim São Judas Tadeu, Vila São Luiz, Vila São Vicente de Paulo, Jardim
Santa Laura Vila Santa ras Flórida Chácaras reuRosa, Jardim Santa Tere- nidas Ypê, Vila Esperança za, Vila Santa Terezinha, Estrada do Jacuhú, Vila Jardim Santana, Vila San. Fragnani, Vila Ianni, Resito Antonnio, Sitio Santā dencial Mayard, Parque Terezinha, Condomínio Nossa Senhora Aparecida Terras de São José, Vila Jardim Oliveira, Parque Nova Vila Vicentina, Vila Nossa Senhora Aparecida São Francisco, Jardim Vi- Parque Presidente Médice tória, Rodovia Waldomiro Bairro Progresso, CondomiCorrea de Camarco Jardim nio Santa Inés, Residencia das Industrias, Bairro Sete Quedas, Estrada de Pinheirinho, Vila Santa Porto Feliz, Vila Gabbai Rita, Loteamento Veneto, Chácaras Agrícolas BandeiVila São Paulo, Bairro Amé- rantes, Portal da Vila Rica rica, Bairro São Domingos, Bairro Barreto, Jardim Ri Residencial São Camilo, Araguaia, Residencia Residencial Villagios de Itá- Potiguara, Bairro Itaim lia, Jardim Santos Dumont, Jardim Bom Viver. Vila Jardim São Marcos, resi- Dona Tonica, Vila Mariah, dencial Maria Fernanda, Jardim dos Ipês e Jardim Residencial Itaim, Jardim Residencial Itaim 2 Paraíso I e II, Alto das Pal- Também estāo no meiras, Bairro Brasil (Par- esquema de racionamento te alta), Manqueiras de Itu, implantado pelo Saae todos Bairro Novo Itu (parte os oito bairros da regiâo do alta), Jardim das Paineiras, Pirapitingui: Cidade Nova Bairro Pedregulho, Cháca- Jardim Novo Mundo Vila ra Paraíso, Condomínio Martins, Portal do Eden Theodora, Canjieca, Condo- Jardim União, Jardim Eumínio Plaza Atheneé, Chá- ropa, Vila Vivendas e Vila caras Primavera, Jardim da Paz, porém, com racionaAlberto Gomes, Bairro Alto, mento de apenas seis hora Chácaras Carolina, Cháca- durante 0 dia. 
Saae anunciou que água faltaria das 7h às 18h, porém, em vários bairros as torneiras permanecem secas até a madrugada

\section{TIAGO KEESE} NATÁLIA DE CASTRO

Itu - Durante esta semana, a reportagem do Jornal Periscópio recebeu diversas reclamaçōes referentes ao racionamento de água na cidade. Praticamente todos os dias, moradores ligaram à redaçāo para reclamar, principalmente com relação ao fato do Saae ter anunciado que haveria falta d'água das $7 \mathrm{~h}$ às $18 \mathrm{~h}$, mas as tornelras permanecerem secas até altas horas da noite.

Na Vila Gatti, a água tem acabado às $8 \mathrm{~h}$, segundo uma moradora, e só volta às $21 \mathrm{~h}$, ficando mais de 12 horas sem água. Ela sugeriu ao Saae para se programar, e não dar esse corte repentino. "Eles esperaram a situação ficar crítica e deram esse corte louco. Se do não sobe até a parte alto já sabe que não vai chover, do bairro. Ele estava tencomeça a cortar aos poucos", disse. Ela comentou que menos horas por dia. A moradora denunciou também que há vizinhos na rua que, quando a água volta, nchem a piscina da casa: É uma total falta de consciência", afirmou.

Já os moradores da rua Monsenhor Luiz Otávio Bicudo, no Jardim $\mathrm{Pa}$ dre Bento, ficaram sem água de quinta para sextaeira, pois a água não vem com força suficiente para ubir até a caixa d'água. Nas ruas Pará e Belém, no airro Brasil, por volta das h já não há mais água. Ela só volta lá por meiatarde, segundo os moradores. Um morador da rua Pará disse que chegou a ficar dois dias seguidos sem água em casa, pois o líqui- podia, um mês antes, já co- tando entrar em contato sibilidade. "Ele disse que a meçar a cortar, mas por com o Saae para pedir um noite, $e$ às vezes até mais caminhão pipa que amenizasse a situação para ele e seus vizinhos.

Um morador do bairro Novo Itu também reclamou do racionamento, dizendo que a água em sua casa só chega depois da meia-noite. "E impossíve] que a água demore mais de seis horas para chegar em casa", disse. A pior situação está na Vila Ianni. Na rua Arthur Ianni, os moradores afirmaram que estāo há 10 dias sem água. Na rua, há deficientes físicos e uma mulher que terá filho nas próximas semanas. "Como que a mulher vai poder cuidar do recém-nascido sem água?", questionou um morador. A0 entrar em contato com 0 Saae pedindo para que um caminhão pipa fosse até 0 local, 0 atendente disse que não haveria posúnica maneira de vir um caminhão pipa aqui no bairro era se pedíssemos particular. 0 preco do serviço era de R\$100. E não tem condiçoees", relatou

Outra moradora do bairro disse que conversando com moradores mais antigos soube que o problema de água no local ocorre há mais de 15 anos. Nessa semana, ela já teve que comprar dois galōes de água para as necessidades básicas do dia a dia. Sua filha de quatro anos não foi à escola na última quarta-féra porque năo há uniformes limpos e ela não pôde tomar banho. Ela diz que toda vez que liga no Saae é mal atendida e lhe dão um número de protocolo, dizendo que não há previsão para visita de técnicos, já que há muitas reclamaçōes.

\section{Ex-presidente do Saae afirma} que racionamento continua

MÓNICA FUKUDA

Itu - "0 racionamento vai continuar até ter uma chuva forte 0 suficiente para reabastecer os mananciais", afirmou 0 ex-presidente do Saae (Serviço Autônomo de Áqua e Esgoto), Maurício Dantas. Na quinta-feira, a empresa Águas de Itu Exploração de Serviços de Água e Esgoto Ltda assumiu o comando do Saae. Mas o período de transição só termina em janeiro.

A concessionária terá mais agilidade de contratar em curto prazo mais caminhōes para abastecer as escolas pronto-socorro.

"Já estamos há dois me. ses e meio fazendo esta ransicăo, antes desta assinatura de hoje (quintafeira). A minha postura agora é acompanhar e dar apoio para eles fazerem o melhor trabalho a curto prazo. Mas năo vai ter descontinuidade de serviços", garantiu. Dantas também confirmou que o funcionamento $e$ serviços do Saae continuam normais. Ontem, a empresa distribui um folheto pela cidade explicando que sua prioridade é "enfrentar essa situaçāo e trabalhar para regularizar a oferta de água" 


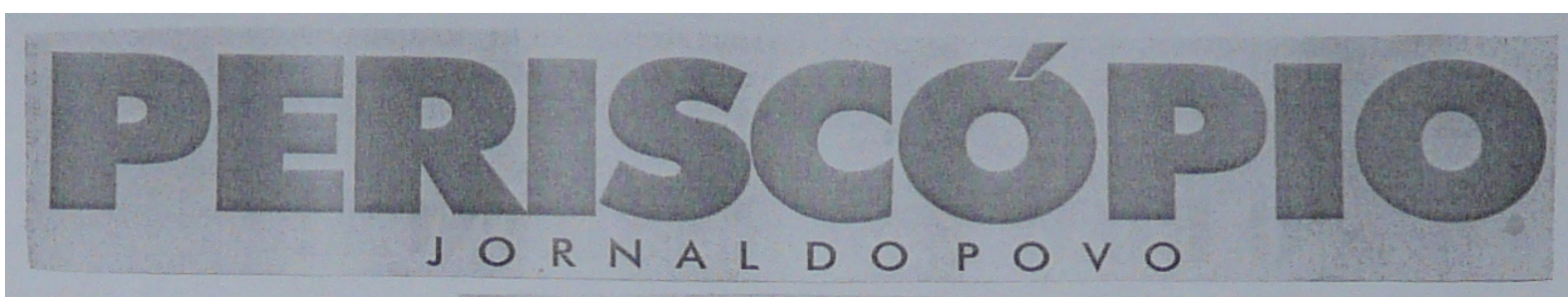

Sexta/sábado $\cdot 12 / 13$ de Outubro $\cdot 2007$

\section{Situação dla falta de água piora em Itu}

Moradores pedem soluções emergenciais para resolver o grave problema

NATÁLIA DE CASTRO

TIAGO KEESE

Itu - A população ituana continua sofrendo com a falta de água na cidade. Nesta semana, a situação piorou ainda mais. A cada dia que passa, está demorando mais para voltar a água. Em alguns bairros, não está chegando em nenhum momento do dia. Há casos em que ruas estão há quase uma semana sem água nas torneiras.

Uma moradora da rua Sergipe, no bairro Brasil, denunciou à reportagem do Jornal Periscópio que há uma semana ela está sem água, pois, por morar numa parte alta do bairro, a água não tem "forca" para subir até a caixa d'água. Ela diz que há 10 anos o bairro sofre com esse problema. "Quero saber o que será feito emergencialmente, seja pelo Saae ou pela empresa (Aguas de Itu). A população não pode esperar essa transição. Algo tem que ser feito", disse.

Os moradores da parte alta do Novo Itu, mais precisamente da rua Joaquim Galvão de França Pacheco, também estão sem água há bastante tempo. Lá, a água chega das $3 \mathrm{~h}$ às $6 \mathrm{~h}$. "A água vem durante pouco tempo, insuficiente para encher a caixa d’água. Nós, da parte alta, estamos sofrendo", disse um morador. Os moradores do Parque Jardim das Rosas são outros que reclamaram bastante nos últimos dias. $\mathrm{Na}$ noite de terça para quarta-feira a água não chegou até as caixas d'água das casas. Uma moradora ligou no Saae e foi informada que a água voltaria apenas nesta sexta-feira. "No bairro São Camilo a água chega às $20 \mathrm{~h}$ e pára às $8 \mathrm{~h}$. Por que existe essa diferença entre os bairros?", questiona a moradora. Ela reclama da falta de informaçōes do Saae, que não avisa quando o abastecimento será cortado para que os moradores se programem. "Ou abastece toda a cidade ou corta tudo de uma vez", disse. Um morador da rua das Tulipas, no Jardim das Rosas, também reclamou do atendimento no Saae. Ele disse que tentou ligar diversas vezes e ninguém atendia ou então o telefone dava ocupado.

Quando ele conseguiu conversar com uma funcionária, a mesma informou que só sabia que havia faltado água durante a noite, pois várias pessoas da Vila Roma, Jardim das Rosas e Parque Jardim das Rosas reclamaram. "Ela me disse que o problema tinha sido uma bomba e não deu nenhum prazo para que a situação fosse regularizada. Isso significa que ela sabia do problema", disse o morador.

Na rua Mônaco, na Vila Roma, próximo à Escola Pery, desde segundafeira não há água. "A água estava vindo das $3 \mathrm{~h}$ às $6 \mathrm{~h}$. Não tem como encher a caixa", disse uma moradora.

Leni de Fátima Teixeira, moradora da Vila Leis ligou no Saae e foi informada de que para acabar o racionamento a unica solucão é chover. "O que as cidades próximas de Itu, como Salto, Porto Feliz e Cabreúva, têm de diferente?", questiona.

$$
\text { Na rua Maestro João }
$$

Batista Macedo, no Jardim Padre Bento, não há água desde quarta-feira. Uma moradora ficou revoltada: "Eu tenho crianças e idosos em casa. Não temos uma gota de água, mas vamos ter que pagar a conta no mês que vem", afirmou. Ela também comentou que muitas pessoas que moram nas proximidades nāo possuem caixas d'água e estão sofrendo ainda mais com o racionamento. "Devia ter dado um desconto para nós. Eles não estão realizando o serviço", opinou a moradora.

Ontem à noite, uma diretora da entidade Casa de Emaús, que cuida de moradores de rua de Itu. entrou em contato com o JP dizendo que estava há 48 horas sem água. Hoje (ontem) não vai nem ter janta, porque não temos água para fazer a comida", disse.

\section{Desperdício}

Apesar da situação, algumas pessoas parecem năo se importar muito. Uma moradora do Residencial Itaim disse que flagrou, na manhã de ontem, um homem lavando a calcada de casa e um carro. Ela acha um "absurdo esse desperdício". "Eu economizo em casa para cuidar de meus três filhos e tem gente que nem liga. É um desrespeito com a cidade", disse. 


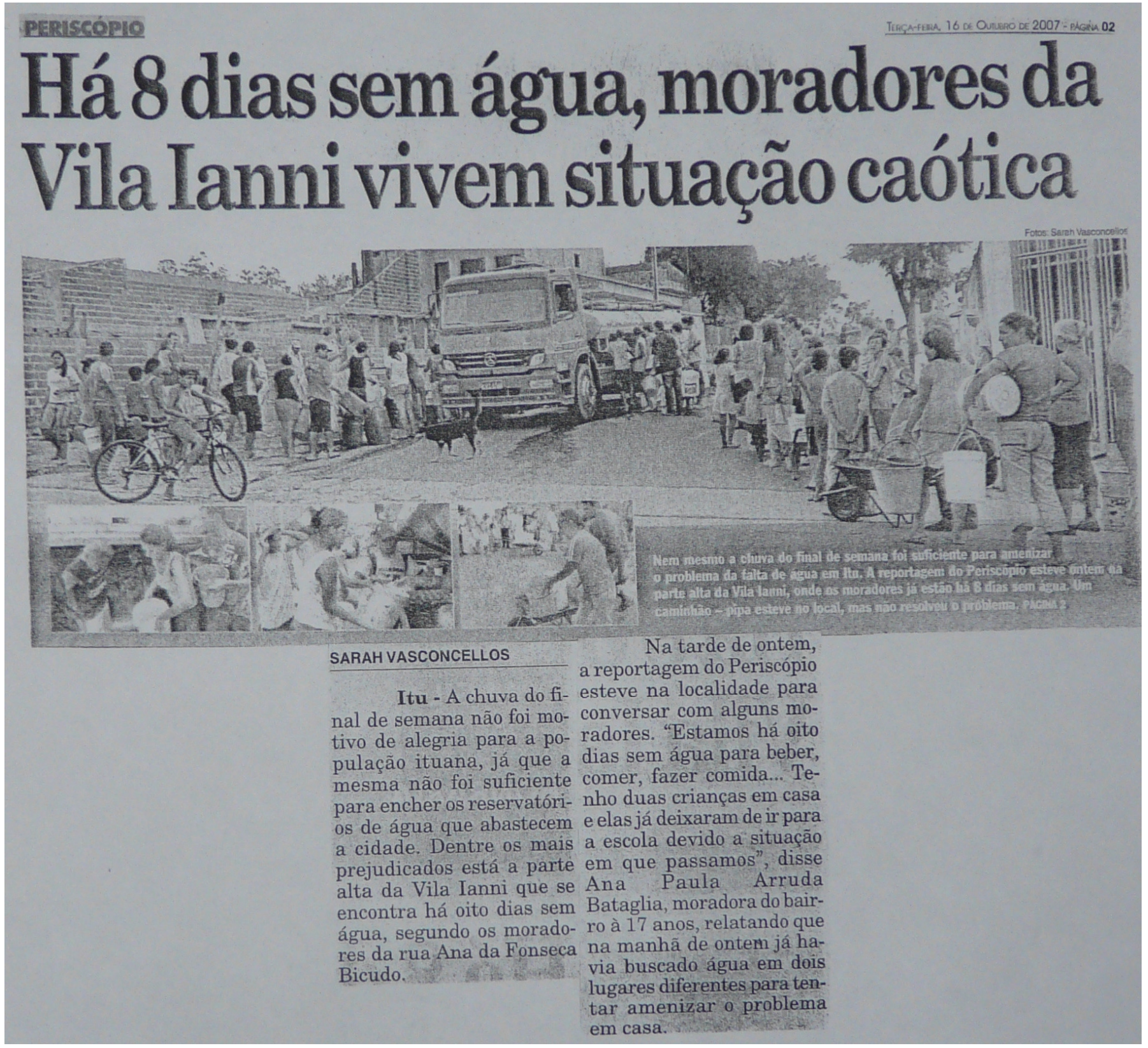



socioeconômicos no município de Itu-SP. 